\title{
Sufism and the Perfect Human
}

Studying the history of the notion of the 'Perfect Human' (al-insān al-kāmil), this book investigates a key idea in the history of Sufism. First discussed by Ibn 'Arabī and later treated in greater depth by al-Jīlī, the idea left its mark on later Islamic mystical, metaphysical, and political thought, from North Africa to Southeast Asia, up until modern times.

The research tells the story of the development of that idea from Ibn 'Arabì to al-Jîlī and beyond. It does so through a thematic study, based on close reading of primary sources in Arabic and Persian, of the key elements of the idea, including the idea that the Perfect Human is a locus of divine manifestation (mazhar), the concept of the 'Pole' (quț) and the 'Muhammadan Reality' (al-haqiqah alMuhammadiyyah), and the identity of the Perfect Human. By setting the work of al-Jîli against the background of earlier Ibn 'Arabian treatments of the idea, it demonstrates that al-Jīlī took the idea of the Perfect Human in several new directions, with major consequences for how the Prophet Muhammad - the archetypal Perfect Human - was viewed in later Islamic thought.

Introducing readers to the key Sufi idea of the Perfect Human (al-insān al-kämil), this volume will be of interest to scholars and students interested in Sufism, Islam, religion and philosophy.

Fitzroy Morrissey is an Examination Fellow of All Souls College, Oxford. He researches and teaches the intellectual and religious history of the Islamic world in the medieval and modern periods. Previously the co-author of Iran: Persia: Ancient \& Modern (2016), and the recipient of a DPhil in Oriental Studies at the University of Oxford (2018), this is his first specialist book. 


\section{Routledge Sufi Series \\ General Editor: Ian Richard Netton \\ Professor of Islamic Studies, University of Exeter}

The Routledge Sufi Series provides short introductions to a variety of facets of the subject, which are accessible both to the general reader and the student and scholar in the field. Each book will be either a synthesis of existing knowledge or a distinct contribution to, and extension of, knowledge of the particular topic. The two major underlying principles of the Series are sound scholarship and readability.

19 Sufism and Jewish-Muslim Relations

The Derekh Avraham Order

Yafiah Katherine Randall

20 Practicing Sufism

Sufi Politics and Performance in Africa

Edited by Abdelmajid Hannoum

21 Awhad al-Dīn Kirmānī and the Controversy of the Sufi Gaze Lloyd Ridgeon

22 Sufism in Ottoman Egypt

Circulation, Renewal and Authority in the

Seventeenth and Eighteenth Centuries

Rachida Chih

23 Perspectives on Early Islamic Mysticism

The World of al-Hakīm al-Tirmidhī and his Contemporaries

Sara Sviri

\section{Sufism and the Perfect Human}

From Ibn 'Arabī to al-Jīlī

Fitzroy Morrissey

For more information about this series, please visit: www.routledge.com/ middleeaststudies/series/SE0491 


\section{Sufism and the Perfect Human}

From Ibn 'Arabī to al-Jî̀ī

Fitzroy Morrissey

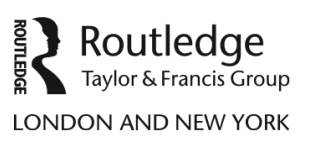


First published 2020

by Routledge

2 Park Square, Milton Park, Abingdon, Oxon OX14 4RN

and by Routledge

52 Vanderbilt Avenue, New York, NY 10017

Routledge is an imprint of the Taylor \& Francis Group, an informa business

(C) 2020 Fitzroy Morrissey

The right of Fitzroy Morrissey to be identified as author of this work has been asserted by him in accordance with sections 77 and 78 of the Copyright, Designs and Patents Act 1988.

All rights reserved. No part of this book may be reprinted or reproduced or utilised in any form or by any electronic, mechanical, or other means, now known or hereafter invented, including photocopying and recording, or in any information storage or retrieval system, without permission in writing from the publishers.

Trademark notice: Product or corporate names may be trademarks or registered trademarks, and are used only for identification and explanation without intent to infringe.

British Library Cataloguing-in-Publication Data

A catalogue record for this book is available from the British Library

Library of Congress Cataloging-in-Publication Data

A catalog record for this book has been requested

ISBN: 978-0-367-42672-9 (hbk)

ISBN: 978-1-003-00333-5 (ebk)

Typeset in Times New Roman

by Wearset Ltd, Boldon, Tyne and Wear 


\section{Contents}

\section{PART I}

Al-Jīlī's life and thought

1 Al-J̄̄lin’s life and work

2 Al-J̄̄ll̄’s Sufi metaphysics

\section{PART II}

3 A 'synthetic being': the Perfect Human as locus of divine manifestation and a microcosm

4 The Pole

5 The Muhammadan Reality 97

6 The identity of the Perfect Human 117 


\section{Acknowledgements}

All of my work on Islamic thought owes much to the guidance of Ron Nettler. Ron is the ideal mentor, and I cannot thank him enough for his insight, generosity, and kindness over the years. I owe a lot, as well, to my other teachers at the Oriental Institute in Oxford, in particular Nadia Jamil, Christopher Melchert, Nicolai Sinai, Geert Jan van Gelder, and Dominic Brookshaw. Conversations with Ufuk Öztürk, Haroon Shirwani (my original mentor in all things Arabic and Islamic), Stephen Hirtenstein, and Azfar Moin have enriched my understanding of Sufism and other areas of Islamic Studies. I thank too the Warden and Fellows of All Souls College, Oxford, for electing me to the fellowship that enabled me to write this book, and in particular to my academic advisor at the College, Noel Malcolm, for his interest in and support for my work. It has been a pleasure to work with Joe Whiting and Titanilla Panczel from Routledge; I thank them and Ian Netton for believing in the book, and Sally Quinn for her excellent work on the copy-editing of the typescript. My family and friends have been a source of constant support and inspiration. In writing this book, as in all that I do, I have been guided and sustained by the kindness, intelligence, and love of my wife, Dyedra. 


\section{Introduction}

The idea of the 'Perfect Human' (al-insān al-kämil) is one of the most important ideas in the history of Sufism. Indeed, given the centrality of Sufism within Islamic thought and piety, particularly prior to modern times, it can be deemed a significant idea in the history of Islam as a whole. General works on the history and culture of Islam and the Arabs often make at least passing reference to the idea. Most often, they connect the idea to the names of two medieval Sufi thinkers, namely, the extremely influential - and often controversial - Andalusian Sufi metaphysical thinker Ibn 'Arabī (d. CE 1240), and his later interpreter, 'Abd al-Karīm al-Jīli (d. 1408). Thus Albert Hourani informs the reader of his popular History of the Arab Peoples (1991), "The idea of the 'Perfect Man' (al-insan alkamil) put forward by Ibn 'Arabi was carried further by one of his followers, al-Jili (d. c. 1428)." A more recent and also influential work, the late Shahab Ahmed's What is Islam? The Importance of Being Islamic (2016), similarly describes al-J̄ili as "the elaborator from Muhyi al-Dīn Ibn 'Arabī (1165-1240), possibly the most influential Sufi in history, of the transfiguring Sufi concept of the 'Perfect Human' (al-insān al-kāmil)".

These scholars are not wrong to draw attention to the idea of the Perfect Human as a significant one in the history of Sufi thought. Nor are they mistaken to suggest that its origins, as a Sufi technical term and concept, lie in the works of Ibn 'Arabī, or that Ibn 'Arabī's treatment of the idea was taken on and developed by al-Jîlī. Nevertheless, while Ibn 'Arabī's idea of the Perfect Human has been treated in several modern studies, little attention has in fact been given to the precise nature and specific qualities of al-Jilil's treatment of the idea. As such, we have little idea of the history of the idea of the Perfect Human in the two centuries between Ibn 'Arabī and al-Jīlì, or of the exact nature of the latter's 'development' of this Ibn 'Arabian idea. The distinctive elements of al-Jililis idea of the Perfect Human, in other words, have largely been overlooked or forgotten, and his thought has instead been blurred into a common Ibn 'Arabian or 'Akbarian' tradition. ${ }^{3}$ It is the goal of this book, then, to unravel the distinctive qualities of al-Jîli's treatment of the idea of the Perfect Human, and of his thought more generally, and in so doing to tell the history of the idea of the Perfect Human.

'Abd al-Karīm al-Jīli can justifiably be regarded as one of the most important Sufi theorists of the medieval Islamic intellectual tradition. His major work, 


\section{Introduction}

al-Insān al-kāmil fì ma 'rifat al-awākhir wa-al-awà'il (The Perfect Human in the Knowledge of the Last and First Things), ${ }^{4}$ is a key text in the Sufi metaphysical tradition associated with Ibn 'Arabī, probably the most important Sufi thinker of any age. Written in Yemen at the beginning of the fifteenth century, al-Jîlī's magnum opus has been read by Sufis from West Africa and the Maghreb to Southeast Asia, passing through the Arabic, Persian, and Turkish speaking regions, up to modern times. Yet, despite this historical significance, both al-Jīli and his key text are little known today, either in the West or the Muslim world. In the case of the latter, this is perhaps due in part to a general waning in the popularity and acceptability of Sufism, particularly of the more theoretical, metaphysical kind represented by al-Insān al-kāmil and Ibn 'Arabian works more generally. As for the modern West, our ignorance of al-Jîli is a consequence both of a general lack of awareness of the medieval Islamic intellectual and religious traditions, and of an absence of translations (particularly into English) and scholarly studies of al-Jīlî̀’s work. Relatively little progress has been made in this regard since R.A. Nicholson's pioneering 1921 descriptive overview of al-Insān al-kāmil, ${ }^{5}$ and Titus Burckhardt's 1952 French translation of extracts from the first half of the book. ${ }^{6}$

To attempt to fill this gap, the present book offers the first extended study in English of al-Insān al-kāmil; indeed, I believe it is the first monograph treatment of al-Jīlì's thought in any European language. Specifically, this book focuses on al-Jîlī's treatment of the idea for which he became famous and which gives his major work its title: the Perfect Human. According to one of the leading Arab scholars of the Ibn "Arabian intellectual tradition, al-Jîli is "the specialist (șạhib al-ikhtișās), in the history of Islamic mysticism, on this topic". 7 That the idea is indeed the central focus of al-Jîlì's writing is indicated not only by the title of his most important work, ${ }^{8}$ but also by his statement in chapter 60 of that work, which is specifically devoted to the idea of the Perfect Human: "This chapter is the basis ('umdah) of the [other] chapters of this book; indeed, the whole book, from beginning to end, is a commentary (sharh) on this chapter." In light of this, as well as the aforementioned neglect of the distinctive features of al-Jilin's treatment of the idea, it makes sense to focus this, one of the very first book-length studies of al-Jîlin's thought, on his treatment of the idea of the Perfect Human. ${ }^{10}$

My discussion of al-Jîlī's treatment of the idea of the Perfect Man is thematic, meaning that I break down the idea into its constituent parts, presenting and analysing the key passages from al-Insān al-kāmil in which he treats those different elements of the idea. Moreover, I set al-Jīlin's treatment of these different key elements of the idea of the Perfect Human within the context of:

1 his broader Sufi metaphysics, which I set out at the beginning of the book, based on my reading of al-Insān al-kāmil as a whole;

2 earlier treatments of the various key aspects of the idea by the leading representatives of the Ibn 'Arabian tradition, beginning with Ibn 'Arabī himself and passing through the various representatives of what I call the Qūnawi tradition, i.e. the intellectual chain of transmission issuing from Ibn 'Arabī's son-in-law, leading student and successor (khalīfah), Șadr al-Dīn al-Qūnawī (d. 1274). ${ }^{11}$ 
I cite passages from the major texts of this tradition, beginning with Ibn 'Arabī's two great works, the massive and encyclopaedic al-Futühät al-makkiyyah (The Meccan Revelations) and the more concentrated and concise and more purely metaphysical Fușuṣ al-hikam (The Gemstones of Wisdom), and passing through the key works of the Qūnawi tradition, including, to take only the books cited most often here, al-Qūnawī's own major works, Miftāh ghayb al-jam 'wa-al-wujūd (The Key to the Unseen Realm of Synthesis and Existence) and I'jāz al-bayān fi tafsìr umm al-Qur'ān (The Inimitability of Expression in the Exegesis of the Mother of the Qur'an), al-Qūnawī's student Sa'd al-Dīn al-Farghānī's (d. 1300) Ibn 'Arabian commentary on Ibn al-Fāriḍ's famous Tã'iyyah poem, and the commentaries on the Fuṣuṣ by 'Abd al-Razzāq al-Qāshānī (d. 1329) and his student Dāwūd al-Qayșarī (d. 1350/1351). Since these texts are not very widely known or accessible, I quote directly from them, generally allowing them to speak for themselves.

This contextualisation allows us to build up a picture not only of how al-Jîli conceived of the idea of the Perfect Human, but also of what makes his conception both similar to and distinct from other treatments of the idea. As we shall see, while al-Jîli certainly was an adherent of the Ibn 'Arabian tradition, there is much that is distinctive about his idea of the Perfect Human. In this way, the book seeks to problematise the tendency to view the idea of the Perfect Human as a perennially fixed idea, and the Ibn 'Arabian Sufi metaphysical tradition and Sufi thought itself - more broadly as a homogeneous and unchanging worldview. This book is therefore written from the standpoint of the history of ideas, rather than from within that Sufi metaphysical tradition or as part of an attempt to uncover perennial truths located in Sufi texts. ${ }^{12}$

The term 'Perfect Human' is an arresting one, and one which raises a number of important questions. In the following pages, for instance, we shall consider what makes the Perfect Human 'perfect'. This will involve considering the Perfect Human's metaphysical status as well as his or her human nature and powers within this world. After introducing al-Jîlī's life and times and his general Sufi metaphysics in Chapters 1 and 2, our focus in Chapter 3 will be on the idea of the Perfect Human as a 'synthetic being', that is, as someone who is both a locus of divine manifestation, on the one hand, and a microcosm of the cosmos, on the other. The implications of these ideas for the Perfect Human's this-worldly nature will also be explored, through a focused discussion of the miracles and sinlessness of the Perfect Human in al-Jīlī's thought. Chapter 4 will explore the important concept, closely related to the idea of the Perfect Human, of the 'Pole' of existence. And following that, in Chapter 5 we will consider another important and closely connected Ibn 'Arabian concept, namely, the idea of the 'Muhammadan Reality'. We shall also consider the related question of who this Perfect Human is, or was, from al-Jīlī's and his predecessors' point of view, the subject of Chapter 6. I hope that by structuring the discussion in this way, I will be able to draw out both the key elements of al-Jillī's treatment of the idea and what is distinctive about his treatment.

To anticipate my conclusions, we shall see that al-Jîli goes further than his Ibn 'Arabian predecessors in laying emphasis on the divine aspect of the Perfect 


\section{Introduction}

Human; that he was more explicit than his predecessors in identifying the one true Perfect Human with the Prophet Muhammad; and that, much more than the earlier thinkers in the Ibn 'Arabian tradition, he put the idea of the Perfect Human at the very centre of his Sufi metaphysics. In the conclusion, finally, I shall briefly consider both the possible reasons for these distinctive elements of al-Jîlī's treatment of the idea of the Perfect Human, and the impact that his conception had on later Sufi thought. The present book therefore serves not only as a comprehensive introduction to the Ibn 'Arabian idea of the Perfect Human, but also makes a contribution to our understanding of the historical development of this key idea, from Ibn 'Arabī to al-Jīlī and beyond. In this way, it seeks to make a novel contribution to the study of Ibn 'Arabian Sufism and the history of Islamic thought more generally.

\section{Notes}

1 A. Hourani, A History of the Arab Peoples, intr. M. Ruthven (London: Faber \& Faber, 2013), 177.

2 S. Ahmed, What is Islam? The Importance of Being Islamic (Princeton, NJ: Princeton University Press, 2016), 21. See also ibid., 79.

3 I prefer to use the term Ibn 'Arabian, rather than the more common 'Akbarian', so as to avoid any impression that my analysis comes from within that tradition; that is, that I recognise Ibn 'Arabī as 'The Greatest Master' (al-shaykh al-akbar). As I explain below, my interest in Ibn 'Arabī and al-Jīli is as a historian of ideas.

4 Al-J̄̄ilì, al-Insānn al-kāmil fì ma'rifat al-awākhir wa-al-awā'il, ed. Ș. 'Uwayḍah (Beirut: Dār al-Kutub al-'ilmiyyah, 1997). In the absence of a critical edition of al-Insān al-kāmil, I use the 1997 Beirut edition because it seems to me the easiest both to access and to navigate.

5 R.A. Nicholson, Studies in Islamic Mysticism (Richmond, UK: Curzon Press, 1921), 77-142.

6 De l'homme universel: extraits du livre al-Insân al-kâmil, tr. T. Burckhardt (Paris: Dervy-livres, 1956). This translation was in turn translated into English by Angela Culme-Seymour of the Beshara School (a contemporary 'New Religious Movement' that takes Ibn 'Arabī as its guide) in 1983. For translations of al-Jîlì's more minor works into European languages, see: Das Buch der vierzig Stufen, nach einer Bagdader Handschrift hrsg, tr. E. Bannerth (Vienna: R.M. Rohre, 1956); Die Risāla arba ìn mawātin des 'Abdalkarīm al-Ǧìlì, tr. D. Mann (Doctoral thesis, Saarbrücken, 1970); Göttliche Vollkommenheit und die Stellung des Menschen: die Sichtweise 'Abd al-Karīm al Ğìlīs auf der Grundlage des "Sarh muškilāt al-futūhāat al-makkīya", tr. Angelika Al-Massri (Stuttgart: Deutsche Morganländische Gesellschaft, 1998); Un commentaire esoterique de la formule inaugurale du Coran: Les Mystêres Cryptographiques de "Bismi-Llâhi-r-Rahmâni-r-Rahîm: Al-Kahf wa-r-Raqîm fì Sharh Bismi-Llâhi-r-Rahmâni-r-Rahîm, tr. J. Clément-François (Paris: Editions AlBouraq, 2002); I Nomi divini e il Profeta alla luce del sufismo (Al-Kamālāt al-ilāhiyyah fī al-șifāt al-Muhammadiyyah), tr. C. Marzullo (Turin: Il leone verde, 2015).

7 Al-J̄̄ili, Ibdā' al-kitābah wa-kitābat al- 'ibdā' ('ayn 'alá al-'ayniyyah: sharh mu 'āṣir li-'ayniyyat al-imām al-șūfì 'Abd al-Karìm al-Jīlī [=al-Nādirāt al-'ayniyyah], ed. S. al-Hakīm (Beirut: Dār al-Burāq, 2004), 5.

8 See also the titles of some of his lost works, e.g. al-Mamlakah al-rabbāniyyah fi alnash'ah al-insāniyyah (The Lordly Kingdom in the Human Organism), Insān 'ayn al-wujūd wa-wujūd 'ayn al-insān al-mawjüd (The Human is the Source of Existence and Existence is the Source of the Human Being). See also al-Jîlì's statement in 
al-Kamālāt al- 'ilāhiyyah that the human being is "the goal of existence" (al-maqșūd min al-wujūd), quoted in al-S. Tarjumān, Nazariyyat wahlat al-wujūd bayn Ibn 'Arabī wa-al-Jīlì (Beirut: Manshūrāt Maktabat Khaz'al, 2002), 546.

9 Al-Jīlī, al-Insān, 207.

10 The best treatment of the idea of the Perfect Human as it appears in the writings of Ibn 'Arabī is M. Takeshita, Ibn 'Arabī's Theory of the Perfect Human and Its Place in the History of Islamic Thought (Doctoral thesis, University of Chicago, 1987). Takeshita, however, while focusing on the roots of the idea in earlier Islamic thought, does not discuss the development of the idea in the later Ibn 'Arabian tradition.

11 For a succinct overview of the Qūnawi tradition, see W. Chittick, Encyclopaedia Iranica (online edition), s.v. "EBN AL-'ARABĪ, MOHYYĪ-al-DĪN Abū 'Abd-Allāh Moḥammad Țầ' î̀ātemī.

12 The history of ideas approach that I am following was pioneered by Arthur Lovejoy (d. 1962). See esp. A. Lovejoy, The Great Chain of Being: A Study of the History of an Idea (Cambridge, MA; London: Harvard University Press, 2001).

\section{Bibliography}

Ahmed, Shahab. What is Islam? The Importance of Being Islamic. Princeton, NJ: Princeton University Press, 2016.

Chittick, William C. "EBN AL-'ARABĪ, MOḤYĪ-al-DĪN Abū 'Abd-Allāh Moḥammad Țầ' ì Hătemī”, Encyclopaedia Iranica, online edition.

Hourani, Albert. A History of the Arab Peoples (updated edition). Introduced by Malise Ruthven. London: Faber \& Faber, 2013.

Jīlī, 'Abd al-Karīm. Das Buch der vierzig Stufen, nach einer Bagdader Handschrift hrsg. Translated by Ernst Bannerth. Vienna: R.M. Rohrer, 1956.

Jīlī, 'Abd al-Karīm. De l'homme universel: extraits du livre al-Insân al-kâmil. Translated by Titus Burckhardt. Paris: Dervy-livres, 1956.

Jīlī, 'Abd al-Karīm. Al-Insān al-kāmil fì ma'rifat al-awākhir wa-al-awā'il. Edited by Șalāḥ ibn Muḥammad 'Uwayḍah. Beirut: Dār al-Kutub al-'ilmiyyah, 1997.

Jīlī, 'Abd al-Karīm. Göttliche Vollkommenheit und die Stellung des Menschen: die Sichtweise 'Abd al-Karīm al Ǧ̄ilìs auf der Grundlage des "Šarh muškilāt al-futūhāt al-makkīya". Edited by Angelika Al-Massri. Stuttgart: Deutsche Morganländische Gesellschaft, 1998.

Jīlī, 'Abd al-Karīm. Un commentaire esoterique de la formule inaugurale du Coran: Les Mystêres Cryptographiques de "Bismi-Llâhi-r-Rahmâni-r-Rahîm: Al-Kahf wa-r-Raqîm fỉ Sharh Bismi-Llâhi-r-Rahmâni-r-Rahîm. Translated by Jâbir Clément-François. Paris: Editions AlBouraq, 2002.

Jīlī, 'Abd al-Karīm. Ibdā' al-kitābah wa-kitābat al-'ibdā' ('ayn 'alá al-'ayniyyah: sharh mu 'āṣir li- 'ayniyyat al-imām al-șüfì 'Abd al-Karīm al-Jīlì) [=al-Nādirāt al- 'ayniyyah]. Edited and commented on by Su'ād al-Ḥakīm. Beirut: Dār al-Burāq, 2004.

Jīlī, 'Abd al-Karīm. I Nomi divini e il Profeta alla luce del sufismo (Al-Kamālāt al-ilāhiyyah fī al-șifāt al-muhammadiyyah). Translated by Claudio Marzullo. Turin: Il leone verde, 2015.

Lovejoy, Arthur. The Great Chain of Being: A Study of the History of an Idea. Cambridge, MA; London: Harvard University Press, 2001.

Nicholson, Reynold A. Studies in Islamic Mysticism. Richmond, UK: Curzon Press, 1921.

Takeshita, Masataka. Ibn 'Arabi’s Theory of the Perfect Man and its Place in the History of Islamic Thought. Doctoral thesis, University of Chicago, IL, 1987.

Tarjumān, Suhaylah. Nazariyyat waḥdat al-wujūd bayn Ibn 'Arabī wa-al-Jīlī. Beirut: Manshūrāt Maktabat Khaz'al, 2002. 
ghurabā' al-sharq), ${ }^{114}$ or expressing the nature of the divine essence through the story of "the bird of holiness (tayr al-quds)", ${ }^{115}$ or explaining the reason for religious difference through the story of how Adam's descendants split apart (iftaraqat) after his death. ${ }^{116}$ All of these features, along with his aforementioned use of the Qur'an and hadith, can be seen to a greater or lesser degree in his treatment of the Perfect Human.

\section{Notes}

1 See Nicholson, Studies, 81; A. Knysh, Ibn 'Arabi in the Later Islamic Tradition: The Making of a Polemical Image in Medieval Islam (Albany, NY: State University of New York Press, 1999), 248; R. Atlagh, Contribution à l'étude de la pensée mystique d'Ibn 'Arabì et son école à travers l'oeuvre de 'Abd al-Karīm al-Jīlī (Doctoral thesis, École pratique des hautes études, 2000), 16-17. (My thanks to Claudio Marzullo for helping me to get access to Atlagh's thesis.) Thus, while his master al-Jabartī appears in the biographical dictionaries compiled by Ibn Hajar al-'Asqalānī (d. 1449), al-Sharjī al-Zabīdī (d. 1488), and al-Sakhāwī (d. 1497), these works make no mention of al-Jîlī.

2 See al-Jīlì, Ibdā', 10.

3 See al-J̄̄lì, al-Manāzir al-ilāhiyyah, ed. N. al-Ghunaymī (Cairo: Dār al-Manār, 1987), 12-14; Y. Ziedan, al-Fikr al-șüfì 'ind 'Abd al-Karīm al-Jìlī (Cairo: Dār al-Amīn, 1998), 26-27; al-Hakīm in al-Jîlīi, Ibdā', 10. This is also the date given by I. Goldziher, EI $I^{1}$, s.v., "Abd al-Karīm al-Djīlı̄”; Nicholson, Studies, 81; H. Ritter, $E I^{2}$, s.v. "Abd al-Karīm al-Dj̄̄ll̄”; al-Tarjumān, Nazariyyat, 541-542; C. Brockelmann, Geschichte der Arabischen Litteratur, in two volumes (Leiden: Brill, 1943-1949), 205, however, puts his birth in 777/1375/1376.

4 Goldziher, $E I^{1}$, "Abd al-Karīm al-Djīlı̄”; Ziedan, al-Fikr, 29; al-Tarjumān, Nazariyyat, 541-542. This view seems to be based on a comment made by al-Jīli in Qāb al-qawsayn that he is "Baghdadi in origin" (Baghdādi așlan). See Nicholson, Studies, 81; al-J̄̄lì̄, al-Manāzir, 11; al-J̄̄lì̄, Ibdā', 12. As Marzullo notes, however, așl refers generically to family "origin", and not necessarily to birthplace. See al-Jīlì, I Nomi, 7.

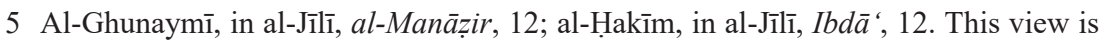
based on a report related by the Yemeni historian al-Khazrajī (d. 1409) in his Tirāa $z$ a'māl al-zamān about a Sufi who lived and died in Abyāt Ḥusayn called Ibrāhīm al-Jīlin, whom al-Ghunaymī takes to be al-Jīlin's father. Al-Jîlī's father, however, seems to have died in Aden. See Atlagh, Contribution, 21.

6 See Atlagh, Contribution, 20-21. Atlagh's view is based on a poem that appears in a colophon of a manuscript of al-Jîlì's Ghunyat arbāb al-sam $\bar{a}^{\prime}$ in the British Library. 'Abd al-Ghanī al-Nābulusī (d. 1731), author of a commentary on al-Nādirāt al'ayniyyah and the last chapter of al-Insān al-kāmil, also believed al-Jîli to have been born in India. See Y. Ziedan, 'Abd al-Karīm al-Jìlī: faylasūf al-șüfiyyah (Cairo: alHay'ah al-Mișriyyah 'āmmah li-l-kitāb, 1988), 15.

7 Nicholson, Studies, 81, following Goldziher, $E I^{1}$, s.v. “"Abd al-Karīm al-Djīlı̄”.

8 Al-Ghunaymī, in al-J̄̄lì, al-Manāżir, 18.

9 Ritter, $E I^{2}$, s.v. “"Abd al-Karīm al-Djīlī”. Ritter's source seems to be Brockelmann, Geshichte, 2:205-206.

10 Knysh, Ibn 'Arabi, 429. 
11 Ziedan, al-Fikr, 26; al-Ḥakīm, in al-Jīlī, Ibdā', 17; al-Tarjumān, Nazariyyat, 573-575. This view is based on a comment of the anti-Ibn 'Arabi Yemeni historian Abd al-Raḥmān Ibn al-Ahdal (d. 1481).

12 V. Hoffman, "Annihilation in the Messenger of God: The Development of a Sufi Practice", International Journal of Middle East Studies 31, no. 3 (1999), 351-369; Atlagh, Contribution, 20-21.

13 Journeys between Calicut and Aden, primarily for the purposes of trade, were common in this period, as noted for instance by Ibn Bațūțah. See Ibn Bațtūtah, The Travels of Ibn Battuta, A.D. 1325-1354, in five volumes, tr. H.A.R. Gibb (Cambridge: Haklyut Society from the University Press, 1958-2000), 2:372.

14 Atlagh, Contribution, 20-21.

15 See Atlagh, Contribution, 21-24; al-Jīlī, Ibdā', 13-16; Ziedan, 'Abd al-Karìm, 15-21; Ziedan, al-Fikr, 29-30; al-Jīlì, al-Insān, 189. These are merely the places (apart from Zabid) and dates that al-Jīli mentions in his writings, and we should not rule out the possibility that he travelled elsewhere or spent longer in the places that he mentions.

16 See M. Dols, The Black Death in the Middle East (Princeton, NJ: Princeton University Press, 1977), 212. For the destructive effect of the Black Death on the region, see Ibn Khaldūn, The Muqaddimah: An Introduction to History, in three volumes, tr. F. Rosenthal (London: Routledge \& Kegan Paul, 1958) [hereafter "Ibn Khaldūn, The Muqaddimah"], 1:64.

17 G. Lane, Early Mongol Rule in Thirteenth Century Iran: A Persian Renaissance (London: Routledge Curzon, 2003), 9.

18 See R.E. Dunn, The Adventures of Ibn Battuta (London; Sydney: Croom Helm, 1986), 192.

19 See M. Hodgson, The Venture of Islam: Conscience and History in a World Civilization, in three volumes (Chicago, IL; London: University of Chicago Press, 1974), 2:371.

20 See ibid., 2:201-254.

21 See J.S. Trimingham, The Sufi Orders in Islam (Oxford: Clarendon Press, 1971), 233-241.

22 See M. Chodkiewicz, An Ocean Without a Shore: Ibn 'Arabî, the Book, and the Law, tr. D. Streight (Albany, NY: State University of New York Press), 1-18.

23 See Knysh, Ibn 'Arabi; A. Akasoy, "What is Philosophical Sufism?" In the Age of Averroes: Arabic Philosophy in the Sixth/Twelfth Century, ed. P. Adamson (London; Turin: Warburg Institute, 2011), 229-249.

24 See Hodgson, Venture, 2:250-252; J. Brown, Misquoting Muhammad: The Challenge and Choices of Interpreting the Prophet's Legacy (London: Oneworld Academic, 2015), 227-228.

25 See M. Katz, The Birth of the Prophet Muhammad: Devotional Piety in Sunni Islam (London: Routledge, 2007). See also M. Chodkiewicz, Seal of Saints: Prophethood and Sainthood in the Doctrine of Ibn 'Arabī, tr. L. Sherrard (Cambridge: Islamic Texts Society, 1999), 67: "During the age of Ibn 'Arabī, on the initiative of the Ayyubids or, rather, of the Șūfis who inspired them, the Prophet's mawlid, or birthday, began to be celebrated on a regular basis."

26 See A. Schimmel, And Muhammad is His Messenger: Veneration of the Prophet in Islamic Piety (Chapel Hill, NC; London: University of North Carolina Press, 1985), 177-215.

27 See B. Shoshan, Popular Culture in Medieval Cairo (Cambridge: Cambridge University Press, 1993), 23-39. 
28 For al-Jazūlī and his Dalā'il al-khayrāt, see V. Cornell, Realm of the Saint: Power and Authority in Moroccan Sufism (Austin, TX: University of Texas Press, 1998), 155-195, 211-213.

29 See J. Katz, Dreams, Sufism, and Sainthood: The Visionary Career of Muhammad al-Zawâwî (Leiden: Brill, 1996).

30 On this idea, see U. Rubin, "Pre-Existence and Light: Aspects of the Concept of Nur Muhammad". Israel Oriental Studies 5 (1975), 62-119; Rubin, E${ }^{2}$, s.v. "Nūr Muhammadī."

31 See Rubin, $E I^{2}$, s.v. "Nūr Muhammadī”; Knysh, Ibn 'Arabi, 192-193.

32 From a different perspective, the exaltation of the Prophet can also be seen in the emergence for the first time in the fourteenth century of treatises on blasphemy against the Prophet Muhammad, such as Ibn Taymiyyah's (d. 1328) al-Șārim al-maslūl 'alá shātim al-rasūl (The Sword Unsheathed Against Whoever Insults the Messenger) and Tāqī al-Dīn al-Subkī's (d. 1355), al-Sayf al-mastūl 'alá man sabba al-rasūl (The Sword Unsheathed Against Whoever Blasphemes Against the Messenger). See C. Sahner, Christian Martyrs under Islam: Religious Violence and the Making of the Muslim World (Princeton, NJ: Princeton University Press, 2018), 124-125.

33 Thus, for instance, Dāwūd al-Qayșarī's widely read Muqaddimah (introduction) to his commentary on the Fușus begins with a treatment not of God or the divine essence but of "existence" (al-wujūd) as such.

34 See J. Morris, "Ibn 'Arabī and His Interpreters", Journal of the American Oriental Society (Michigan) 106, no. 3 (1986), 539-564, 106, no. 4 (1986), 733-756, 107, no. 1 (1987), 101-120; Akasoy, "What is Philosophical Sufism?", 242-249; R. Todd, The Sufi Doctrine of Man: Șadr al-Dīn al-Qūnawī's Metaphysical Anthropology (Leiden: Brill, 2014); A. Shaker, Thinking in the Language of Reality: Sadr al-Dīn Qūnavī (1207-74 CE) and the Mystical Philosophy of Reason (USA: XLibris, 2015); C. Dagli, Ibn al-'Arabī and Islamic Intellectual Culture: From Mysticism to Philosophy (London: Routledge, 2016). On the storytelling of the Fușuss, see R. Nettler, Sufi Metaphysics and Qur'ānic Prophets: Ibn 'Arabī's Thought and Method in the Fuṣūṣ al-hikam (Cambridge: Islamic Texts Society, 2003), 13-16. Ibn 'Arabī's discussion of the letters of the alphabet comes in chapter 2 of the Futūhat, and his discussion of the pillars of Islam in chapters 67-72. It is notable that al-Jīi does in fact take forward these other aspects of Ibn 'Arabī's thought, in addition to him being influenced by the more metaphysically minded Sufi thought of al-Qūnawī and his followers.

35 Ahmed, What is Islam?, 31. It is significant that Ahmed explicitly identifies al-Jīli as being part of this Sufi-philosophical amalgam. See ibid., 94-95.

36 See Hodgson, Venture, 2:323-325.

37 See A. Dhanani, "Al-Mawāqif fì 'ilm al-kalām by 'Aḍ̂̄d al-Dīn al-İjī (d. 1355), and Its Commentaries", The Oxford Handbook of Islamic Philosophy, ed. K. El-Rouayheb and S. Schmidtke (New York: Oxford University Press, 2016), pp. 375-396; M. Mahdi, Ibn Khaldūn's Philosophy of History: A Study in the Philosophic Foundation of the Science of Culture (London: G. Allen \& Unwin, 1957), 31-33. Ibn Khaldūn's statement can be found in Ibn Khaldūn, The Muqaddimah, 3:52; Ibn Khaldūn, Muqaddimah, in three volumes, ed. 'A. Wāfī (Cairo: Dār Nahdat Miṣr li-al-nashr, 2014) [hereafter "Ibn Khaldūn, Muqaddimah"], 976-977.

38 See É. Vallet, L'Arabie marchande: État et commerce sous les sultans Rasulides du Yémen (626-858/1229-1454) (Paris: Publications de la Sorbonne, 2010). For the development of Aden as a trading hub in the centuries prior to the arrival of the Rasulids, see R.E. Margariti, Aden \& the Indian Ocean Trade: 150 Years in the Life 
of a Medieval Arabian Port (Chapel Hill, NC: University of North Carolina Press, 2007).

39 According to the Encyclopaedia of Yemen, there were approximately 240 mosques and madrasas in Zabid in the first half of the fourteenth century. See A.J. 'Afiff, al-Mawsū'ah al-yamaniyyah, in four volumes (Sanaa: Mu'assassat al-'Afíf al-thaqāfiyyah, 2003), 2:1445.

40 G.R. Smith, $E I^{2}$, s.v. "Tihāma".

41 For the Rasulids, see G.R. Smith, EI ${ }^{2}$, s.v. "Rasulids"; J. Chelhod (ed.), L'Arabie du sud: histoire et civilisation, in three volumes (Paris: Maisonneuve et Larose, 1984), 2:40-47.

42 In this regard, al-Sharjī al-Zabīdī tells us in his biographical dictionary of Yemeni Sufis, Tabaqāt al-khawāșs, that al-Jabartī "was without rival among the shaykhs of

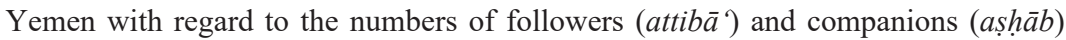
that he had from among the kings (al-mulük), governors (al-wulāh) and scholars (al-'ulamā')'". Al-Zabīdī, Țabaqāt al-khawāșș, ahl al-șidq wa-al-ikhlāṣ (Sana'a; Beirut: al-Dār al-Yamaniyyah li-al-nashr wa-al-tawzī‘, 1986), 101.

43 Quoted in Vallet, L'Arabie marchande, 388.

44 For Sufism in Rasulid Yemen, see A. al-Hibshī, al-Süfiyyah wa-al-fuqahā' fì alYaman (Sanaa: Tawzī' maktabat al-jīl al-jadīd, 1976), passim, esp. 95-167; Knysh, Ibn 'Arabi, 225-269.

45 In a similar vein, al-Qūnawī and his students were enabled to develop the ideas of Ibn 'Arabī by "the generally favourable attitude of the Seljuq sultans [of Rūm] towards Sufism”. Todd, Sufi Doctrine, 6.

46 See Knysh, Ibn 'Arabi, 242, 376, note 106; M. Chodkiewicz, "Le process posthume d'Ibn 'Arabì', Islamic Mysticism Contested, ed. F. de Jong and B. Radtke (Leiden: Brill, 1999), 93-123, 114-123.

47 Knysh, Ibn 'Arabi, 252-254; al-Hibshī, al-Ṣüfyyah, 99.

48 Knysh, Ibn 'Arabi, 256-257. See also al-Hibshī, al-Ṣüiyyah, 100.

49 See e.g. Knysh, Ibn 'Arabi, 237, 243, 248, 249, 251, 259; al-Jīlī, al-Manāzir, 33.

50 Ibn al-Ahdal, Kashf al-ghițā' 'an haqā'iq al-tawhīd wa- 'aqā'id al-muwahhidīn wadhikr al-a'immah al-ash 'ariyyīn wa-man khālafahum min al-mubtadi 'ìn wa-bayān hạal Ibn 'Arabī wa-attibā'ihi al-māriqin (Removing the Veil from the Truths of Monotheism and the Doctrines of the Monotheists, and Remembering the Imams of the Ash 'arites and Those Innovators who Opposed Them, and Clarifying the Condition of Ibn 'Arabī and His Renegade Followers) (Tunis: Aḥmad Bakīr Mạ̣mūd, 1964), 214. Similarly, he accuses Ibn 'Arabī himself of "not keeping to the limits of the Muhammadan Law (lam yataqayyid bi-qayd al-sharī'ah al-Muhammadiyyah)”. Ibid., 182.

51 Al-J̄̄lì, al-Insān, 5, 52, 149, 215, 203, 229, 255.

52 See ibid., 211.

53 Ibn al-Ahdal, Kashf, 214.

54 The term "Sufi metaphysics" is applied by Ron Nettler to the thought of Ibn "Arabī. See Nettler, Sufi Metaphysics, 3-5. It is also used by Muhammad Iqbal, including with respect to al-Jīlī, for which see M. Iqbal, The Development of Metaphysics in Persia: A Contribution to the History of Muslim Philosophy (London: Luzac \& Co., 1908), 112ff. Ziedan calls al-Jīli "the philosopher of the Sufis" (faylasüf al-șüfiyyah) and "the Sufi philosopher" (al-șüfi faylasūf) (see Ziedan, 'Abd al-Karīm, esp. 5-7), terms, I think, which might lead to an exaggerated view of the influence of falsafah upon al-Jīili.

55 Al-Jīli also tells us that he was initiated into the Chishtiyyah while on pilgrimage in Mecca in 799 AH [=1397]. See Atlagh, Contribution, 23. 
56 See e.g. Al-Jīlī, al-Insān, 210.

57 See ibid., 204-205; al-Jīî̀, al-Manāẓir, 168-169.

58 Owing to the similarity in their names, some, notably Hājjjī Khalīfah [=Kātib Čelebī] (d. 1657), have thought al-Jilin to be a lineal descendant of 'Abd al-Qādir. While Ziedan and al-Hakīm reject this (see Ziedan, al-Fikr, 38; al-Hakīm in al-Jîlì, Ibdā', 11), Atlagh has found a manuscript of al-Kahf wa-al-raqīm in which al-Jīili is referred to as " $\mathrm{Abd}$ al-Karīm b. sibṭ al-shaykh 'Abd al-Qādir al-Jīlān $\vec{\imath}$ ”. Nevertheless, Atlagh also notes that al-Jīli usually refers to "Abd al-Qādir as "our shaykh", without mentioning that he is related by blood. See Altagh, Contribution, 10, 20-21; Marzullo in al-Jīlì, I Nomi, 8.

59 See al-Jīlī, al-Manāzir, 31 .

60 It should be noted that there is considerable debate in modern philosophy and religious studies on the definition of "mystical experience" and the defining features of such experiences. For an overview of those debates, see J. Gellman, The Stanford Encyclopaedia of Philosophy, s.v. "Mysticism".

61 See e.g. al-Jīìi, al-Insān, 11, 39, 65, 68, 69, 71-72, 79-80, 100, 125, 193, 210. Ibn 'Arabī uses the same terms to denote his own experiences. See S. al-Hakīm, alMu 'jam al-șüfĩ: al-hikmah fì hudūd al-kalimah (Dandarah li-al-ṭabā'ah wa-al-nashr, 1981), 492-495, 662-665, 863-870.

62 Al-Jīili, al-Insān, 79-80.

63 Ibid., 65. Compare Ibn 'Arabī's claims that both the Futūhāt and Fuṣūṣ were products of divine inspiration or revelation ( $f a t h$, ilhām, ilqā', tanzīl), quoted in Nettler, Sufi Metaphysics, 5-6; Chodkiewicz, Seal, 225; N.H. Abū Zayd, Hākadhā takallama Ibn 'Arabī (Casablanca; Beirut: Dār al-Thaqāfĩ al-'Arab̄̄, 2006), 99-102. Similar claims are also made by al-Qūnawī and al-Qayșarī. See Todd, Sufi Doctrine, 32-33; A, Zildžić, Friend and Foe: The Early Ottoman Reception of Ibn 'Arabī (Doctoral thesis, University of California, Berkeley, 2012), 62.

64 See al-Jîlī, al-Insān, 11: "God opened up (fataha) knowledge of the Book and Sunnah to me." Ibid., 125: “And I have brought together (jama 'atuh) in these pages all that the Torah contains, according to what God unveiled to us about that ('alá hasb mā kashafa lanā Allāh 'an dhālik)."

65 See ibid., 121. This connection between the knowledge obtained via mystical experience and the knowledge obtained via prophecy underlies the close connection between walāyah and nubuwwah, on which see Chapter 2 below.

66 Al-Jîlī, al-Insān, 232. As many scholars have pointed out, the Prophet's mi 'rāj functioned as a paradigm for Sufi conceptions of their own mystical experiences. See M. Sells (ed. and tr.) Early Islamic Mysticism: Sufi, Qur'an, Mi'raj, Poetic and Theological Writings (New York: Paulist Press, 1996), 47, and the references in S. Taji-Farouki, Beshara and Ibn 'Arabi: A Movement of Sufi Spirituality in the Modern World (Oxford: Anqa, 2007), 340, note 49. Thus Ibn 'Arabī also claims to have undergone his own mi 'rāj. See J. Morris, "The Spiritual Ascension: Ibn 'Arabi and the Mi'raj”, Journal of the American Oriental Society (Michigan) 107, no. 4 (1987), 629-652, 108, no. 1 (1988), 63-77.

67 See M. Ebstein, Mysticism and Philosophy in al-Andalus: Ibn Masarra, Ibn al- 'Arabī and the Ismaili Tradition (Leiden: Brill, 2014), 21-27, who identifies five different mystical types within medieval Islamic thought.

68 For Sufi approaches to the Qur'an, see A. Knysh, Encyclopaedia of the Qur'ān, s.v. "Sufism and the Qur'ān"; K.Z. Sands, Șüfì Commentaries on the Qur'ān In Classical Islam (London: Routledge, 2006).

69 Al-Jîlī, al-Insān, 11. See also ibid., 79-80: 
So understand what I have indicated to you in these expressions - indeed, in the whole of this book of mine, since most of the issues of this book have no precedent, except for what has been [referred to] in technical language, for there is no way to talk about a form of knowledge except in the technical language of its practitioners.

Hājjjī Khalīfah describes al-Insān al-kāmil as "a book on the technical language of the Sufis (iștiliāh al-șüfiyyah)". Ḥājjī Khalīfah, Kashf al-ẓunūn 'an asāmi al-kutub wa-al-funūn, in seven volumes, ed. G. Flugel (Leipzig: Oriental Translation Fund for Great Britain and Ireland, 1835-1858), 1:459.

70 See al-Jîlī, al-Insān, 11, 79-80.

71 See e.g. ibid., 65-67.

72 See e.g. ibid., 65.

73 See e.g. ibid., 267.

74 See e.g. ibid., 39, 67, 68, 205, 266.

75 In this regard, it should be noted that, alongside the works of Ibn 'Arabī and his interpreters, al-Jabartī also taught the classical Sufi manuals, such as the Risālah of al-Qushayrī (d. 1072) and 'Awārif al-ma 'ārif of Abū Hafs 'Umar al-Suhrawardī (d. 1234). See Knysh, Ibn 'Arabi, 242-243. Notice should also be made of the fact that the Ibn 'Arabian Sufis wrote commentaries on certain classical manuals: for instance, al-Qāshānī's commentary on 'Abd Allāh Anșārī's Manāzil al-sā'irīn.

76 See P. van Inwagen and M. Sullivan, The Stanford Encyclopaedia of Philosophy, s.v. "Metaphysics". Thus Ibn Sīnā defines metaphysics or "the divine science" (al- 'ilm al-ilahhi) as the investigation of "the existent qua existent" (al-mawjūd bi-mā huwa mawjūd). Quoted in Dhanani, "Al-Mawāqif", 376. See also A.M. Goichon, Lexique de la langue philosophique d'Ibn Sinnà (Avicenne) (Paris: Desclée de Brouwer, 1938), 282: "The first philosophy (al-falsafah al-ūlá), the subject of which is the absolute existent (al-mawjüd al-muțlaq) qua absolute existent."

77 See Chapter 2 below.

78 See e.g. Al-Jīlī, al-Insān, 81, 86, 89, 128. According to H. Corbin, History of Islamic Philosophy, tr. L. Sherrard and P. Sherrard (London: Kegan Paul, 1993), 30, the title imām "in many cases means the head of a school".

79 See e.g. al-J̄̄ilī, Sharh mushkilāt al-Futūḥāt al-Makkiyyah, ed. Y. Ziedan (Cairo: Dār al-Amīn, 1999), 126, 127. The title 'al-Shaykh al-akbar' (The Greatest Shaykh), which is often mentioned in modern studies on Ibn 'Arabī, only seems to have come into use in the Ottoman period. See S. Hirtenstein, "Names and Titles of Ibn [al-]'Arabì”, Journal of the Muhyidding Ibn 'Arabi Society 41 (2007), 109-129, $124-128$.

80 Al-Jīlì is credited with commentaries on (chapter 559 of) al-Futūḥāt al-Makkiyyah, Risālat al-Anwār, and Kitāb al-Tajalliyyāt, though Chodkiewicz has called into question the authorship of the last commentary. See M. Chodkiewicz, "The Vision of God according to Ibn 'Arabi", Prayer and Contemplation, a special issue of the Journal of the Muhyiddin Ibn 'Arabi Society 14 (1993), 53-67, 60.

81 See al-Jīlì, Ibdā', 13-14.

82 We do not know al-Jīlī's madhhab for sure. According to I. al-Baghdādī, Hidāyat al- 'ārifìn: asmā' al-mu'allifin wa-āthār al-mușannafin, in two volumes (Istanbul: Wikālat al-Ma‘ārif, 1951-1955), 610, he was a Ḥanbalī. However, if as Atlagh suggests, al-Jīlī was originally from Calicut, we might suppose he was a Shāfi‘ ${ }^{\prime}$, Shāfi'ism being the dominant madhhab in the Malabar coastal region (as it was in southern Yemen, which al-Jīlī made his home). 
83 See al-Jīlī, al-Insān, 6-7.

84 Ibid., 11. See also the lines of verse to this same effect in ibid., 177.

85 See e.g. al-Sarrāj, Kitāb al-Luma 'fì al-tașawwuf, ed. R.A. Nicholson (Leiden: Brill, 1914), 5; 'A.H. 'Abdel-Kader, The Life, Personality and Writings of Al-Junayd (Selangor, Malaysia: Islamic Book Trust, 2013), 3; A. Karamustafa, Sufism: The Formative Period (Berkeley, CA: University of California Press, 2007), 40, 71, 89, 103; Abū Zayd, Hākadhā, 251.

86 See Nettler, Sufi Metaphysics, 12-13. The writings of al-Qūnawī (and his followers) are probably less Qur'an centred than both those of Ibn 'Arabī and al-Jīlī. See Todd, Sufi Doctrine, 50-51.

87 See al-Jīlī, al-Insān, 210.

88 See al-J̄ilì, $I b d \bar{a}^{\prime}, 25$.

89 See Atlagh, Contribution, 20.

90 For this work, see R. Atlagh, "LE POINT ET LA LIGNE: Explication de la Basmala par la science des lettres chez 'Abd al-Karīm al-Ğîlī (m. 826 h.)", Bulletin d'études orientales 44, SCIENCES OCCULTES ET ISLAM (1992), 161-190; N. Lo Polito, 'Abd al-Karìm al-Jīlì: Tawhīd, Transcendence, and Immanence (Doctoral thesis, University of Birmingham 2010), 138-270.

91 See al-Jîlīi, Ibdā', 24.

92 On which, see al-Jīlì, Ibdā', 25, 37-43; Atlagh, Contribution, 99-103. A critical edition of the Ghunyah is being prepared by Claudio Marzullo for a doctorate at the University of Naples.

93 Al-Jīin̄, Al-Kamālāt al-ilāhiyyah fì al-ṣifāt al-Muhammadiyyah, ed. and tr. S. 'Abd al-Fattāḥ (Cairo: 'Ālam al-fikr, 1997); Al-Jīlī, I Nomi. See also Atlagh, Contribution, 93-98.

94 See Y. Nabhānī, Jawāhir al-biḥār fì fad̄à'il al-nabī al-mukhtār, in four volumes, ed. M. al-Ḍannāwī (Beirut: Dār al-Kutub al-'ilmiyyah, 1998), 1:1494-1520; C. Addas, “"At the Distance of Two Bows' Length or even Closer': The Figure of the Prophet in the Work of 'Abd al-Karīm al-Jîlì”, Journal of the Muhyiddin Ibn 'Arabi Society 45 (2009), 65-88, 46 (2009), 1-26. Atlagh, Contribution, 104-110. This is the tenth part of al-Jîlì's huge work in 40 parts, al-Nāmūs al-a 'z̧am wa-al-qāmūs al-aqdam fì ma 'rifat qadr al-nabī, the majority of which is lost.

95 For this work, see al-Jīlī, Göttliche Vollkommenheit; Atlagh, Contribution, 152-161; F. Morrissey, "An Introduction to 'Abd al-Karīm al-Jīlī's Commentary on the Futūhāat”, Maghreb Review 41, no. 4 (2016), pp. 499-526.

96 Al-J̄ilī, Marātib al-wujūd wa-ḥaqīqat kull mawjūd (Cairo: Maktabat al-Qāhirah, 1999). See also Atlagh, Contribution, 142-151.

97 For the most complete list of al-Jîlī's works, see Atlagh, Contribution, 26-27.

98 See Morris, "Ibn 'Arabî̀”, 3:108; Atlagh, Contribution, 16, 78-83; al-J̄illī, Ibdā', 24-28.

99 See Ziedan, 'Abd al-Karīm, 66; al-Jīlì, Ibdā', 23-24.

100 See M. Woodward, Java, Indonesia, and Islam (New York: Springer, 2010), 174. For the influence of al-Jīli on Southeast Asian Sufi thought, a topic which still needs further elucidation, see A.H. Johns, "Malay Sufism: As Illustrated in an Anonymous Collection of 17th Century Tracts", Journal of the Malayan Branch of the Royal Asiatic Society 30, no. 2 (1957), 3-99, 101-111; P. Riddell, Islam and the MalayIndonesian World (Honolulu: University of Hawai'i Press, 2001), 75, 105, 113, 115, $123,137,223,319$.

101 See al-Jīlì, Ibdā', 24. 
102 See Lo Polito, 'Abd al-Karim, 42.

103 See M. Burhānpūrī, The Gift Addressed to the Spirit of the Prophet, ed. and tr. A.H. Johns (Canberra: Australian National University, 1965), 53.

104 See e.g. al-Tahānawī, Kashshāf iștiliāhāt al-funūn, ed. L. 'Abd al-Badī', 'A. Huusayn, and A. Khūlī (Cairo: al-Mu'assasah al-Mișrīyah al- 'āmmah li-lta'līf wa-al-tarjamah wa-al-țibā' ah wa-al-nashr, 1963), 270-271, 816, 1270, 1311-1312, 1746.

105 For this controversy, see S. Akkach, 'Abd al-Ghani al-Nabulusi: Islam and the Enlightenment (Oxford: Oneworld Publications, 2007), 107-108. For al-Qushashī, see A.H. Johns, $E I^{2}$, s.v. "Al-Kushashī". For al-Nābulusī, see Akkach, 'Abd alGhani; E. Sirriyeh, Sufi Visionary of Ottoman Damascus: 'Abd al-Ghan̄̄ al-Nābulusī, 1641-1731 (London: Routledge, 2005).

106 See I. Weismann, "God and the Perfect Human in the Experience of "Abd al-Qadir al-Jaza'iri”, Journal of the Muhyiddin Ibn 'Arabi Society 30 (2001), 55-72, 67-68. For 'Abd al-Qādir, see J. McDougall, $E I^{3}$, s.v. "“Abd al-Qādir, Amīr”; T. WoernerPowell, Another Road to Damascus: An Integrative Approach to 'Abd al-Qādir al-Jazā'irī (1808-1883) (Berlin: De Gruyter, 2017).

107 Trimingham, Sufi Orders, 161.

108 See al-Jazā'irī, al-Mawāqif al-rūhiyyyah wa-al-fuyūḍ̄t al-subūhiyyah, in two volumes, ed. 'A. al-Kayyālī (Beirut: Dār al-kutub al-'ilmiyyah, 2004), 2:289; Weismann, "God and the Perfect Human", 66-68. For the profusion of claims to walayah in late medieval and early modern Sufism, see also Trimingham, Sufi Orders, $162-165$.

109 See A. Moin, The Millennial Sovereign: Sacred Kingship and Sainthood in Islam (New York: Columbia University Press, 2012); İ. Binbaş, Intellectual Networks in Timurid Iran: Sharaf al-Dīn 'Al̄ Yazd̄̄ and the Islamicate Republic of Letters (Cambridge: Cambridge University Press, 2016), esp. 253-258, 273-274; H. Yilmaz, Caliphate Redefined: The Mystical Turn in Ottoman Political Thought (Princeton, NJ: Princeton University Press, 2018), esp. 200-217; C. Markiewicz, Crisis of Kingship in Late Medieval Islam: Persian Emigrés and the Making of Ottoman Sovereignty (Cambridge: Cambridge University Press, 2019), esp. 240-284; Ahmed, What is Islam?, 474-475. It should be noted that the notions of the Pole and the Viceregent of God had had political connotations from their first appearance in post-Qur'anic Islamic literature. See P. Crone and M. Hinds, God's Caliph: Religious Authority in the First Centuries of Islam (Cambridge: Cambridge University Press, 2003), esp. 24-42; N. Jamil, "Caliph and Qutb. Poetry as a Source for Interpreting the Transformation of the Byzantine Cross on Steps on Umayyad Coinage", Bayt alMaqdis, Jerusalem and Early Islam. Oxford Studies in Islamic Art 9, part two, ed. J. Johns (Oxford: Oxford University Press, 1999), 11-57. The late medieval and early modern political conceptions of these ideas, however, were mediated through Sufi conceptions such as those found in Ibn 'Arabian literature.

110 Atlagh, however, does not believe this twofold division to be original to the text. See Atlagh Contribution, 65.

111 Claudio Marzullo divides the two large sections into four subsections: (1) the key concepts of Sufi metaphysics; (2) the manifestation of the divine word (in the scriptures); (3) cosmology; and (4) the Perfect Human, astronomical symbolism, and other religions. See al-Jîlī, I Nomi, 16-17.

112 Thus, for instance, al-Jīl understands the revelation of the scriptures (the Qur'an, Torah, Psalms, and Gospel) as expressions of the manifestation of different levels of God's existence. See esp. al-Jīlī, al-Insān, 127. 
113 See Todd, Sufi Doctrine, 49.

114 See al-Jīlì, al-Insān, $13 \mathrm{ff}$.

115 See ibid., 26ff.

116 See ibid., 254.

\section{Bibliography}

'Abdel-Kader, 'Ali H. The Life, Personality and Writings of Al-Junayd. Selangor, Malaysia: Islamic Book Trust, 2013.

Abū Zayd, Nașr H. Hākadhā takallama Ibn 'Arabì. Casablanca; Beirut: Dār al-Thaqāfī al-'Arabī, 2006.

Addas, Claude. “' At the Distance of Two Bows' Length or even Closer': The Figure of the Prophet in the Work of 'Abd al-Karīm al-Jīlì', Journal of the Muhyiddin Ibn 'Arabi Society 45 (2009), pp. 65-88, 46 (2009), pp. 1-26.

'Afîf, Ahmad J. Al-Mawsū'ah al-yamaniyyah, in four volumes. Sanaa: Mu'assassat al-'Afĩf al-thaqāfiyyah, 2003.

Akasoy, Anna. "What is Philosophical Sufism?" In the Age of Averroes: Arabic Philosophy in the Sixth/Twelfth Century. Edited by Peter Adamson. London; Turin: Warburg Institute, 2011, pp. 229-249.

Akkach, Samir. 'Abd al-Ghani al-Nabulusi: Islam and the Enlightenment. Oxford: Oneworld Publications, 2007.

Atlagh, Riyadh. "LE POINT ET LA LIGNE: Explication de la Basmala par la science des lettres chez 'Abd al-Karīm al-Ğ̄ilī (m. 826 h.)", Bulletin d'études orientales 44, SCIENCES OCCULTES ET ISLAM (1992), pp. 161-190.

Atlagh, Riyadh. Contribution à l'étude de la pensée mystique d'Ibn 'Arabī et son école à travers l'oeuvre de 'Abd al-Karīm al-Jīlì. Doctoral thesis, École pratique des hautes études, 2000.

Baghdādī, Ismā'īl. Hidāyat al- 'ārifîn: asmā' al-mu'allifìn wa-āthār al-mușannafìn, in two volumes. Istanbul: Wikālat al-Ma‘ārif, 1951-1955.

Binbaş, İlker E. Intellectual Networks in Timurid Iran: Sharaf al-Dīn 'Alī Yazdī and the Islamicate Republic of Letters. Cambridge: Cambridge University Press, 2016.

Brockelmann, Carl. Geschichte der Arabischen Litteratur, in two volumes. Leiden: Brill, 1943-1949.

Brown, Jonathan A.C. Misquoting Muhammad: The Challenge and Choices of Interpreting the Prophet's Legacy. London: Oneworld Academic, 2015.

Burhānpūrī, Muhammad. The Gift Addressed to the Spirit of the Prophet. Edited and translated by Anthony H. Johns. Canberra: Australian National University, 1965.

Chelhod, Joseph (ed.). L'Arabie du sud: histoire et civilisation, in three volumes. Paris: Maisonneuve et Larose, 1984.

Chodkiewicz, Michel. An Ocean Without a Shore: Ibn 'Arabî, the Book, and the Law. Translated by David Streight. Albany, NY: State University of New York Press, 1993.

Chodkiewicz, Michel. "The Vision of God according to Ibn 'Arabi", Prayer and Contemplation, a special issue of the Journal of the Muhyiddin Ibn 'Arabi Society 14 (1993), pp. 53-67.

Chodkiewicz, Michel. Seal of Saints: Prophethood and Sainthood in the Doctrine of Ibn 'Arabī. Translated by Liadain Sherrard. Cambridge: Islamic Texts Society, 1999.

Chodkiewicz, Michel. "Le process posthume d'Ibn 'Arabī”, Islamic Mysticism Contested. Edited by Frederick de Jong and Bernd Radtke. Leiden: Brill, 1999, pp. 93-123. 
Corbin, Henry. History of Islamic Philosophy. Translated by Liadain Sherrard and Philip Sherrard. London: Kegan Paul, 1993.

Cornell, Vincent. Realm of the Saint: Power and Authority in Moroccan Sufism. Austin, TX: University of Texas Press, 1998.

Crone, Patricia and Martin Hinds. God's Caliph: Religious Authority in the First Centuries of Islam. Cambridge: Cambridge University Press, 2003.

Dagli, Caner. Ibn al-'Arabì and Islamic Intellectual Culture: From Mysticism to Philosophy. London: Routledge, 2016.

Dhanani, Alnoor. "Al-Mawāqif fì 'ilm al-kalām by "Aḍūd al-Dīn al-Ījī (d. 1355), and Its Commentaries", The Oxford Handbook of Islamic Philosophy. Edited by Khaled El-Rouayheb and Sabine Schmidtke. New York: Oxford University Press, 2016, pp. 375-396.

Dols, Michael W. The Black Death in the Middle East. Princeton, NJ: Princeton University Press, 1977.

Dunn, Ross E. The Adventures of Ibn Battuta. London; Sydney: Croom Helm, 1986.

Ebstein, Michael. Mysticism and Philosophy in al-Andalus: Ibn Masarra, Ibn al- 'Arabī and the Ismà 'îli Tradition. Leiden: Brill, 2014.

Gellman, Jerome. "Mysticism", The Stanford Encyclopaedia of Philosophy, online edition.

Goichon, Amélie M. Lexique de la langue philosophique d'Ibn Sīnā (Avicenne). Paris: Desclée de Brouwer, 1938.

Goldziher, Ignaz. " “Abd al-Karīm al-Djīlī”, Encyclopaedia of Islam, first edition.

Ḥājjī Khalīfah. Kashf al-ẓunūn 'an asāmi al-kutub wa-al-funūn (Lexicon bibliographicum et encyclopcedicum a Mustafa Ben Abdallah Katib Jelebi dicto et nomine Haji Khalfa celebrato compositum: ad codicum vindobonensium, parisiensium et berolinensis, fidem primum), in seven volumes. Edited by Gustav Flugel. Leipzig: Oriental Translation Fund for Great Britain and Ireland, 1835-1858.

Hakīm, Su'ād. Al-Mu ‘jam al-șüfi: al-hikmah fì ḥudūd al-kalimah. Beirut: Dandarah li-alțabā'ah wa-al-nashr, 1981.

Ḥibshī, 'Abd Allāh M. Al-Ṣüfiyyah wa-al-fuqahā' fì al-Yaman. Sanaa: Tawzī‘ maktabat al-jīl al-jadīi, 1976.

Hirtenstein, Stephen. "Names and Titles of Ibn [al-]"Arabī”, Journal of the Muhyidding Ibn 'Arabi Society 41 (2007), pp. 109-129.

Hodgson, Marshall. The Venture of Islam: Conscience and History in a World Civilization, in three volumes. Chicago, IL; London: University of Chicago Press, 1974.

Hoffman, Valerie. "Annihilation in the Messenger of God: The Development of a Sufi Practice", International Journal of Middle East Studies 31, no. 3 (1999), pp. 351-369.

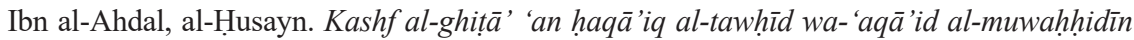
wa-dhikr al-a'immah al-ash 'ariyyīn wa-man khālafahum min al-mubtadi'in wa-bayān hậl Ibn 'Arabī wa-attibā 'ihi al-māriqīn. Tunis: Aḥmad Bakīr Maḥmūd, 1964.

Ibn Batțuttah. The Travels of Ibn Battuta, A.D. 1325-1354, in five volumes. Translated by H.A.R Gibb. Cambridge: Haklyut Society from the University Press, 1958-2000.

Ibn Khaldūn. The Muqaddimah: An Introduction to History, in three volumes. Translated by Franz Rosenthal. London: Routledge \& Kegan Paul, 1958.

Ibn Khaldūn. Muqaddimah, in three volumes. Edited by 'Alī 'Abd al-Wāḥid Wāfì. Cairo: Dār Nahdat Mișr li-al-nashr, 2014.

Iqbal, Muhammad. The Development of Metaphysics in Persia: A Contribution to the History of Muslim Philosophy. London: Luzac \& Co., 1908.

Jamil, Nadia. "Caliph and Qutb. Poetry as a Source for Interpreting the Transformation of the Byzantine Cross on Steps on Umayyad Coinage", Bayt al-Maqdis, Jerusalem and 
Early Islam. Oxford Studies in Islamic Art 9, Part Two. Edited by Jeremy Johns. Oxford: Oxford University Press, 1999, pp. 11-57.

Jazā'irī, 'Abd al-Qādir. Al-Mawāqif al-rūhiyyyah wa-al-fuyūụāt al-subūhiyyah, in two volumes. Edited by 'Āṣim al-Kayyālī. Beirut: Dār al-kutub al-'ilmiyyah, 2004.

J̄ilī, 'Abd al-Karīm. Al-Manāzirir al-ilāhiyyah. Edited by Najāḥ al-Ghunaymī. Cairo: Dār al-Manār, 1987.

Jīlī, 'Abd al-Karīm. Al-Insān al-kāmil fì ma 'rifat al-awākhir wa-al-awā'il. Edited by Șalāḥ ibn Muḥammad 'Uwayḍah. Beirut: Dār al-Kutub al-'ilmiyyah, 1997.

Jīlī, 'Abd al-Karīm. Al-Kamālāt al-ilāhiyyah fì al-șifāt al-muhammadiyyah. Edited by Sa'̄id 'Abd al-Fattāh. Cairo: 'Ālam al-fikr, 1997.

Jīlì, 'Abd al-Karīm. Göttliche Vollkommenheit und die Stellung des Menschen: die Sichtweise 'Abd al-Karìm al Ğìlīs auf der Grundlage des "Šarh muškilāt al-futūhāt al-makkiya”. Edited by Angelika Al-Massri. Stuttgart: Deutsche Morganländische Gesellschaft, 1998.

Jīlī, 'Abd al-Karīm. Sharh mushkilāt al-Futūhāat al-Makkiyyah. Edited by Youssef Ziedan. Cairo: Dār al-Amīn, 1999.

Jīlī, 'Abd al-Karīm. Marātib al-wujūd wa-ḥaqīqat kull mawjūd. (No editor listed.) Cairo: Maktabat al-Qāhirah, 1999.

Jīlī, 'Abd al-Karīm. Ibdā' al-kitābah wa-kitābat al-'ibdā' ('ayn 'alá al-'ayniyyah: sharh mu 'āṣir li- 'ayniyyat al-imām al-șūfì 'Abd al-Karīm al-Jīlì) [=al-Nādirāt al-'ayniyyah]. Edited and commented on by Su'ād al-Hakīm. Beirut: Dār al-Burāq, 2004.

Jīlī, 'Abd al-Karīm. I Nomi divini e il Profeta alla luce del sufismo (Al-Kamālāt al-ilāhiyyah fī al-șifāt al-muhammadiyyah). Translated by Claudio Marzullo. Turin: Il leone verde, 2015.

Johns, Anthony H. "Malay Sufism: As Illustrated in an Anonymous Collection of 17th Century Tracts", Journal of the Malayan Branch of the Royal Asiatic Society 30, no. 2 (1957), pp. 3-99.

Johns, Anthony H. "Al-Kushashī”, Encyclopaedia of Islam, second (new) edition.

Karamustafa, Ahmet. Sufism: The Formative Period. Berkeley, CA: University of California Press, 2007.

Katz, Jonathan. Dreams, Sufism, and Sainthood: The Visionary Career of Muhammad alZawâwî. Leiden: Brill, 1996.

Katz, Marion. The Birth of the Prophet Muhammad: Devotional Piety in Sunni Islam. London: Routledge, 2007.

Knysh, Alexander. Ibn 'Arabi in the Later Islamic Tradition: The Making of a Polemical Image in Medieval Islam. Albany, NY: State University of New York Press, 1999.

Knysh, Alexander. "Sufism and the Qur'ān", Encyclopaedia of the Qur'ān, online edition.

Lane, George. Early Mongol Rule in Thirteenth Century Iran: A Persan Renaissance. London: Routledge Curzon, 2003.

Lo Polito, Nicholas. 'Abd al-Karìm al-Jīlī: Tawhīid, Transcendence, and Immanence. Doctoral thesis, University of Birmingham, 2010.

McDougall, James. “ “Abd al-Qādir, Amīr”, Encyclopaedia of Islam, third edition (online).

Mahdi, Muhsin. Ibn Khaldūn's Philosophy of History: A Study in the Philosophic Foundation of the Science of Culture. London: G. Allen \& Unwin, 1957.

Margariti, Roxani E. Aden \& the Indian Ocean Trade: 150 Years in the Life of a Medieval Arabian Port. Chapel Hill, NC: University of North Carolina Press, 2007.

Markiewicz, Christopher. Crisis of Kingship in Late Medieval Islam: Persian Emigrés and the Making of Ottoman Sovereignty. Cambridge: Cambridge University Press, 2019. 
Moin, Azfar. The Millennial Sovereign: Sacred Kingship and Sainthood in Islam. New York: Columbia University Press, 2012.

Morris, James W. "Ibn 'Arabī and His Interpreters", Journal of the American Oriental Society (Michigan) 106, no. 3 (1986), pp. 539-564, 106, no. 4 (1986), pp. 733-756, 107, no. 1 (1987), pp. 101-120.

Morris, James W. "The Spiritual Ascension: Ibn 'Arabi and the Mi'raj”, Journal of the American Oriental Society (Michigan) 107, no. 4 (1987), pp. 629-652, 108, no. 1 (1988), pp. 63-77.

Morrissey, Fitzroy. "An Introduction to 'Abd al-Karīm al-Jīlì's Commentary on the Futūhāt", Maghreb Review 41, no. 4 (2016), pp. 499-526.

Nabhānī, Yūsuf. Jawāhir al-bihāer fì faḍ̂a'il al-nabī al-mukhtār, in four volumes. Edited by Muḥammad al-Ḍannāwī. Beirut: Dār al-Kutub al-'ilmiyyah, 1998.

Nettler, Ronald L. Sufi Metaphysics and Qur'ānic Prophets: Ibn 'Arabī's Thought and Method in the Fuṣuṣ al-hikam. Cambridge: Islamic Texts Society, 2003.

Nicholson, Reynold A. Studies in Islamic Mysticism. Richmond, UK: Curzon Press, 1921.

Riddell, Peter. Islam and the Malay-Indonesian World. Honolulu: University of Hawai'i Press, 2001.

Ritter, Helmut. “ “Abd al-Karīm al-Djīlì”, Encyclopaedia of Islam, second (new) edition.

Rubin, Uri. "Pre-Existence and Light: Aspects of the Concept of Nur Muhammad", Israel Oriental Studies 5 (1975), pp. 62-119.

Rubin, Uri. "Nūr Muhammadī." Encyclopaedia of Islam, second (new) edition.

Sahner, Christian C. Christian Martyrs Under Islam: Religious Violence and the Making of the Muslim World. Princeton, NJ: Princeton University Press, 2018.

Sands, Kristin Z. Süfi Commentaries on the Qur'ān in Classical Islam. London: Routledge, 2006.

Sarrāj, Abū Nașr. Kitāb al-Luma' fì al-tașawwuf. Edited by Reynold Alleyne Nicholson. Leiden: Brill, 1914.

Schimmel, Annemarie. And Muhammad is His Messenger: Veneration of the Prophet in Islamic Piety. Chapel Hill, NC; London: University of North Carolina Press, 1985.

Sells, Michael. Early Islamic Mysticism: Sufi, Qur'an, Mi'raj, Poetic and Theological Writings. New York: Paulist Press, 1996.

Shaker, Anthony F. Thinking in the Language of Reality: Sadr al-Dīn Qūnavī (1207-74 CE) and the Mystical Philosophy of Reason. USA: XLibris, 2015.

Shoshan, Boaz. Popular Culture in Medieval Cairo. Cambridge: Cambridge University Press, 1993.

Sirriyeh, Elizabeth. Sufi Visionary of Ottoman Damascus: 'Abd al-Ghanī al-Nābulusī, 1641-1731. London: Routledge, 2005.

Smith, G. Rex. "Rasulids", Encyclopaedia of Islam, second (new) edition.

Smith, G. Rex. "Tihāma", Encyclopaedia of Islam, second (new) edition.

Tahānawī, Muḥammad. Kashshāf iștilāhāât al-funūn. Edited by Luṭ̂̄i 'Abd al-Bad̄̄', 'Abd al-Mun'im Husayn, and Amīn Khūlī. Cairo: al-Mu'assasah al-Mișrīyah al-'āmmah li-lta' līf wa-al-tarjamah wa-al-țibā' ah wa-al-nashr, 1963.

Taji-Farouki, Suha. Beshara and Ibn 'Arabi: A Movement of Sufi Spirituality in the Modern World. Oxford: Anqa, 2007.

Tarjumān, Suhaylah. Naẓariyyat waḥdat al-wujūd bayn Ibn 'Arabī wa-al-Jīlī. Beirut: Manshūrāt Maktabat Khaz'al, 2002.

Todd, Richard. The Sufi Doctrine of Man: Sadr al-Dīn al-Qūnawī's Metaphysical Anthropology. Leiden: Brill, 2014. 


\section{Al-Jìl'̀'s life and thought}

Trimingham, J. Spencer. The Sufi Orders in Islam. Oxford: Clarendon Press, 1971.

Vallet, Éric. L'Arabie marchande: État et commerce sous les sultans rasūlides du Yémen (626-858/1229-1454). Paris: Publications de la Sorbonne, 2010.

van Inwagen, Peter and Meghan Sullivan. "Metaphysics", The Stanford Encyclopaedia of Philosophy, online edition.

Weismann, Itzchak. "God and the Perfect Man in the Experience of "Abd al-Qadir alJaza'iri”, Journal of the Muhyiddin Ibn 'Arabi Society 30 (2001), pp. 55-72.

Woerner-Powell, Tom. Another Road to Damascus: An Integrative Approach to 'Abd al-Qādir al-Jazā'irī. Berlin; Boston, MA: Walter de Gruyter, 2017.

Woodward, Mark. Java, Indonesia, and Islam. New York: Springer, 2010.

Yilmaz, Hüseyin. Caliphate Redefined: The Mystical Turn in Ottoman Political Thought. Princeton, NJ: Princeton University Press, 2018.

Zabīdī, al-Sharjī. Țabaqāt al-khawāṣṣ ahl al-șidq wa-al-ikhlāṣ. Sana'a; Beirut: al-Dār alYamaniyyah li-al-nashr wa-al-tawzī‘, 1986.

Ziedan, Youssef. 'Abd al-Karīm al-Jīlì: faylasūf al-șüfyyah. Cairo: al-Hay’ah al-Mișriyyah 'āmmah li-l-kitāb, 1988.

Ziedan, Youssef. Al-Fikr al-șūfì 'ind 'Abd al-Karìm al-Jìlī. Cairo: Dār al-Amīn, 1998.

Zildžić, Ahmed. Friend and Foe: The Early Ottoman Reception of Ibn 'Arabī. Doctoral thesis, University of California, Berkeley, 2012. 
by al-Qūnawī and his followers, such as the distinction between 'unqualified oneness' (al-ahadiyyah) and 'qualified oneness' (al-wāhidiyyah) (a distinction made particularly explicit by al-Farghānī) ${ }^{114}$ or the identification of the level of 'divinity' (al-ulūhiyyah) as the locus of manifestation of the divine names and attributes (as in al-Qāshān̄̄'s scheme). ${ }^{115}$

All this being said, al-Jillī's scheme is also different from and more elaborate than those of the earlier thinkers - as one would expect, given that he identifies 40 rather than just five or six levels. For instance, while al-Qūnawī and his followers, with the notable exception of al-Qāshān̄i, tend to consider the simple divine essence as being above the levels - a view that al-Jīlì does refer to in the Marātib ${ }^{116}$ - al-Jīli incorporates the imperceptible essence into his scheme. This willingness to think of the divine essence as more closely connected to the rest of existence foreshadows an important point that we shall consider in depth later in this book, namely, al-Jîlî's apparent identification of the divine essence with the Muhammadan Reality.

Another important element of al-Jîlī's elaboration of the earlier scheme is his integration of different frames of reference into a single scheme. Where al-Qūnawī and his followers put forward a scheme largely using the key Sufi metaphysical vocabulary of Ibn 'Arabī, adding a few key terms from the lexica of falsafah and kalām (e.g. ta 'ayyun, tashkīk), ${ }^{117}$ al-Jīlī integrates in a more complete way terms and concepts from Ibn 'Arabian Sufi metaphysics (e.g. absolute existence, unqualified and qualified oneness, the Perfect Human), philosophy (e.g. the primordial substance, the first and active intellect, the universal soul), the Qur'an (e.g. the throne, the footstool, the preserved tablet), and the sciences (e.g. the planets, the orbits, the elements, the humours, minerals, plants). It might therefore be said that al-Jīlì's conception of the levels of existence, being a comprehensive overview of all phenomena known to him, is less narrowly metaphysical and abstract than the schemes of al-Qūnawī and his followers.

Finally, al-Jîlī's development of the idea of the levels of existence may also be connected to the significance that he places on the idea of the Perfect Human. In identifying 40 levels that are synthesised within man, there is perhaps more of an emphasis in his scheme on the idea of man as a microcosm, an idea alluded to on several occasions in Marātib al-wujūd (e.g. in his discussion of the seven heavens, the orbits, and the Perfect Human himself), and which, as we shall see, is a key element of the idea of the Perfect Human. Certainly, his conception of the levels of existence reflects his stance vis-à-vis the earlier Ibn 'Arabian tradition more generally: while his overall perspective on reality is in agreement with theirs, nevertheless he elaborates upon the ideas found in the earlier tradition, 'correcting' them where he thinks it necessary. This feature of his thought comes out most clearly in his treatment of the idea of the Perfect Human, the main focus of his work, to which we shall now turn.

\section{Notes}

1 Compare Nicholson, Studies, 125.

2 Plotinus refers in Enneads V.I.6 to 
the question repeatedly discussed, even by the ancient philosophers, how from the One, if It is such as we say It is, a multiplicity or a duality or a number come into existence. Why did It not remain by Itself? How did so great a multitude flow from It as that which we see to exist in beings but think it right to refer back to the One?

A.H. Armstrong (tr.), Plotinus, 69.

3 While al-Jīlin, as we shall see, uses both theological and philosophical vocabulary, it is the former that dominates. Thus in the introduction to the book he states that the thing sought for ( $a l-m a t \underline{l} \bar{u} b)$ is the Real, i.e. God (al-haqq) (and not 'the One'). See al-Jīin, al-Insān, 11.

4 For the centrality of the problem of the one and the many to Ibn 'Arabī's thought, see Nettler, Sufi Metaphysics, 7-11, and to al-Qūnawī's, see Todd, Sufi Doctrine, 56.

5 The Neoplatonic background to al-Jîlî's thought can be seen in his use of certain technical terms - e.g. the first intellect (al-'aql al-awwal), the universal intellect (al-'aql al-kullī), the universal spirit (al-nafs al-kullī/al-kulliyyah) (see esp. al-Jîlī, al-Insān, 145-149; al-J̄̄lì , Marātib, 27-29), in his conception of different worlds; in his conception of man as a microcosm (on both of which see the discussion in this chapter); in his occasional references to the defilement of the body and the lower world in contrast to the purity of the spirit and the afterlife (see e.g. al-Jì $1 \overline{1}$, al-Insān, 152, 195, 200-201); and in the high esteem in which he holds Plato (see ibid., 188-189). This loose affiliation to the Neoplatonic tradition is largely a consequence of his adoption of the Sufi metaphysical perspective of Ibn 'Arabī, for whose Neoplatonic connections see F. Rosenthal, "Ibn 'Arabī between 'Philosophy' and 'Mysticism': 'Sūfism and Philosophy are Neighbors and Visit Each Other': fa-inna at-tașawwuf wa-t-tafalsuf yatajāwarāni wa-yatazāwarāni”, Oriens 31 (1988), 1-35, 5; Ebstein, Mysticism and Philosophy.

6 Cf. Nicholson, Studies, 125.

7 See Ibn 'Arabī, Fuṣūṣ al-ḥikam, ed. Abū al-'Alá 'Afîfī (Beirut: Dār al-Kitāb al-'Arabī, 1946), 49. Tajallī is not identical to the concept of emanation in the sense that the manifestation of the divine existence does not occur through a fixed series of hypostases (the One, the Intellect, the Soul, etc.), as in the classic Neoplatonic doctrine of Plotinus, or a chain of ten cosmic intellects, as in the view of the philosopher al-Fārābī (d. 950/951) and his followers. See T. Izutsu, Sufism \& Taoism: A Comparative Study of Key Philosophical Concepts (Berkeley, CA; London: University of California Press, 1984), 43-44; I.R. Netton, Allāh Transcendent: Studies in the Structure and Semiotics of Islamic Philosophy, Theology and Cosmology (London: Routledge, 1989), 269-280; S.M.N. al-Attas, The Mysticism of Hamzah Fanșūrī (Kuala Lumpur: University of Malaya Press, 1970), 72-73; Todd, Sufi Doctrine, 56-57. Furthermore, al-Jîlī also stresses that the divine act of giving existence $(a l-\bar{i} j \bar{a} d)$ is an act of free volition (al-ikhtiyār) on God's part, in contrast to the purer emanationist position that the effusion of the divine being is a necessary matter. See al-Jīlī, al-Insān, 86.

8 See Izutsu, Sufism \& Taoism, 152.

9 Al-J̄̄ilì, al-Insān, 51.

10 Ibid., 52.

11 Ibid., 54.

12 Ibid., 67.

13 Ibid., 79.

14 Ibid., 95.

15 Ibid., 97. 
16 Ibid., 104.

17 Ibid., 266, or as he also puts it: "There is no existence for anything but God ( $l \bar{a}$ wujūd li-shay' illā Allāh)."

18 Ibid., 132.

19 Ibid., 142.

20 Ibid., 143.

21 Ibid., 178.

22 Certain scholars have described the thought of Ibn 'Arabī and his followers including al-J̄̄lì - as pantheistic or monistic, while Ibn 'Arabī and his interpreters are above all associated with the idea of "the unity of existence" (wahdat al-wujüd). See e.g. Nicholson, Studies, 140-141; Abū al-'Alá al-'Afîfì, The Mystical Philosophy of Muhyid Dín Ibnul 'Arabi (Cambridge: University Press, 1939), xi; Rosenthal, "Ibn 'Arabî", 6; Knysh, Ibn 'Arabi, 281, note 28. I generally avoid using these terms, since although Ibn 'Arabians like al-Jîli believe God to be manifest in the entirety of existence, nevertheless this does not mean, as we shall see presently, that God and creation are identical, i.e. that "All is God".

23 See e.g. al-Jīlī, al-Insān, 5, 22, 52, 103, 104, 142; see also al-Jīìi, Sharh, 115. For Ibn 'Arabī's use of the same term, see e.g. Ibn 'Arabī, Les illuminations de la Mecque $=$ The Meccan Illuminations = al-Futûhât al-Makkiyya, ed. and tr. W. Chittick and M. Chodkiewicz (Paris: Sindbad, 1988), 106.

24 See e.g. al-Jīlì, al-Insān, 51, 177.

25 See e.g. ibid., 5, 130.

26 See e.g. ibid., 150-151; cf. Ibn 'Arabī, Fușūṣ, 68-69.

27 See e.g. al-J̄̄lì, al-Insān, 31, 51.

28 See e.g. ibid., 66, 142; cf. Ibn 'Arabī, Fușūss, 68.

29 See e.g. al-Jīlì, al-Insān, 61; see also al-Jīlì, Sharh,115.

30 See e.g. al-Jīlì, al-Insān, 59.

31 See e.g. ibid., 18, 23; see also al-Jīlīi, Sharh, 115; cf. Ibn 'Arabī, Fuṣūṣ, 69.

32 See e.g. al-Jî̀ī, al-Insān, 88. For this idea in Ibn 'Arabī and Andalusian Neoplatonism, see Ebstein, Mysticism and Philosophy, 33-76.

33 See e.g. al-Jīlì, al-Insān, 97.

34 See e.g. ibid., 93.

35 Mindful of the criticisms often made of Sufis, al-Jīlī also insists that the relationship between God and creation is not defined by "indwelling" (hulūl), "direct contact" (mumāssah), or "union” (ittiḥād). See e.g. ibid., 5, 52, 149, 215, 203, 255.

36 Ibid., 72

37 Ibid., 94.

38 Ibid., 51.

39 Ibid., 60.

40 See ibid., 60-61.

41 See Izutsu, Sufism \& Taoism, 48-67; Ahmed, What is Islam, 90. For al-Jîlī’s development of this Ibn 'Arabian idea in his commentary on the Futūḥăt, see Morrissey, "An Introduction". For his exposition of the same idea in his poem al-Nādirāt al-'ayniyyah, see al-Jîlì, Ibdā', 48.

42 See al-Jīlīi, al-Insān, 68. On this concept in Ibn 'Arabī’s thought, see Nettler, Sufi Metaphysics, 9-11; al-Ḥakìm, al-Mu ‘jam, 1133.

43 See al-Jìlī, al-Insān, 99. This is one of the traditional 'most beautiful names' of God, being derived from the Qur'an (see e.g. Q 2:263, 2:267, 6:133). 
44 See al-Jīlī, al-Insān, 87, 108. This is a Qur'anic idea: see Q 35:15 - “O people! You are in need of (al-fuqarā' ilá) God, but God is the Self-Sufficient (al-ghanīy), the Praiseworthy." For Ibn 'Arabī's expression of the same idea, see Ibn 'Arabī, Fuṣūss, 105-106.

45 See al-Jīlī, al-Insān, 51, 90.

46 See ibid., 88.

47 See e.g. ibid., 100, 108.

48 See ibid., 42. For Ibn Sīnā's key distinction between necessity and possibility/ contingency, the crux of his proof for the existence of God, see the useful summary and analysis in L. Goodman, Avicenna (London; New York: Routledge, 1992), 61-83.

49 See Nicholson, Studies, 152; W. Chittick, The Sufi Path of Knowledge: Ibn al'Arabi's Metaphysics of Imagination (Albany, NY: State University of New York Press, 1989), 4. See also Ibn 'Arabī, Fușūș, 106.

50 For the classic discussion of this idea in Western thought, see Lovejoy, The Great Chain of Being.

51 Chittick, Sufi Path of Knowledge, 4.

52 See W. Chittick, "The Five Divine Presences: from al-Qūnawī to al-Qayșarı̄”,, Muslim World 72, vol. 2 (1982), 107-128. For the more systematic approach of al-Qūnawī and his followers, see W. Chittick, "The Last Will and Testament of Ibn ‘Arabi's Foremost Disciple, Sadr al-Din Qunawi”, Sophia Perennis 4, no. 1 (1978), 43-58, 44; W. Chittick, "The Central Point: Qūnawî's Role in the School of Ibn 'Arabî”, Journal of the Muyiddin Ibn 'Arabi Society 35 (2004), 25-45, 26. For a slight corrective to Chittick's remarks, see Todd, Sufi Doctrine, 49.

53 Al-Qūnawī’s student Sa‘̄ìd al-Dīn al-Farghānī, for example, specifies six hadrāt. See Chittick, "Five Divine Presences", 116-120.

54 For the significance of this term and concept in the Sufi metaphysics of the Qunawi tradition, see Dagli, Ibn al- 'Arabī, 60-62, 75-80, 106-117. Though al-Jīlī does use the term occasionally (e.g. in his discussion of the fourth level of existence in Marātib al-wujūd), it does not appear to be so central a concept within his Sufi metaphysics as it is in the Qūnawi tradition.

55 See Chittick, "Five Divine Presences", 125, note 9.

56 The following is based largely on ibid., passim. See also Izutsu, Sufism \& Taoism, 11.

57 See al-Farghān̄̄, Muntahá al-madārik fì sharh Tā'iyyat Ibn al-Fārị̣, ed. A. al-Kayyālī (Beirut: Dār al-Kutub al-'ilmiyyah, 2007), 1:21: "Unity (al-waḥdah) has two primary, original aspects, one of them [is defined by] the complete falling away of perspectives on it (suqūt al-i 'tibārat 'an-hā bi-al-kulliyyah). In this aspect, the essence is called and 'unqualified one' (ahadan)."

58 See ibid., 18.

59 However, in one of his lexica of Sufi technical terms, al-Qāshānī identifies hadrat al-ahadiyyah with "the manifestation of the essence alone to itself" (tajalli al-dhāt wahdiha $l i-d h a \bar{a} i h \bar{a}$ ), implying that the essence at the level of al-ahadiyyah is distinct from the utterly unmanifest and unqualified simple essence. See al-Qāshān̄̄, Mu 'jam iștilāḥāt al-ṣüfyyah, ed. 'A. Shāhīn (Cairo: Dār al-Manār, 1992), 173. This reflects how the use of technical terms by Ibn 'Arabī and his interpreters is marked by a certain fluidity.

60 See al-Farghān̄̄, Muntahá al-madārik, 1:21: "The other aspect [of divine unity] is the affirmation of infinite perspectives within it (thubūt al-i 'tibārāt al-ghayr al-mutanāhiyyah la-hā) ... The essence in this aspect is called a 'qualified one' (wāhidan)." 
61 See Chittick, "Five Divine Presences", 122-123; Izutsu, Sufism \& Taoism, 11-20.

62 See Knysh, Ibn 'Arabi, 242-243.

63 See e.g. al-J̄ilì̄, al-Insān, 123, 155, 214; al-Jīlì, Sharh, 128; al-Jīlī, Marātib, 19, 20, $22,25$.

64 Chittick, Sufi Path of Knowledge, 14.

65 Chittick, "Five Divine Presences", 109; Todd, Sufi Doctrine, 32.

66 Chittick, "Five Divine Presences", 109.

67 For the impact of Avicennian philosophy on the thought of al-Qūnawi and al-Qāshān̄̄ in particular, see Morris, "Ibn 'Arabī”, 2:751-756. Morris sees al-Jīllì's thought as being grounded more "in his own spiritual insight and experience" than in falsafah. See ibid., 3:108.

68 See e.g. al-Jîlī, al-Insān, 61

69 See e.g. ibid., 69, 214-215.

70 See Chittick, "Five Divine Presences", 115.

71 This accords with the view of Morris, "Ibn 'Arabī", 3:108, note 92. It should also be noted that al-Jīli states in the introduction to Marātib al-wujūd that within the 40 levels there are innumerable more particular levels. In this sense the 40 levels are the "mothers of the levels" (ummuhāt al-marātib). See al-Jīlī, Marātib, 15.

72 See al-Bosnawī, Kitāb al-qirá al-rūḥ̄ al-mamdūd li-al-adyāf al-wāridīn min marātib al-wujūd, ed. 'A. Qārțāl (Bursa, no publisher listed, 1996), esp. 3, 6, 13, 16, 20, 29, 47, 49, 56, for the direct references to al-Jîlī's Marātib al-wujūd.

73 On the dating of the work, see Ziedan, 'Abd al-Karìm, 70. Al-Jìli also identifies the existence of 40 levels in his first work, al-Kahf wa-al-raqīm fì sharh bism Allāh al-rahmān al-rahìm (see Atlagh, "LE POINT", 177), to which he directs the reader of al-Insān al-kāmil who wishes to learn more about the 40 levels (see al-Jîlī, al-Insān, 219). This indicates the consistency of al-Jīlin's general metaphysical outlook over the course of his life.

74 Al-Jīlì, Marātib, 15-16.

75 Ibid., 17-18.

76 Ibid., 18-19.

77 Ibid., 19.

78 Ibid., 19-20.

79 Ibid., 20.

80 Ibid., 22.

81 Ibid., 22-24.

82 Ibid., 25.

83 Ibid.

84 Ibid., 25-26.

85 Ibid., 26.

86 Ibid., 27-28.

87 Ibid., 28-29.

88 Ibid., 29.

89 Ibid., 30.

90 Ibid., 30-31.

91 Ibid., 31.

92 Ibid., 33.

93 Ibid., 34.

94 Ibid., 35.

95 Ibid., 36. 
96 Ibid., 42.

97 Ibid., 43.

98 Ibid., 44.

99 Ibid.

100 Ibid., 44-45.

101 Ibid., 45.

102 Ibid.

103 Ibid., 45-46.

104 Ibid., 46.

105 Ibid.

106 Ibid., 46-47.

107 Ibid., 47.

108 Ibid., 47-48.

109 Ibid., 49.

110 Ibid., 49-50.

111 Ibid., 50.

112 Ibid., 51-53.

113 Ibid., 53-54.

114 See ibid., 17-18.

115 See ibid., 19.

116 See ibid., 16.

117 See Todd, Sufi Doctrine, 46; Dagli, Ibn al- 'Arabī, 60-67.

\section{Bibliography}

'Afĩfì, Abū al-'Alá. The Mystical Philosophy of Muhyid Dín Ibnul 'Arabí. Cambridge: University Press, 1939.

Ahmed, Shahab. What is Islam? The Importance of Being Islamic. Princeton, NJ: Princeton University Press, 2016.

Armstrong, A.H. (translator). Plotinus. London: George Allen \& Unwin Ltd., 1953.

Atlagh, Riyadh. "LE POINT ET LA LIGNE: Explication de la Basmala par la science des lettres chez 'Abd al-Karīm al-Ğ̄ilī (m. 826 h.)", Bulletin d'études orientales 44, SCIENCES OCCULTES ET ISLAM (1992), pp. 161-190.

Attas, Syed M.N. The Mysticism of Hamzah Fanșūrī. Kuala Lumpur: University of Malaya Press, 1970.

Bosnawī, 'Abd Allāh. Kitāb al-qirá al-rūḥ̄ al-mamdūd li-al-aḍā̄f al-wāridīn min marātib al-wujūd. Edited by 'Abd Allāh Qārțāl. Bursa, no publisher listed, 1996.

Chittick, William C. "The Last Will and Testament of Ibn 'Arabi's Foremost Disciple, Sadr al-Din Qunawi”, Sophia Perennis 4, no. 1 (1978), pp. 43-58.

Chittick, William C. "The Five Divine Presences: From al-Qūnawī to al-Qayșarı̄”,, Muslim World 72, no. 2 (1982), pp. 107-128.

Chittick, William C. The Sufi Path of Knowledge: Ibn al- 'Arabi's Metaphysics of Imagination. Albany, NY: State University of New York Press, 1989.

Chittick, William C. "The Central Point: Qūnawî's Role in the School of Ibn 'Arabî”, Journal of the Muyiddin Ibn 'Arabi Society 35 (2004), pp. 25-45.

Dagli, Caner. Ibn al- 'Arabī and Islamic Intellectual Culture: From Mysticism to Philosophy. London: Routledge, 2016.

Ebstein, Michael. Mysticism and Philosophy in al-Andalus: Ibn Masarra, Ibn al-'Arabī and the Ismā ‘̂̀lì Tradition. Leiden: Brill, 2014. 
Farghānī, Sa‘d al-Dīn. Muntahá al-madārik fì sharh Tā'iyyat Ibn al-Fāriḍ. Edited by 'Āṣim al-Kayyālī. Beirut: Dār al-Kutub al-'ilmiyyah, 2007.

Goodman, Lenn E. Avicenna. London; New York: Routledge, 1992.

Ḥakīm, Su'ād. Al-Mu'jam al-ṣūfì: al-hikmah fì ḥudūd al-kalimah. Beirut: Dandarah li-al-țabā'ah wa-al-nashr, 1981.

Ibn 'Arabī. Fuṣūṣ al-ḥikam. Edited by Abū al-'Alá 'Afĩfì. Beirut: Dār al-Kitāb al-'Arab̄̄, 1946.

Ibn 'Arabī. Les illuminations de la Mecque=The Meccan Illuminations=al-Futûhât alMakkiyya. Edited and translated by William Chittick and Michel Chodkiewicz. Paris: Sindbad, 1988.

Izutsu, Toshihiko. Sufism \& Taoism: A Comparative Study of Key Philosophical Concepts. Berkeley, CA; London: University of California Press, 1984.

Jīlī, 'Abd al-Karīm. Al-Insān al-kāmil fì ma'rifat al-awākhir wa-al-awā'il. Edited by Șalāh ibn Muhammad 'Uwayḍah. Beirut: Dār al-Kutub al-'ilmiyyah, 1997.

Jīlī, 'Abd al-Karīm. Sharh mushkilāt al-Futūhāat al-Makkiyyah. Edited by Youssef Ziedan. Cairo: Dār al-Amīn, 1999.

Jīlì, 'Abd al-Karīm. Marātib al-wujūd wa-haqīqat kull mawjūd. (No editor listed.) Cairo: Maktabat al-Qāhirah, 1999.

Jīlī, 'Abd al-Karīm. Ibdā' al-kitābah wa-kitābat al- 'ibdā' ('ayn 'alá al-'ayniyyah: sharh mu'āṣir li- 'ayniyyat al-imām al-șüfì 'Abd al-Karìm al-Jìlī) [=al-Nādirāt al-'ayniyyah]. Edited and commented on by Su'ād al-Ḥakīm. Beirut: Dār al-Burāq, 2004.

Knysh, Alexander. Ibn 'Arabi in the Later Islamic Tradition: The Making of a Polemical Image in Medieval Islam. Albany, NY: State University of New York Press, 1999.

Lovejoy, Arthur. The Great Chain of Being: A Study of the History of an Idea. Cambridge, MA; London: Harvard University Press, 2001.

Morris, James W. "Ibn 'Arabī and His Interpreters", Journal of the American Oriental Society (Michigan) 106, no. 3 (1986), pp. 539-564, 106, no. 4 (1986), pp. 733-756, 107, no. 1 (1987), pp. 101-120.

Morrissey, Fitzroy. "An Introduction to 'Abd al-Karīm al-Jīlì's Commentary on the Futūhāt", Maghreb Review 41, no. 4 (2016), pp. 499-526.

Nettler, Ronald L. Sufi Metaphysics and Qur'ānic Prophets: Ibn 'Arabī's Thought and Method in the Fuṣuṣ al-hikam. Cambridge: Islamic Texts Society, 2003.

Netton, Ian R. Allāh Transcendent: Studies in the Structure and Semiotics of Islamic Philosophy, Theology and Cosmology. London: Routledge, 1989.

Nicholson, Reynold A. Studies in Islamic Mysticism. Richmond, UK: Curzon Press, 1921.

Qāshānī, 'Abd al-Razzāq. Mu 'jam iṣtiliāhāt al-șūfiyyah. Edited by 'Abd al-'Āl Shāhīn. Cairo: Dār al-Manār, 1992.

Rosenthal, Franz. 'Ibn 'Arabī between 'Philosophy' and 'Mysticism': 'Sūfism and Philosophy are Neighbors and Visit Each Other'. fa-inna at-tașawwuf wa-t-tafalsuf yatajāwarāni wa-yatazāwarāni”, Oriens 31 (1988), pp. 1-35.

Todd, Richard. The Sufi Doctrine of Man: Sadr al-Dīn al-Qūnawì's Metaphysical Anthropology. Leiden: Brill, 2014.

Ziedan, Youssef. 'Abd al-Karīm al-Jīlī: faylasūf al-șüfiyyah. Cairo: al-Hay'ah al-Mișriyyah 'āmmah li-l-kitāb, 1988. 
(al-imām al-bātin) to be infallible (maș̣um), but not of the 'Apparent' [Imam]", ${ }^{119}$ in the context of an attack on the Shi'i conception of the Imamate. As is typical of his approach, in al-Insān al-kāmil al-Jīlì both makes this Ibn 'Arabian idea more explicit and introduces new elements into the discussion. The effect of this is that he presents us with an unambiguous conception of the Perfect Human as a sinless individual within a sinful world.

\section{Notes}

1 See G. Böwering and Y. Casewit, A Qur'an Commentary by Ibn Barrajān of Seville (d. 536/1141): Ị̇̄hh al-hikma bi-ahkām al-ibra (Wisdom Deciphered, the Unseen Discovered) (Leiden: Brill, 2015), 40-43; Y. Casewit, The Mystics of al-Andalus: Ibn Barrajān and Islamic Thought in the Twelfth Century (Cambridge: Cambridge University Press, 2018), 172ff. Ibn Barrajān's notion of the Universal Servant may have been derived from the Brethren of Purity. See S.H. Nasr, An Introduction to Islamic Cosmological Doctrines (Albany, NY: State University of New York Press, 1993), 68.

2 Y. Ibn 'Adī, Tahdhīb al-akhlāq, ed. S. al-Yasū'ì (Silsilat Rawā'i' al-turāth al-'arabī al-masīḥ̄, n.d.), 128-138; Y. Ibn 'Ad̄̄, The Reformation of Morals, ed. and tr. S. Griffith (Provo, UT: Brigham Young University Press, 2002), xxxviii-xli, 92-99.

3 M. Maimonides, The Guide of the Perplexed, in two volumes (Chicago, IL: University of Chicago Press, 1963), tr. S. Pines, 1:49 [I 21].

4 Thus according to Yahyá, the complete humans are those with perfect morals $(a k h l \bar{a} q)$, meaning that, in true Aristotelian fashion, they cultivate moderation (al-i 'tidāl) and avoid extremes (al-ifra $\bar{t}$ ). The way to achieve such perfection is "theoretical contemplation of the true [namely, Aristotelian] sciences and sitting with people of knowledge (al-nazar fì al-'ulūm al-haqīqiyyah wa-mujālasat ahl al-'ilm)". Ibn 'Adī, Tahdhīb al-akhlāq, 128-130; Ibn 'Adī, Reformation of Morals, 94-95. As for Maimonides, his conception of human perfection has been the subject of much scholarly disagreement. Menachem Kellner has, I think, quite convincingly argued that Maimonides thought that intellectual perfection must be followed (at least for Jews) by "halakhic perfection", that is, the imitation of God's actions through the perfect fulfilment of His commandments (mitsvōt). See M. Kellner, Maimonides on Human Perfection (Atlanta, GA: Scholars Press, 1990). The views of both Ibn 'Adī and Maimonides are rooted in the thought of al-Fārābī (d. 950/951), who "would consider neither the pure philosopher like Plotinus nor the man of action alone as perfect specimens of the human race but only the man who is both". R. Walzer, "Al-Fārābī's Theory of Prophecy and Divination", Journal of Hellenic Studies 77, no. 1 (1957), 142-148, 147.

5 G. Böwering, Encyclopaedia Iranica (online edition), s.v. "ENSĀN-E KĀMEL"; J. Nūrbakhsh, Farhang-i Nūrbakhsh (iștilāhāt-i taṣawwuf), in eight volumes (Tehran: Chāpkhāneh-yi Marvī, 1371 SH [=1992/1993]), 6:76, 138. (I am grateful to Ufuk Öztürk for lending me his copy of this work.)

6 For a comprehensive treatment of this chapter of the Fușūs, see Nettler, Sufi Metaphysics, 17-24.

7 Ibn 'Arabī, Fușūṣ, 48-49.

8 This image recalls David's request in Psalm 17:8: “Keep me as the apple (ke-īshōn) of Your eye." See also Deut. 32:10, Prov. 7:2. The Hebrew word ishōn means 'pupil' and is the diminutive of $\bar{\imath} s$, the Hebrew word for 'man', thus denoting 'the 
little man of the eye'. See L. Köhler, W. Baumgartner, M.E.J. Richardson, and J.J. Stamm, The Hebrew and Aramaic Lexicon of the Old Testament, in five volumes (Leiden: Brill, 1994-2000), 1:44.

9 Ibn 'Arabī, Fușūss, 50.

10 See ibid..

11 Ibid.

12 Ibid., 199. See also Takeshita, Ibn 'Arabī's Theory, 66.

13 This hadith and its variants appear in M. Bukhārī, Le recueil des traditions mahométanes, in four volumes, ed. L. Krehl (Leiden: Brill, 1862), 4:165-166; A.H. Muslim, Sahịh Muslim, 18 volumes in 9, ed. M. 'Abd al-Bāqī (Beirut: Dār al-kutub al'ilmiyyah, 1995), 17:147 (no. 2841). For the different variants of the hadith and their chains of transmission, as well as a discussion of early theological debates concerning the report, see C. Melchert, "God Created Adam in His Image", Journal of Qur'anic Studies 13, no. 1 (2011), 113-124. For short discussions of its interpretation in Islamic theology, see M.J. Kister, "Ādam: A Study of Some Legends in Tafsīr and Hadī $\underline{t}$ Literature", Israel Oriental Studies 13 (1993), 113-174, 137-138; Takeshita, Ibn 'Arabī's Theory, 15-17. For Ibn 'Arabī and his interpreters' use of this hadith, see e.g. Ibn 'Arabī, Fușūss, 199, 216; Ibn 'Arabī, al-Futūḥāt al-Makkiyyah, in four volumes (Egypt: Dār al-Kutub al-'arabiyyah al-kubrá, 1329 AH [=1911]), 1:680, 2:4, 2:391; al-Qāshānī, Sharḥ 'alá Fuṣūṣ al-ḥikam (Egypt: al-Maṭba'ah al-Yamaniyyah, n.d.), 11.

14 This was recognised by certain Muslim commentators. See Kister, "Ādam”, 138; J. van Ess, Theology and Society in the Second and Third Centuries of the Hijra, in four volumes, tr. G. Goldbloom (Leiden; Boston, MA: Brill, 2017), 4:421.

15 For the different ways in which the homo imago dei motif has been interpreted in Jewish and Christian theology, see A. Altmann, "Homo Imago Dei in Jewish and Christian Theology", Journal of Religion 48, no. 3 (1968), 235-259.

16 For these, see ibid., 240-246.

17 The homo imago dei motif was also controversial in Jewish thought. See e.g. Maimonides, Guide, 1:21 [1:1], where he warns against interpreting Gen. 1:26 as an indication of the corporeality of God - a warning that is one of the main themes of the Guide.

18 See al-Hallāj, Kitāb al-Tawās̄̄n, ed. and tr. L. Massignon (Paris: Librarie Paul Geuthner, 1913), 129, note 2; Kister, "Ādam", 138; van Ess, Theology and Society, 4:427-428. For an example of such an interpretation, see A. Bayḍāwī and M. Ișfahān̄̄ (comm.), Nature, Man and God in Medieval Islam, in two volumes, ed. and tr. E.E. Calverley and J.W. Pollock (Leiden: Brill, 2001-2002), 2:756, note 28. Attempts to explain away the apparent anthropomorphic content of the hadith are also found in early Imami Shi'i literature. See M.A. Amir-Moezzi, The Spirituality of Shi 'i Islam: Beliefs and Practices (London: I.B. Tauris, 2011), 119, note 45.

19 See Nicholson, Studies, 80; al-Ghazālī, Mishkāt al-anwār, ed. A. 'Afîfī (Cairo: al-Dār al-Qawmiyyah li-al-țibā'ah wa-al-nashr, 1964), 71. Al-Ghazālī prefers the reading that God created Adam "according to the form of the All-Merciful ('alá sürat al-rahmānn".

20 See Takeshita, Ibn 'Arabì's Theory, 67, quoting the Futūhăt: "All the Divine Names are bound to him [man=Adam] without one single exception. Thus, Adam came out in the image of the Name Allāh, because this name comprises all the Divine Names." See also W. Chittick, "The Chapter Headings of the Fusûs", Journal of the Muhyiddin Ibn 'Arabi Society 2 (1984), 41-94, 49.

21 For earlier treatments of Ibn 'Arabī's idea of the microcosm, see Afífì, Mystical Philosophy, 82; Izutsu, Sufism \& Taoism, 218-246; Takeshita, Ibn 'Arabì's Theory, 
100-108; Chittick, Sufi Path of Knowledge, 16-17; N.H. Abū Zayd, Falsafat al-ta'wìl: dirāsah fì ta'wīl al-Qur'ān 'ind Muhyī al-dīn Ibn 'Arabī (Beirut: Dār al-Tanwīr, 1983), 157-175; Abū Zayd, Hākadhā, 231-234; Ebstein, Mysticism and Philosophy, 170-171, 198-200.

22 R. Allers, "MICROCOSMUS: From Anaximandros to Paracelsus", Traditio 2 (1944), 319-407, 321. Allers' article, the classic study of the history of the idea of the microcosm, identifies and discusses six different formulations of the idea in Western philosophical literature.

23 See M. Hodgson, The Order of the Assassins: The Struggle of the Early Nizârî Ismâil îs against the Islamic World ('s-Gravenhage: Mouton \& Co., 1955), 10; 'Afîfi, Mystical Philosophy, 188; Nasr, Islamic Cosmological Doctrines, 66-74; Takeshita, Ibn 'Arabī's Theory, 74-92; Todd, Sufi Doctrine, 3-5, 33; Ebstein, Mysticism and Philosophy, 169, 189-198; E. Krinis, "The Philosophical and Theosophical Interpretations of the Microcosm-Macrocosm Analogy in Ikhwān aș-Ṣafä' and Jewish Medieval Writings", L'Ésoterisme Shi 'ite: ses racines et ses prolongements, ed. M. Amir-Moezzi, M. De Cillis, D. De Smet and O. Mir-Kasimov (Turnhout: Brepols, 2016), 395-409.

24 See Takeshita, Ibn 'Arabī's Theory, 92; al-Ghazālī, Kitāb-i Kìmīyā-yi sa 'ādat, ed. A. Ārām (Tehran: Chapkhānah-yi Markazī, 1954), 34-35; al-Ghazālī, Mishkāt al-anwār, 71.

25 Al-Ghazālī, Mishkāt al-anwār, 71.

26 Ibn 'Arabī, Fuṣūṣ, 49.

27 Ibid., 49.

28 Ibid., 50.

29 Ibn 'Arabī, Futūhāt, 1:216. See also Takeshita, Ibn 'Arabì's Theory, 101.

30 Ibn 'Arabī, Fuṣ̄ūs 49.

31 Ibid., 48. See also Izutsu, Sufism \& Taoism, 208; Nettler, Sufi Metaphysics, 18, 21.

32 Ibn 'Arabī, Fușūṣ, 55.

33 Ibn 'Arabī, Futūhāat, 2:464; Takeshita, Ibn 'Arabì's Theory, 110.

34 Ibn 'Arabī had himself already made this point, drawing an analogy with the letters. See Ibn 'Arabī, Futūhāt, 2:396: "The human being encompasses all of the levels through his level, just as the letter wāw encompasses all of the other letters."

35 Al-Qūnawī, Miftāh ghayb al-jam 'wa-al-wujūd, ed. A. al-Kayyālī (Beirut: Dār alKutub al-'ilmiyyah, 2010), 82.

36 Al-Qayșarī, Sharh-i muqaddamah- 'i Qayșarī bar Fușūṣ al-ḥikam-i Muhȳi al-Dīn 'Arabī, ed. J. Āshtiyānī (Mashhad: Kitābfurūshī-yi bāstān, 1350 SH [=1966]), 273.

37 See al-Qūnawī, I'jāz al-bayān fì tafsīr umm al-Qur'ān, ed. J. Āshtiyānī (Qom: Mu'assasah-yi Būstān-i Kitāb-i Qom, 1380 SH/1423 AH [=2002]), 10: "and [the Real] made the Perfect Human - who is the microcosm with respect to his form - a mediating book (kitāban wasațan) that synthesises the plane of the names and the plane of the named".

38 Ibn 'Arabī, for instance, uses the term "little Qur'an" (Qur'ān șaghīr) to denote the Perfect Human, and in one instance even identifies himself with the Qur'an and the 'seven oft-repeated verses' (al-sab 'al-mathānì), i.e. the Fätihah. See al-Hakīm, alMu 'jam, 908; Abū Zayd, Hākadhā, 48-49.

39 See e.g. al-Qāshān̄̄, Sharh, 266; al-Qāshān̄̄, Mu'jam, 11: "Man is a summary (mukhtașar) of the divine presence."

40 S. Bashier, Ibn al-'Arabī's Barzakh: The Concept of the Limit and the Relationship between God and the World (Albany, NY: State University of New York Press, 2004), 7. See also Chittick, Sufi Path of Knowledge, 117-118; al-Hakīm, al-Mu 'jam, 191-196. 
41 Quoted in Jāmī, Sharh al-Jāmī 'alá Fuṣūṣ al-ḥikam, ed. A al-Kayyālī (Beirut: Dār al-Kutub al-'ilmiyyah, 2004), 57; Tahānawī, Kashshāf, 281. See also Todd, Sufi Doctrine, 95-98; al-Qūnawī, I'jāzz, 113; Chittick, "Chapter Headings", 49-50.

42 Farghān̄̄, Muntahá al-madārik, 36. See also ibid., 84-86, 95-96, 99.

43 Al-Qāshānī, Sharh, 11. See also ibid., 268:

He [Muhammad] is this "most-perfect" through [his] synthesising (jāmi ${ }^{\circ}$ of unqualified oneness (al-ahadiyyah), evenness (shaf'iyyah), and oddness (al-watriyyah), i.e. the qualified oneness (al-wāhidiyyah) that is the essence, the attribute, and the name. In their technical terminology it is called the greatest reality of realities (haqūqat al-haqā'iq al-kubrá) and the synthetic isthmus (al-barzakh al-jāmi ) and the real Adam and the one source.

44 For this term, see al-Ḥakīm, al-Mu 'jam, 276; al-Tahānawī, Kashshāf, 1474; Chodkiewicz, Seal, 70.

45 Al-Qayșarī, Sharḥ-i muqaddamah, 475.

46 See e.g. al-Zarkashī, al-Burhān fì 'ulūm al-Qur'ān, in four volumes (Cairo: Dār al-Turāth, 1984), 2:181-182.

47 Al-Jīlì, Marātib, 53-54.

48 Al-J̄̄ilì, al-Insān, 212.

49 See also ibid., 228-252, where, in the chapter on the seven heavens, al-Jîli maps out the correspondences between the seven heavens, the seven planets, the seven names of the divine self, the seven greatest angels, the seven greatest prophets, and the seven faculties in man.

50 See e.g. Takeshita, Ibn 'Arabī's Theory, 89, 93, 99; Ebstein, Mysticism and Philosophy, 189-198.

51 See Ebstein, Mysticism and Philosophy, 198-199.

52 See Takeshita, Ibn 'Arabī's Theory, 89-90.

53 Al-Jīlì al-Insān, 212.

54 For a full list of the names of the essence, see ibid., 96.

55 Ibid., 213.

56 Ibid.

57 The concept of the walìy, pl. awliya ' - a term sometimes translated as 'saint', goes back to the Qur'an: 'The friends of God (awliyā' Allāh) have no fear, nor are they sorrowful" (Q 10:292). The manuals of classical Sufism contain discussions on the meaning of the term. Thus al-Qushayrī, for instance, explains that the term

has two meanings: one of them has a passive sense, he [namely, the waliy] being the one who is entrusted (yatawallá) with God's command ... The other has strongly active sense, he being the one who undertakes (yatawallá) the worship of God and obedience to Him ('ibādat Allāh wa-țā'atahu), such that his worship is continuous, without any disobedience intervening. And both of these two descriptions are necessary for the Friend of God to be a Friend of God.

Al-Qushayrī, al-Risālah al-Qushayriyyah, ed. K. al-Manșūr (Beirut: Dār al-Kutub al-'ilmiyyah, 2001), 292. For other definitions of the waliy in classical Sufi literature, see Nūrbakhsh, Farhang, 6:66-68. The concept is extremely prevalent in the writings of Ibn 'Arabī, who as we shall see elevates the Friend of God to the status of 'general prophet'.

58 See al-Jīlī, al-Insān, 77-78.

59 Ibid., 116-117. See also a very similar passage in al-Kamālāt, 231. 
60 Compare his statement to the definition of Sufism attributed to the Baghdadi Sufi of the classical period Abū Bakr al-Shiblī: "It is the annihilation of the humanity (fanā'-i

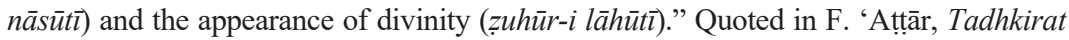
al-awliyā', ed. M. Isti' lāmī (Tehran: Intishārāt-i Zawār, 1392 SH [=2013]), 551. Note as well the statement of the Baghdadi Sufi, and friend of al-Hallāj, Ibn 'Ațā' (d. 921/922) to the effect that remembrance of God (dhikr) will lead to the "effacement of humanness" (izāl al-bashariyyah), cited in al-Sarrāj, Kitāb al-Luma', 219. In this regard, al-Jîlin's position seems to correspond more to the ideas found among the so-called 'intoxicated' Sufis of the classical period than to the Sufi metaphysics of the Ibn 'Arabian tradition. The prevalence of such ideas is indicated by the fact that al-Sarrāj devotes a short chapter of his manual to 'Mentioning those who have erred with regard to the passing away of humanness' (fanā' al-bashariyyah). See ibid., 427. According to Christopher Melchert, it seems as if al-Sarrāj "believes in the experience [of the passing away of humanness, or 'human nature'] but wants mystics not to describe it in language obnoxious to the ascetical-minded orthodox, jealous of divine transcendence". C. Melchert, "Origins and Early Sufism", Cambridge Companion to Sufism, ed. L. Ridgeon (Cambridge: Cambridge University Press, 2014), 1-23, 21.

61 Cf. al-Ghazālī, Kìmìy ā-yi sa'âdat, 25: "This [perfect primordial nature (fitrah)] is not specific to the Prophet, since the Prophet is also a human being ( $\bar{a}$ dam $\bar{l})$ : 'Say: "I am a human like you" (Q 41:6)." And see also, in a modern context, the statement of the current Grand Mufti of Egypt Ali Gomaa:

It is ... impermissible to negate the Messenger of God's humanity [s], because this would conflict with the Qur'an's words, Say: I am but a human being like you who receives revelation [41:6]. The safe approach is to affirm all that God has affirmed concerning the Messenger of God [s], such as him being light as well as being human, without going into details and debate.

A. Gomaa, Responding From the Tradition: One Hundred Contemporary Fatwas by the Grand Mufti of Egypt, tr. N. Friedlander and T. Elgawhary (Louisville, KY: Fons Vitae, 2011), 145.

62 Qayșarī, Sharh-i muqaddamah, 475.

63 Ibid.

64 See e.g. al-Qāshānī, Sharḥ, 275: "[Muhammad] synthesised Real-ness (al-ḥaqqiyyah) and createdness (al-khalqiyyah), and necessity (al-wujūb) and contingency (al-imkān), but the category of createdness and contingency was what dominated over him (al-ghālib 'alayhi)."

65 For this philosophical conception, see F. Rahman, Prophecy in Islam: Philosophy and Orthodoxy (London: George Allen \& Unwin Ltd, 1958). For Ibn Khaldūn's adherence to something close to this view, see Mahdi, Ibn Khaldûn's, 88-91, esp. 88, note 3: "There is probably no more decisive indication of Ibn Khaldûn's philosophic interpretation of the phenomena of prophecy than his identification of the 'angels' with the 'pure intellects'."

66 Ibn Khaldūn, Muqaddimah, 1:413.

67 Ibid., 1:415. See also Ibn Khaldūn, The Muqaddimah, 3:199.

68 Al-Hallāj, Kitāb al-Tawāsin, 14. Cf. Ibn 'Arabī's aforementioned phrase huwa lā huwa.

69 M. Iqbal, "The Doctrine of Absolute Unity as Expounded by Abdul Karim Jilani”, Speeches, Writings and Statements of Iqbal, in two volumes, ed. Ahmad Shirwani (Lahore: Iqbal Academy Pakistan, 2015), 1:95.

70 See I. Goldziher, Introduction to Islamic Theology and Law, tr. A. and R. Hamori, with introduction and notes by B. Lewis (Princeton, NJ: Princeton University Press, 1981), 113. 
71 Al-Jīilì, al-Insān, 126.

72 See al-Hakīm, al-Mu jam, 876-878, 909-911; al-Tahānawī, Kashshāf, 1327-1330; Chodkiewicz, Seal, 89-98.

73 See al- Jīlì, al-Insān, 210.

74 For Ibn 'Arabī's association of tașarruf with karāmah, see al-Hākim, al-Mu'jam, 694. It should be noted that in Islamic literature, the term karāmāt is normally used for the miracles of the awliya ', in contrast to mu ' $j i z \bar{a} t$, the miracles of the prophets. See L. Gardet, $E I^{2}$, s.v. "Karāma"; Hujwīrī, Kashf al-mahjūb: The Oldest Persian Treatise on Súfiism, tr. R.A. Nicholson. Leiden: Brill, 1911), 218-235; al-Ghazālī, Kìmīyā-yi sa 'ādat, 25; Ibn Khaldūn, Muqaddimah, 1:408-409.

75 See al-Jîlī, Sharh, 152-153.

76 I have not been able to find the statement that al-Jīli here attributes to al-Shibli in any of the Sufi hagiographies or collections of ecstatic utterances (shatahät), such as Farīd al-dīn 'Ațtāre's Tadhkirat al-awliyā' or the Sharh-i shathiyyāt of Rūzbihān Baqlī (d. 1209). Nevertheless, the statement is in keeping with the general tenor of the Sufi tradition's view of al-Shiblī as an ecstatic mystic prone to openly revealing the mystery of the manifestation of God in man (and in this case, in himself). For al-Shiblī, see F. Sobieroj, $E I^{2}$, s.v. "al-S_h_iblī", and the passage from "Atțār quoted below.

77 This is a reference to chapter eight of the Futūhăt, "On the knowledge of the Earth which was created from what remained of the leaven of Adam's clay, and which is the Earth of True Reality, mentioning the strange things and marvels it contains". See H. Corbin, Spiritual Body and Celestial Earth: From Mazdean Iran to Shī'ite Iran, tr. N Pearson (Princeton, NJ: Princeton University Press, 1977), 135-143.

78 See al-Jīlì, al-Insān, 72.

79 See van Ess, Theology and Society, 4:408.

80 Note, therefore, its similarity to the prayer of "Abd al-Qādir al-Jīlānī: "Not an atom moves but by His permission." Quoted in C. Padwick, Muslim Devotions (Oxford: Oneworld, 1996), 249.

81 Al-Jīlī, al-Insān, 215.

82 For the hadith, see Bukhārī, Le recueil, 4:231. For Ibn 'Arabī's use of this hadìth $q u d s \bar{\imath}$, see W.A. Graham, Divine Word and Prophetic Word in Early Islam: A Reconsideration of the Sources, With Special Reference to the Divine Saying or Hadith qudsî (The Hague: Mouton, 1977), 173-174; Chittick, Sufi Path of Knowledge, 176, 325-330; Ibn 'Arabī, Fușūs, 110. For use of this hadith in Sufism more generally, see Graham, Divine Word, 173; A. Schimmel, Mystical Dimensions of Islam (Chapel Hill, NC: University of North Carolina Press, 1975), 43; al-Ghazālī, Mishkāt al-anwār, 61-62.

83 See also al-Jīlì, al-Insān, 269, 278, where he makes an explicit connection between this hadìth qudsī, the seven attributes of the divine self, and the Perfect Human's miraculous powers.

84 Ibid., 152.

85 See ibid., 120, where al-Jīlì mentions Jesus' performance of these miracles.

86 For the Gospel accounts, see Mark 6:45-53, Matthew 14:22-34, John 6:15-21. For the appearance of this story in medieval Islamic literature, see T. Khalidi, The Muslim Jesus: Sayings and Stories in Islamic Literature (Cambridge, MA; London: Harvard University Press, 2001), 111.

87 Compare Ibn 'Arabī, Fușūss, 143, where he notes that other humans than Jesus, such as the famous Sufi Abū Yazīd al-Bisțāmī, possessed the capacity to revive the dead by breathing the divine spirit into them. 
88 Al-Jīlī, al-Insān, 196-197. Cf. Ibn Khaldūn, Muqaddimah, 1:409.

89 Al-J̄ilì, al-Insān, 195.

90 Although the Qur'an contains several scattered references to the Fall of Adam and Eve, it is often said that there is no doctrine of original sin in Islam. See A.H. Johns, Encyclopaedia of the Qur'ān, s.v. "Fall of Man". Nevertheless, al-Jīlī does appear to be describing something very like a doctrine of original sin here. There was some precedent for this in the writings of the Andalusian Sufis Ibn Barrajān and Ibn Qas̄̄ (d. 1151). See Casewit, Mystics of al-Andalus, 253-254; M. Ebstein, "Was Ibn Qasī a Șūfî?" Studia Islamica 110 (2015), 196-232, 215-217.

91 Al-Jīlì̄, al-Insān, 200.

92 Ibid., 195.

93 Ibid.

94 Ibid., 200.

95 It should be noted that in chapter 63 of al-Insān al-kāmil al-Jîli identifies as the 'philosophers' (al-falāsifah) as the group (țā'ifah) that worships the planets. See ibid., 207.

96 Ibid., 200-201.

97 Ibid., 201.

98 Ibid., 201-202.

99 Ibid., 202.

100 Ibid.

101 Ibid., 202-203.

102 Ibid., 203.

103 Ibid., 205.

104 On this point see al-'Afifi, Mystical Philosophy, 158; Schimmel, Mystical Dimensions, 273; Nettler, Sufi Metaphysics, 11-13; Ahmed, What is Islam?, 29-30.

105 Thus Shahab Ahmed, for instance, cites the famous Persian Sufi poetic phrase "All is He" (hameh üst) in his description of Ibn 'Arabī's Sufi metaphysical worldview. See Ahmed, What is Islam?, 28. See also the examples cited above from Nicholson, 'Afïfi, Rosenthal, and Knysh.

106 See e.g. al-'Afífì, Mystical Philosophy, 158.

107 See e.g. B. Radtke and J. O'Kane, The Concept of Sainthood in Early Islamic Mysticism: Two Works by al-Hakìm al-Tirmidhī (Richmond, UK: Curzon Press, 1996), 45ff., 255 s.v. nafs; Hujwīrī, Kashf al-mahjūūb, 196-207; al-Qushayrī, al-Risālah, 123; al-Ghazālī, Al-Ghazālì on Disciplining the Soul \& On Breaking the Two Desires: Books XXII and XIII of the Revival of the Religious Sciences (Ihyā' 'ulūm al-dīn), tr. T. Winter (Cambridge; Islamic Texts Society, 2016).

108 Ibn 'Arabī, Futūhāat, 1:157-158.

109 Ibid., 3:143.

110 See W. Chittick, The Self-Disclosure of God: Principles of Ibn al-'Arabī's Cosmology (Albany, NY: State University of New York Press, 1998), 270.

111 Ibn 'Arabī, Futūḥāt, 2:568.

112 Al-Qushayrī, al-Risālah, 123.

113 Al-Jīlī, al-Insān, 196. See also ibid., 192.

114 See N. Taleb, Antifragile: How to Live in a World We Don't Understand (London: Allen Lane, 2012). Taleb defines the antifragile as that which is neither fragile nor robust, but rather "gains from disorder".

115 Al-Jîlī, al-Insān, 205.

116 Ibid., 151-152. 
117 See e.g. Q 3:14, 7:81, 27:55, 52:22, 56:21, 77:42. Ibn 'Arabī, it should be noted, connects the term bashar with man's "animality" (hayawāniyyah), a term that likewise connotes sinful behaviour. See Izutsu, Sufism \& Taoism, 183.

118 See W. Madelung, $E I^{2}$, s.v. "Ișmah”; Goldziher, Introduction, 186-187; S. Schmidtke, The Theology of al-'Allāma al-Hillī (d. 726/1325) (Berlin: Klaus Schwarz Verlag, 1991), 142-147. It should also be noted that, according to the classical Sufi conception of walayyah, the Friends of God were believed to be "preserved" (mahzūur) from sin, a lower category of infallibility than 'iṣmah, yet a form of infallibility all the same. See al-Qushayrī, al-Risālah, 292.

119 Ibn 'Arabī, Futūḥāt, 3:183. See also Afìfì, Mystical Philosophy, 75.

\section{Bibliography}

Abū Zayd, Nașr H. Falsafat al-ta'wīl: dirāsah fì ta'wìl al-Qur'ān 'ind Muhyī al-dīn Ibn 'Arabī. Beirut: Dār al-Tanwīr, 1983.

Abū Zayd, Nașr H. Hākadhā takallama Ibn 'Arabì. Casablanca; Beirut: Dār al-Thaqāầ al-'Arabī, 2006.

'Afīfì, Abū al-'Alá. The Mystical Philosophy of Muhyid Dín Ibnul 'Arabí. Cambridge: University Press, 1939.

Allers, Rudolf. "MICROCOSMUS: From Anaximandros to Paracelsus", Traditio 2 (1944), pp. 319-407.

Altmann, Alexander. "Homo Imago Dei in Jewish and Christian Theology", Journal of Religion 48, no. 3 (1968), pp. 235-259.

Amir-Moezzi, Mohammad A. The Spirituality of Shi'i Islam: Beliefs and Practices. London: I.B. Tauris, 2011.

'Aț̣āar, Farīd al-Dīn. Tadhkirat al-awliyā'. Edited by Muhammad Isti‘lāmī. Tehran: Intishārāt-i Zawār, 1392 SH [=2013].

Bashier, Salman. Ibn al- 'Arabī's Barzakh: The Concept of the Limit and the Relationship between God and the World. Albany, NY: State University of New York Press, 2004.

Bayḍ̄āwī, 'Abd Allāh and Maḥmūd Ișfahān̄i. Nature, Man and God in Medieval Islam, in two volumes. Edited and translated by Edwin E. Calverley and James W. Pollock. Leiden: Brill, 2001-2002.

Böwering, Gerhard. "ENSĀN-E KĀMEL”, Encyclopaedia Iranica, online edition.

Böwering, Gerhard and Yousef Casewit (eds). A Qur'an Commentary by Ibn Barrajān of Seville (d. 536/1141): Ị̇̂̄h al-hikma bi-ahkām al-ibra (Wisdom Deciphered, the Unseen Discovered). Leiden: Brill, 2015.

Bukhārī, Muhammad. Le recueil des traditions mahométanes, in four volumes. Edited by Ludolf Krehl. Leiden: Brill, 1862-1908.

Casewit, Yousef. The Mystics of al-Andalus: Ibn Barrajān and Islamic Thought in the Twelfth Century. Cambridge: Cambridge University Press, 2018.

Chittick, William C. "The Chapter Headings of the Fusûs." Journal of the Muhyiddin Ibn 'Arabi Society 2 (1984), pp. 41-94.

Chittick, William C. The Sufi Path of Knowledge: Ibn al-'Arabi's Metaphysics of Imagination. Albany, NY: State University of New York Press, 1989.

Chittick, William C. The Self-Disclosure of God: Principles of Ibn al- 'Arabī's Cosmology. Albany, NY: State University of New York Press, 1998.

Chodkiewicz, Michel. Seal of Saints: Prophethood and Sainthood in the Doctrine of Ibn 'Arabī. Translated by Liadain Sherrard. Cambridge: Islamic Texts Society, 1999. 
Corbin, Henry. Spiritual Body and Celestial Earth: From Mazdean Iran to Shì'ite Iran. Translated by Nancy Pearson. Princeton, NJ: Princeton University Press, 1977.

Ebstein, Michael. Mysticism and Philosophy in al-Andalus: Ibn Masarra, Ibn al-'Arabī and the Ismā 'ìlī Tradition. Leiden: Brill, 2014.

Ebstein, Michael. "Was Ibn Qasī a Șūfî?” Studia Islamica 110 (2015), pp. 196-232.

Farghānī, Sa'd al-Dīn. Muntahá al-madārik fì sharh Tā'iyyat Ibn al-Fāriḍ. Edited by 'Āṣim al-Kayyālī. Beirut: Dār al-Kutub al-'ilmiyyah, 2007.

Gardet, Louis. "Karāma”, Encyclopaedia of Islam, second (new) edition.

Ghazālī, Abū Hầmid. Kitāb-i Kìmīyāayi sa'ādat. Edited by Aḥmad Ārām. Tehran: Chapkhānah-yi Markaz̄i, 1954.

Ghazālī, Abū Hāamid. Mishkāt al-anwār. Edited by Abū al-'Alá 'Afīfì. Cairo: al-Dār alQawmiyyah li-al-țibā'ah wa-al-nashr, 1964.

Ghazālī, Abū Hāmid. Al-Ghazālì on Disciplining the Soul \& On Breaking the Two Desires: Books XXII and XIII of the Revival of the Religious Sciences (Ihyā' 'ulūm al-dīn). Translated by Timothy J. Winter. Cambridge; Islamic Texts Society, 2016.

Goldziher, Ignaz. Introduction to Islamic Theology and Law. Translated by Andras and Ruth Hamori, with introduction and notes by B. Lewis. Princeton, NJ: Princeton University Press, 1981.

Gomaa, 'Ali. Responding From the Tradition: One Hundred Contemporary Fatwas by the Grand Mufti of Egypt. Translated by Nuri Friedlander and Tarek Elgawhary. Louisville, KY: Fons Vitae, 2011.

Graham, William A. Divine Word and Prophetic Word in Early Islam: A Reconsideration of the Sources, With Special Reference to the Divine Saying or Hadith qudsî. The Hague: Mouton, 1977.

Hakīm, Su'ād. Al-Mu 'jam al-șüfi: al-hikmah fì hudūd al-kalimah. Beirut: Dandarah li-alțabā'ah wa-al-nashr, 1981.

Hallāj, al-Husayn. Kitāb al-țawāsīn. Edited and translated by Louis Massignon. Paris: Geuthner, 1913.

Hodgson, Marshall. The Order of the Assassins: The Struggle of the Early Nizârî Ismâillîs against the Islamic World. 's-Gravenhage: Mouton \& Co., 1955.

Hujwīrī, 'Alī. Kashf al-mahjūb: The Oldest Persian Treatise on Súfiism. Translated by Reynold Alleyne Nicholson. Leiden: Brill, 1911.

Ibn 'Adī, Yahyá. Tahdhīb al-akhlāq. Edited by Samīr Khalīl al-Yasū'î. Silsilat Rawā'i' al-turāth al-'arabī al-masīhịi, no date.

Ibn 'Adī. The Reformation of Morals. Edited and translated by Sidney H. Griffith. Provo, UT: Brigham Young University Press, 2002.

Ibn 'Arabī. al-Futūhāat al-Makkiyyah, in four volumes. Egypt: Dār al-Kutub al-'arabiyyah al-kubrá, 1329 AH [=1911].

Ibn 'Arabī. Fuṣūṣ al-ḥikam. Edited by Abū al-'Alá 'Afîfĩ. Beirut: Dār al-Kitāb al-'Arabī, 1946.

Ibn Khaldūn. The Muqaddimah: An Introduction to History, in three volumes. Translated by Franz Rosenthal. London: Routledge \& Kegan Paul, 1958.

Ibn Khaldūn. Muqaddimah, in three volumes. Edited by 'Alī 'Abd al-Wāḥid Wāfì. Cairo: Dār Nahdat Miṣr li-al-nashr, 2014.

Iqbal, Muhammad. "The Doctrine of Absolute Unity as Expounded by Abdul Karim Jilani", Speeches, Writings and Statements of Iqbal, in two volumes. Edited by Ahmad Shirwani. Lahore: Iqbal Academy Pakistan, 2015, pp. 77-97.

Izutsu, Toshihiko. Sufism \& Taoism: A Comparative Study of Key Philosophical Concepts. Berkeley, CA; London: University of California Press, 1984. 
Jāmī, 'Abd al-Raḥmān. Sharḥ al-Jāmī 'alá Fușuṣ al-hikam. Edited by 'Āṣim al-Kayyālī. Beirut: Dār al-Kutub al-'ilmiyyah, 2004.

Jīlī, 'Abd al-Karīm. Al-Insān al-kāmil fì ma'rifat al-awākhir wa-al-awā'il. Edited by Șalāḥ ibn Muḥammad 'Uwayḍah. Beirut: Dār al-Kutub al-'ilmiyyah, 1997.

Jīlī, 'Abd al-Karīm. Sharh mushkilāt al-Futūhạat al-Makkiyyah. Edited by Youssef Ziedan. Cairo: Dār al-Amīn, 1999.

Jīlī, 'Abd al-Karīm. Marātib al-wujūd wa-ḥaqīqat kull mawjūd. (No editor listed.) Cairo: Maktabat al-Qāhirah, 1999.

Johns, Anthony H. "Fall of Man", Encyclopaedia of the Qur'ān, online edition.

Kellner, Menachem. Maimonides on Human Perfection. Brown Judaic Studies 202. Atlanta, GA: Scholars Press, 1990.

Khalidi, Tarif. The Muslim Jesus: Sayings and Stories in Islamic Literature. Cambridge, MA; London: Harvard University Press, 2001.

Kister, Meir J. "Ādam: A Study of Some Legends in Tafsīr and Hadīt Literature", Israel Oriental Studies 13 (1993), pp. 113-174.

Köhler, Ludwig, Walter Baumgartner, M.E.J. Richardson, and Johann J. Stamm. The Hebrew and Aramaic Lexicon of the Old Testament, in five volumes. Leiden: Brill, 1994-2000.

Krinis, Ehud. "The Philosophical and Theosophical Interpretations of the MicrocosmMacrocosm Analogy in Ikhwān aș-Safā' and Jewish Medieval Writings", L'Ésoterisme Shi ‘ite: ses racines et ses prolongements. Edited by Mohammad Ali Amir-Moezzi, Maria De Cillis, Daniel De Smet, and Orhan Mir-Kasimov. Turnhout: Brepols, 2016, pp. 395-409.

Madelung, Wilferd. “'Ișmah”, Encyclopaedia of Islam, second (new) edition.

Mahdi, Muhsin. Ibn Khaldūn's Philosophy of History: A Study in the Philosophic Foundation of the Science of Culture. London: G. Allen \& Unwin, 1957.

Maimonides, Moses. The Guide of the Perplexed. Translated and introduced by Shlomo Pines, with an introductory essay by Leo Strauss. Chicago, IL: University of Chicago Press, 1963.

Melchert, Christopher. "God Created Adam in His Image”, Journal of Qur'anic Studies 13, no. 1 (2011), pp. 113-124.

Melchert, Christopher. "Origins and Early Sufism", The Cambridge Companion to Sufism. Edited by Lloyd Ridgeon. Cambridge: Cambridge University Press, 2015, pp. 3-23.

Muslim, Abū al-Ḥusayn. Șah̄h Muslim, 18 volumes in 9. Edited by Muhammad 'Abd al-Bāqī. Beirut: Dār al-Kutub al-'ilmiyyah, 1995.

Nasr, Seyyed H. An Introduction to Islamic Cosmological Doctrines: Conceptions of Nature and Methods Used for Its Study by the Ikhwān al-Safā', al-Bīrūnī and Ibn Sinnā. London: Thames \& Hudson, 1978.

Nettler, Ronald L. Sufi Metaphysics and Qur'ānic Prophets: Ibn 'Arabī's Thought and Method in the Fuṣuṣ al-hịam. Cambridge: Islamic Texts Society, 2003.

Nicholson, Reynold A. Studies in Islamic Mysticism. Richmond, UK: Curzon Press, 1921.

Nūrbakhsh, Javād. Farhang-i Nürbakhsh (ișțilāhāt-i tașawwuf), in eight volumes. Tehran: Chāpkhāneh-yi Marvī, 1371 SH [= 1992/1993].

Padwick, Constance. Muslim Devotions. Oxford: Oneworld, 1996.

Qāshānī, 'Abd al-Razzāq. Sharh 'alá Fuṣ̂ṣ al-ḥikam. Egypt: al-Maṭba'ah al-Yamaniyyah, (no date).

Qāshānī, 'Abd al-Razzāq. Mu 'jam iștilāḥāt al-ṣūfiyyah. Edited by 'Abd al-'Āl Shāhīn. Cairo: Dār al-Manār, 1992. 


\section{The Perfect Human}

Qayșarī, Dāwūd. Sharḥ-i muqaddamah- 'i Qayșarī bar Fușūṣ al-hikam-i Muhyī al-Dīn 'Arabī. Edited by Jalāl al-Dīn Āshtiyānī. Mashhad: Kitābfurūshī-yi bāstān, 1350 SH [=1966].

Qūnawī, Șadr al-Dīn. I'jāzz al-bayān fì tafsīr umm al-Qur'ān. Edited by Jalāl al-Dīn Āshtiyānī. Qom: Mu'assasah-yi Būstān-i Kitāb-i Qom, 1380 SH/1423 AH [=2002].

Qūnawī, Șadr al-Dīn. Miftāh ghayb al-jam' wa-al-wujūd. Edited by 'Āṣim al-Kayyāl̄̄. Beirut: Dār al-Kutub al-'ilmiyyah, 2010.

Qushayrī, 'Abd al-Karīm. Al-Risālah al-Qushayriyyah. Edited by Khalīl Manșūr. Beirut: Dār al-Kutub al-'ilmiyyah, 2001.

Radtke, Bernd and John O'Kane. The Concept of Sainthood in Early Islamic Mysticism: Two Works by Al-Hakim Al-Tirmidhì. Abingdon, UK: Routledge, 1996.

Rahman, Fazlur. Prophecy in Islam: Philosophy and Orthodox. London: George Allen \& Unwin Ltd, 1958.

Sarrāj, Abū Nașr. Kitāb al-Luma 'fì al-tașawwuf. Edited by Reynold Alleyne Nicholson. Leiden: Brill, 1914.

Schimmel, Annemarie. Mystical Dimensions of Islam. Chapel Hill, NC: University of North Carolina Press, 1975.

Schmidkte, Sabine. The Theology of al-'Allāma al-Hillī (d. 726/1325). Berlin: Klaus Schwarz Verlag, 1991.

Tahānawī, Muḥammad. Kashshāf iștilāhāāt al-funūn. Edited by Luṭ̂ī 'Abd al-Badī', 'Abd al-Mun'im Husayn and Amīn Khūlī. Cairo: al-Mu'assasah al-Mișrīyah al-'āmmah li-lta' līf wa-al-tarjamah wa-al-țibā ah wa-al-nashr, 1963.

Takeshita, Masataka. Ibn 'Arabi's Theory of the Perfect Man and its Place in the History of Islamic Thought. Doctoral thesis, University of Chicago, IL, 1987.

Taleb, Nassim N. Antifragile: How to Live in a World We Don't Understand. London: Allen Lane, 2012.

Todd, Richard. The Sufi Doctrine of Man: Sadr al-Dīn al-Qūnawì's Metaphysical Anthropology. Leiden: Brill, 2014.

van Ess, Josef. Theology and Society in the Second and Third Centuries of the Hijra: A History of Religious Thought in Early Islam, in four volumes. Translated by John O'Kane and Gwendolin Goldbloom. Leiden; Boston, MA: Brill, 2017-2019.

Walzer, Richard. “Al-Fārābī's Theory of Prophecy and Divination”, Journal of Hellenic Studies 77, no. 1 (1957), pp. 142-148.

Zarkashī, Badr al-Dīn. Al-Burhān fì 'ulūm al-Qur'ān, in four volumes. Edited by Muḥammad Abū Faụl Ibrāhīm. Cairo: Dār al-Turāth, 1984. 
We can therefore summarise al-Jîlî's position on the identity of the Pole in the following way: Muhammad, both as the Muhammadan Reality and as Muhammad the Messenger of God, is the one true Pole, from the beginning until the end of time. However, the station of Pole is also attained by at least some of the other prophets and the pre- and post-Muhammadan 'Friends of God'. These Friends of God, however, seem to be Poles only in a lesser sense, that is, as reflections or embodiments of Muhammad, the one true Pole. This leads us directly on to the idea of the Muhammadan Reality, to which we shall now turn our attention.

\section{Notes}

1 See Hujwīì̄, Kashf al-mahjūb, 438, s.v. "Quțb”; Ziedan, al-Fikr, 160-163; Ebstein, Mysticism and Philosophy, 130; 'A. al-J̄̄lān̄ī, Dīwān Abd al-Qādir al-Jīlānī, ed. Y. Ziedan (Beirut: Dār al-J̄̄l, n.d.), s.v. "al-quțb".

2 See Jamil, "Caliph and Qutb"; N. Jamil, Ethics and Poetry in Sixth Century Arabia (Trumpington, UK: E.J.W. Gibb Memorial Trust, 2018), 332.

3 See al-Hakīm, al-Mu 'jam, 909.

4 For Ibn 'Arabī's conception of the 'Unique Ones' and 'Ones Brought Near', see Takeshita, Ibn 'Arabī's Theory, 128-131; Chodkiewicz, Seal, 111-115.

5 See Chodkiewicz, Seal, 58, 91-99.

6 Ibn 'Arabī, Futūḥ̄t, 2:573, quoted in al-Hakīm, al-Mu 'jam, 912. See also Ibn 'Arabī, Futūḥ̄t, 3:136-137; al-Hakīm, al-Mu 'jam, 913.

7 Ibn 'Arabī, Kitāb Manzil al-quṭb wa-maqāmihi wa-ḥālihi, 2, in Rasā'il Ibn 'Arabī, vol. 2 (Hyderabad: Maṭba'at Jam'iyyat Dā'irat al-ma'ārif al-'uthmaniyyah, 1367 AH [=1948]), no page numbers.

8 See al-Hakīm, al-Mu'jam, 914, note 1, where she notes that Ibn 'Arabī does not explicitly identify the Pole with the Perfect Human.

9 Ibn 'Arabī, Fușūș, 49-50.

10 See Nettler, Sufi Metaphysics, 154-175; Izutsu, Sufism \& Taoism, 116-140.

11 Ibn 'Arabī, Futūhāt, 2:5; al-Ḥakīm, al-Mu'jam, 912. For the full passage in which this statement occurs, see Chodkiewicz, Seal, 93.

12 Al-Qāshān̄̄, Mu 'jam, 162. See also Tahānawī, Kashshāf, 1327-1330.

13 Ibn 'Arabī, Futūhāt, 2:5; al-Hakīm, al-Mu 'jam, 912.

14 Ibn 'Arabī, Fușūs, 50.

15 Quoted in Nūrbakhsh, Farhang, 6:5.

16 Hujwīrī, Kashf al-mahjūb, 214; Nūrbakhsh, Farhang, 6:6.

17 Ibn 'Arabī, Futūhàt, 2:6; cf. Chodkiewicz, Seal, 94-95.

18 Ibn 'Arabī, Futūhāt, 2:555; al-Hakīm, al-Mu 'jam, 912.

19 Similarly, the thirteenth century Persian Sufi thinker 'Azīz-i Nasafì, who drew upon Ibn 'Arabī among others in his conception of the Perfect Human, stressed the point that there is only one Perfect Human or Pole in the world at any one time. See L. Ridgeon, 'Azìz Nasafì (Richmond, UK: Curzon, 1998), 176-177.

20 Ibn 'Arabī, Futūhāt, 2:6. See also Chodkiewicz, Seal, 94.

21 For an exegesis of this passage, see S. Hirtenstein, "The Healer of Wounds: Interpreting Human Existence in the Light of Alchemy and Ascension", Muhyiddin Ibn "Arabi Society Oxford Symposium 2018, 19 May 2018, www.ibnarabisociety.org/ podcasts/archives/1807/hirtenstein.mp3.

22 Ibn 'Arabī, Futūḥ̄àt, 1:151; al-Sha'rānī, al-Kibrīt al-aḥmar fì bayān 'ulūm al-shaykh al-akbar, ed. A 'Umar (Beirut: Dār al-Kutub al-'ilmiyyah, 1998), 12; Chodkiewicz, Seal, 94; G. Lipton, Rethinking Ibn 'Arabi (New York: Oxford University Press, 2018), 78-79. 
23 Al-Hakīm, al-Mu'jam, 915.

24 Ibn 'Arabī, Futūḥāt, 2:5; al-Ḥakīm, al-Mu 'jam, 911.

25 See Ibn 'Arabī, Futūhāt, 2:7; Chodkiewicz, Seal, 94. See also Ebstein, Mysticism and Philosophy, 135; Lipton, Rethinking, 78.

26 The 'Pegs' (awtād) are the highest members of the cosmic hierarchy, and are four in number. See al-Hakīm, al-Mu'jam, 517. Ibn 'Arabī indicates here that Jesus and Elijah are the 'two Imams' and Khiḍr the fourth 'Peg'. See Ibn 'Arabī, Futūhāt, 2:7; Chodkiewicz, Seal, 94.

27 Ibn 'Arabī, Futūhāt, 2:7.

28 Ibid., 3:182.

29 See ibid., 2:8; Chodkiewicz, Seal, 95.

30 See G. Vermes, The Resurrection (London: Penguin, 2008), 32-34; J. Reeves and A. Reed, Enoch from Antiquity to the Middle Ages, vol. 1: Sources from Judaism, Christianity and Islam (Oxford: Oxford University Press, 2018), 1-2, 210-253.

31 See e.g. al-Tha'labī, 'Arā'is al-majālis fi qișaș al-anbiyà', or, "Lives of the prophets", tr. W.M. Brinner (Leiden: Brill, 2002), 83-85; Reeves and Reed, Enoch, 216-217, 225-228. The motif is cited by the Persian Sufi 'Azīz-i Nasafì in his discussion of the 'spiritual death' of the Friends of God. See Ridgeon, 'Azīz Nasafì, 181. Similarly, Rūzbihān Baqlī, another important Persian Sufi thinker, lists Idrīs among the four special individuals (the others being Khị̂r, Elijah, and Jesus) who were "carried off alive from death". See ibid., 202, note 68.

32 Jamil, Ethics and Poetry, 332-334.

33 Ibn 'Arabī, Fușūṣ, 75.

34 Ibid.

35 Note that whereas in the Futūhăt Ibn 'Arabī appears to draw a distinction between Idrīs and Elijah/Ilyās, in the Fuṣuṣs he explicitly identifies them. See ibid., 181: "Ilyās is Idrīs, who was a prophet before Noah."

36 Ibid., 181. Cf. 2 Kings 11, where a horse-drawn chariot of fire appears to the prophet Elijah, who is carried up to heaven in a whirlwind.

37 For the connection between Idrīs and Hermes and their occult associations, see F.E. Peters, "Hermes and Harran: The Roots of Arabic-Islamic Occultism", Magic and Divination in Early Islam, ed. E. Savage-Smith (Aldershot: Ashgate, 2004), 55-86, esp. 59-60.

38 See R. Nettler, “Ibn 'Arabi's Gloss on the Prophet Yunus: Sufism and the Continuity of a Common Religious Culture", The Religion of the Other: Essays in Honour of Mohamed Talbi, ed. M. Ben-Madani (London: Maghreb Publications, 2013), 53-60.

39 Ibn 'Arabī, Futūhāat, 1:151, quoted in Chodkiewicz, Seal, 94; Lipton, Rethinking, 78-79. See also Ibn 'Arabī, Kitāb Manzil al-quṭb, in Rasā'il, 2:6: "The most perfect (akmal) of the Poles is the Muhammadan."

40 Al-Qayșarī, Sharh̆-i muqaddamah, 490.

41 See ibid., 491.

42 Ibid., 457.

43 Ibn Khaldūn, Muqaddimah, 3:997. For an alternative translation (and notes on the Sufi thinkers referred to in this passage), see Ibn Khaldūn, The Muqaddimah, 92-93.

44 See e.g. Afífi, Mystical Philosophy, 75, 90; H. Corbin, Alone with the Alone: Creative Imagination in the Süfism of Ibn 'Arabī, tr. R. Manheim (Princeton, NJ: Princeton University Press, 1998), 45; Takeshita, Ibn 'Arabī's Theory, 168-169; Ebstein, Mysticism and Philosophy, 155, note 98.

45 The key conceptual and semantic building blocks of both the Sufi metaphysical idea of walāyah or Perfect Human and the Shī'i doctrine of the Imamate are already discernible in the Umayyad conception of the caliphate. See Crone and Hinds, God's Caliph, 24-42. Jamil, "Caliph and Qutb", has shown how the key elements of this conception have their origins in pre-Islamic Arabian ideas.

46 M. Hodgson, "How Did the Early Shî‘a Become Sectarian?" Journal of the American Oriental Society 75, no. 1 (1955), 1-13, 2. A similar argument been made by Valerie 
Hoffman, who proposes that the centrality of the Prophet and his family within modern Egyptian Sufism (perhaps under the influence of Ibn 'Arabian ideas) is possible evidence in support of Hodgson's statement. See V. Hoffman, "Devotion to the Prophet and His Family in Egyptian Sufism", International Journal of Middle East Studies 24, no. 4 (1992), 615-637, 615.

47 Al-J̄̄lì , al-Insān, 210.

48 Ibid.

49 It is clear that al-Jīli did identify the Pole with the Muhammadan Reality. For instance, he tells us in chapter 51 that "the angel called the spirit" (al-malak almusammá bi-al-rūh) is both synonymous with the Muhammadan Reality and with "the Pole of the orbits of created beings" (quṭb aflāk al-makhlūqāt). Ziedan, al-Fikr, 31; Knysh, Ibn 'Arabi, 251.

50 See al-J̄ilì, al-Insān, 204-205. See also Ziedan, al-Fikr, 31; Knysh, Ibn 'Arabi, 251.

51 Al-J̄ilì, al-Insān, 188-189.

52 Ibid., 260; A. Tafaz̧zolī and B. Hourcade, Encyclopaedia Iranica (online edition), s.v. "Damavand".

53 See Rosenthal, "Ibn 'Arabī”, 15.

54 See Ibn 'Arabī, Futūhāt, 1:151, where, immediately preceding his aforementioned account of his vision of 25 mysterious figures, he refers to "the perfected Poles (aqtāab...al-mukammalīn) in other communities than ours, who preceded us in time".

55 Al-Jīlī, al-Insān, 128. See also ibid., 126:

Nevertheless, each one of the unique ones $(a f r \bar{a} d)$ and the poles (aqtāab) [other than David and Solomon] possesses mastery (al-tașarruf) over the whole of the existential kingdom (al-mamlakah al-wujüdiyyah), and each of them knows what trembles (ikhtalaja) day and night, besides the languages of the birds.

56 Ibid., 236.

57 Takeshita, Ibn 'Arabì's Theory, 114.

58 See al-J̄ilì̄, al-Insān, 194.

\section{Bibliography}

'Afĩfì, Abū al-'Alá. The Mystical Philosophy of Muhyid Dín Ibnul 'Arabí. Cambridge: University Press, 1939.

Chodkiewicz, Michel. Seal of Saints: Prophethood and Sainthood in the Doctrine of Ibn 'Arabī. Translated by Liadain Sherrard. Cambridge: Islamic Texts Society, 1999.

Corbin, Henry. Alone with the Alone: Creative Imagination in the Süfism of Ibn 'Arabì. Translated by Ralph Manheim. Princeton, NJ: Princeton University Press, 1998.

Crone, Patricia and Martin Hinds. God's Caliph: Religious Authority in the First Centuries of Islam. Cambridge: Cambridge University Press, 2003.

Ebstein, Michael. Mysticism and Philosophy in al-Andalus: Ibn Masarra, Ibn al-'Arabī and the Ismā ‘̂̀lì Tradition. Leiden: Brill, 2014.

Ḥakīm, Su'ād. Al-Mu 'jam al-șüfi: al-hikmah fì hudūd al-kalimah. Beirut: Dandarah li-alțabā'ah wa-al-nashr, 1981.

Hirtenstein, Stephen. "The Healer of Wounds: Interpreting Human Existence in the Light of Alchemy and Ascension". Lecture delivered at the Muhyiddin Ibn 'Arabi Society Oxford Symposium 2018, 19 May 2018, www.ibnarabisociety.org/podcasts/ archives/1807/hirtenstein.mp3.

Hodgson, Marshall. "How Did the Early Shî‘a Become Sectarian?" Journal of the American Oriental Society 75, no. 1 (1955), pp. 1-13. 
Hoffman, Valerie. "Devotion to the Prophet and His Family in Egyptian Sufism", International Journal of Middle East Studies 24, no. 4 (1992), pp. 615-637.

Hujwīrī, 'Alī. Kashf al-mahjūb: The Oldest Persian Treatise on Șúfism. Translated by Reynold Alleyne Nicholson. Leiden: Brill, 1911.

Ibn 'Arabī. al-Futūhāt al-Makkiyyah, in four volumes. Egypt: Dār al-Kutub al-'arabiyyah al-kubrá, 1329 AH [=1911].

Ibn 'Arabī. Fuṣūṣ al-ḥikam. Edited by Abū al-'Alá 'Afîfī. Beirut: Dār al-Kitāb al-'Arabī, 1946.

Ibn 'Arabī. Rasā'il Ibn 'Arabī, in two volumes. Hyderabad: Maṭba'at Jam'iyyat Dā'irat al-ma'ārif al-'uthmaniyyah, 1948.

Ibn Khaldūn. The Muqaddimah: An Introduction to History, in three volumes. Translated by Franz Rosenthal. London: Routledge \& Kegan Paul, 1958.

Ibn Khaldūn. Muqaddimah, in three volumes. Edited by 'Alī 'Abd al-Wāḥid Wāfì. Cairo: Dār Nahdat Miṣr li-al-nashr, 2014.

Izutsu, Toshihiko. Sufism \& Taoism: A Comparative Study of Key Philosophical Concepts. Berkeley, CA; London: University of California Press, 1984.

Jamil, Nadia. "Caliph and Qutb. Poetry as a Source for Interpreting the Transformation of the Byzantine Cross on Steps on Umayyad Coinage", Bayt al-Maqdis, Jerusalem and Early Islam: Oxford Studies in Islamic Art 9, Part Two. Edited by Jeremy Johns. Oxford: Oxford University Press, 1999, pp. 11-57.

Jamil, Nadia. Ethics and Poetry in Sixth Century Arabia. Trumpington, UK: E.J.W. Gibb Memorial Trust, 2018.

Jīlān̄̄, 'Abd al-Qādir. Dīwān Abd al-Qādir al-Jîlānī. Edited by Youssef Ziedan. Beirut: Dār al-Jīl, no date.

Jīlī, 'Abd al-Karīm. Al-Insān al-kāmil fì ma'rifat al-awākhir wa-al-awā'il. Edited by Șalāḥ ibn Muḥammad 'Uwayḍah. Beirut: Dār al-Kutub al-'ilmiyyah, 1997.

Knysh, Alexander. Ibn 'Arabi in the Later Islamic Tradition: The Making of a Polemical Image in Medieval Islam. Albany, NY: State University of New York Press, 1999.

Lipton, Gregory. Rethinking Ibn 'Arabi. New York: Oxford University Press, 2018.

Nettler, Ronald L. Sufi Metaphysics and Qur'ānic Prophets: Ibn 'Arabī's Thought and Method in the Fușuṣ al-hikam. Cambridge: Islamic Texts Society, 2003.

Nettler, Ronald L. "Ibn 'Arabi's Gloss on the Prophet Yunus: Sufism and the Continuity of a Common Religious Culture", The Religion of the Other: Essays in Honour of Mohamed Talbi. Edited by Mohamed Ben-Madani. London: Maghreb Publications, 2013, ch. 7.

Nūrbakhsh, Javād. Farhang-i Nürbakhsh (iștilāhāat-i tașawwuf), in eight volumes. Tehran: Chāpkhāneh-yi Marvī, 1371 SH [= 1992/1993].

Peters, F.E. "Hermes and Harran: The Roots of Arabic-Islamic Occultism", Magic and Divination in Early Islam. Edited by Emilie Savage-Smith. Aldershot: Ashgate, 2004, pp. 55-86.

Qāshānī, 'Abd al-Razzāq. Mu 'jam iṣtiliạhāt al-ṣūfiyyah. Edited by 'Abd al-'Āl Shāhīn. Cairo: Dār al-Manār, 1992.

Qayșarī, Dāwūd. Sharh-i muqaddamah- 'i Qayșarī bar Fușūṣ al-hikam-i Muhyī al-Dīn 'Arabī. Edited by Jalāl al-Dīn Āshtiyānī. Mashhad: Kitābfurūshī-yi bāstān, 1350 SH [=1966].

Reeves, John and Annette Y. Reed. Enoch from Antiquity to the Middle Ages, vol. 1: Sources from Judaism, Christianity and Islam. Oxford: Oxford University Press, 2018.

Ridgeon, Lloyd. 'Azīz Nasafí. Richmond, UK: Curzon, 1998.

Rosenthal, Franz. 'Ibn 'Arabī between 'Philosophy' and 'Mysticism': 'Sūfism and Philosophy are Neighbors and Visit Each Other': fa-inna at-tașawwuf wa-t-tafalsuf yatajāwarāni wa-yatazāwarāni”, Oriens 31 (1988), pp. 1-35. 


\section{The Perfect Human}

Sha'rān̄̄, 'Abd al-Wahhāb. Al-Kibrīt al-ahmmar fì bayān 'ulūm al-shaykh al-akbar. Edited by 'Abd Allāh Maḥmūd Muḥammad 'Umar. Beirut: Dār al-Kutub al-'ilmiyyah, 1998.

Tafaz̧zolī, Ahmad and Bernard Hourcade. "Damavand", Encyclopaedia Iranica, online edition.

Tahānawī, Muḥammad. Kashshāf iștilāhạāt al-funūn. Edited by Luṭ̂ī 'Abd al-Badī', 'Abd al-Mun'im Husayn, and Amīn Khūlī. Cairo: al-Mu’assasah al-Mișrīyah al-'āmmah li-lta' līf wa-al-tarjamah wa-al-țibā'ah wa-al-nashr, 1963.

Takeshita, Masataka. Ibn 'Arabì's Theory of the Perfect Man and its Place in the History of Islamic Thought. Doctoral thesis, University of Chicago, IL, 1987.

Tha'labī, Ahmmad. 'Arā'is al-majālis fì qișaș al-anbiyā', or, "Lives of the prophets". Translated and annotated by William M. Brinner. Leiden: Brill, 2002.

Vermes, Geza. The Resurrection. London: Penguin, 2008.

Ziedan, Youssef. Al-Fikr al-șūfì 'ind 'Abd al-Karìm al-Jìlī. Cairo: Dār al-Amīn, 1998. 


\section{Notes}

1 Hourani, History of the Arab Peoples, 177.

2 See Rubin, "Pre-Existence and Light".

3 For the synonymy of these three terms in Ibn 'Arabī's thought, see al-Hakīm, alMu jam, 347-349.

4 See Karamustafa, Sufism, 42-47. These mystics may themselves have drawn upon Shi'i ideas. See ibid., 52, note 18; M.A. Amir-Moezzi, The Divine Guide in Early Shi ism: The Sources of Esotericism in Islam, tr. D. Streight (Albany, NY: State University of New York Press, 1994), 29-60.

5 See Takeshita, Ibn 'Arabì's Theory, 164-169; Chodkiewicz, Seal, 27-32, 53-54, 65, 116-118; B. Abrahamov, Ibn al-'Arabī and the Sufis (Oxford: Anqa Publishing, 2014), 53-62, 85-90. Note also the appearance of this idea in the tafsir attributed to the sixth Shī‘̄i Imām Ja‘far al-Ṣādiq (d. 765), quoted in Chodkiewicz, Seal, 65.

6 Quoted in Karamustafa, Sufism, 42.

7 See ibid.

8 See 'Afífi, Mystical Philosophy, 75.

9 See e.g. Ibn 'Arabī, Fușūṣ, 214; Ibn 'Arabī, Futūḥāt, 3:141-142; Afìfî, Mystical Philosophy, 73; Izutsu, Sufism \& Taoism, 236; Chodkiewicz, Seal, 50.

10 See e.g. al-Farghān̄̄, Muntahá al-madārik, 29; Izutsu, Sufism \& Taoism, 237; Chodkiewicz, Seal, 63. According to Jonathan Brown, the authenticity of this hadith was rejected by medieval hadith collectors, "even those ... known for their laxity. Belief in [their] truth persisted, however, especially among Sufi scholars", Brown, Misquoting, 228.

11 See Chodkiewicz, Seal, 68, note 28.

12 See 'Afĩfī, Mystical Philosophy, 68; Izutsu, Sufism \& Taoism, 237-238; Ebstein, Mysticism and Philosophy, 155, 206. Ebstein highlights the affinity of this notion with the Ismaili Neoplatonic conception of the First Intellect, for which see also M. Hodgson, The Secret Order of Assassins: The Struggle of the Early Nizârî Ismâ îlîs Against the Islamic World (The Hague: Mouton \& Co., 1955), 16-17.

13 Ibn 'Arabī, Futūhāt, 1:119; Chodkiewicz, Seal, 94; al-Hakīm, al-Mu'jam, 348-349.

14 See 'Afifi', Mystical Philosophy, 72-74. The idea that the prophets (and Friends of God) draw upon the light of Muhammad is also found in Khal al-na 'layn of the Algarvian mystic and rebel leader Ibn Qasī, a work on which Ibn 'Arabī wrote a commentary. See Ebstein, "Was Ibn Qasī a Șūfî?" 219.

15 Ibn 'Arabī, Fușūṣ, 63-64. See also ibid., 62:

This knowledge ('ilm) is only for the Seal of Messengers (khätim al-rusul) and the Seal of the Friends of God (khätim al-awliy $\bar{a}$ '), and none of the prophets and messengers knows it, except from the lamp (mishkät) of the Messenger who is the Seal.

Ibn 'Arabī, Kitāb Manzil al-quṭb, in Rasā'il, 2:6: "Every [Pole] is in the lamp (mishkāt) of Muhammad - Peace be upon him - who is that which encompasses everything (al-amr al-jāmi “ li-al-kull)."

16 Chittick, "Chapter Headings", 86.

17 Al-Farghānī, Muntahá al-madārik, 29.

18 Al-Qāshān̄i, Sharh, 266. For an alternative translation, see Izutsu, Sufism \& Taoism, 237. See similarly al-Qayșarī, Sharh-i muqaddamah, 457: "the Muhammadan Reality is the form of the all-comprehensive divine name (șürat al-ism al-jāmi 'al-ilāhù) and its lord, and from it [occurs] [His] emanation (fayḍ) and extension (al-istimdād) over all the other names"; Jāmī, Sharh, 57.

19 For this verse from Ibn al-Fāriḍ's Tã'iyyah, see Chodkiewicz, Seal, 67.

20 'Irāqī, Lama 'àt, in Kulliyāt-i Fakhruddīn-i 'Irāqū, ed. S. Nafîsī (Tehran: Kitābkhāna-yi Sanā' 1 , 1338 SH [= 1956/1957]), 375.

21 Al-Farghānī, Muntahá al-madārik, 39-40. 


\section{The Perfect Human}

22 Al-Qayṣarī, Sharḥ-i muqaddamah, 490.

23 See Nicholson, Studies, 87, 104ff.; A. Jeffrey, "Ibn 'Arabī’s Shajarat al-kawn", Studia Islamica 10 (1959), 43-77, 11 (1960), 113-160 (note that the attribution of this text to Ibn 'Arabī appears to be mistaken); 'Afîfī, Mystical Philosophy, 66-101; Izutsu, Sufism \& Taoism, 236-238; Chodkiewicz, Seal, 64. There is also a parallel with the presentation of Wisdom in the Book of Proverbs: "The Lord brought me forth as the first of his works, before his deeds of old; I was formed long ages ago, at the very beginning, when the world came to be" (Prov. 8:22-31) Indeed, "Philo had interpreted the pre-existence Wisdom spoken of in apocalyptic and rabbinic sources as the equivalent of the Logos", Altmann, "Homo Imago Dei", 245.

24 C. Lévy, Stanford Encyclopedia of Philosophy, s.v. "Philo of Alexandria".

25 See also 1 Cor. 8:6, where Paul writes, "and there is but one Lord, Jesus Christ, through whom all things came and through whom we live". Cf. Altmann, "Homo Imago Dei", 245-246. According to Martin Goodman, Paul "casts Christ's preexistence, before incarnation as Jesus, in a role similar to Wisdom in earlier Jewish texts or the Logos in Philo". M. Goodman, A History of Judaism (London: Allen Lane, 2018), 193.

26 Lévy, "Philo of Alexandria". See also Jeffrey, "Ibn "Arabī's Shajarat al-kawn", 46. Cf. Goodman, History of Judaism, 175: "Sometimes Philo identified the Logos with the mind of God. At other times, the Logos was reckoned 'midway between man and God'."

27 This title can be explained by the fact that the Qur'anic exegetes gloss "the Trustworthy Spirit" (al-rüh al-aminn) of the Qur'an (see Q 26:193) with the Angel Gabriel.

28 Al-Jīlī, al-Insān, 152-153.

29 For the pre-Islamic antecedents of this image and its association with the qutb, see Jamil, "Caliph and Qutb", 18-19, 30; Jamil, Ethics and Poetry, 332. For Ibn 'Arabī's use of the term, see Ibn 'Arabī, Fușūṣ, 75, cited in Ebstein, Mysticism and Philosophy, 135.

30 Ebstein, Mysticism and Philosophy, 57-60.

31 See also al-Jîlī, al-Insān, 166: "It is the First Intellect connected to Muhammad from which God created Gabriel - Peace be upon him - in pre-eternity. So Muhammad was the father of Gabriel and the origin of the whole world."

32 See also ibid., 146:

The Pen is the First Intellect, and they are both faces of the Muhammadan Tablet (al-lawh al-Muhammadī). He - peace and blessings be upon him - said, "The first thing that God created was the spirit of your prophet, O Jäbir." So the Highest Pen, the First Intellect, and the Muhammadan Spirit (al-rūh al-Muhammadī) are an expression of a single essence (jawhar fard), which, in connection to creation is called the Highest Pen, in connection to creation's request [for existence] is called the First Intellect, and in its being added to the Perfect Human is called a Muhammadan Spirit.

The hadith that al-Jîli cites here - which had earlier been cited in this context by Ibn 'Arabī and his interpreters - was widely believed to be a forgery by hadith scholars. See Gomaa, Responding, 147.

33 See Afĩfì, Mystical Philosophy, 66-67; al-Hakīm, al-Mu'jam, 813, for full lists of names that Ibn 'Arabī uses as synonyms for the Muhammadan Reality. For al-Qūnaw'̄'s and al-Farghān̄̄'s use of these terms as synonyms, see Todd, Sufi Doctrine, 65, 67.

34 See Afifi, Mystical Philosophy, 75, note 4, 177; Chodkiewicz, Seal, 69, note 20; Böwering and Casewit, A Qur'an Commentary by Ibn Barrajān, 42-43.

35 Ibn 'Arabī, Futūhăat, 2:391; Ebstein, Mysticism and Philosophy, 55. See also Ibn 'Arabī, Futūhạt, 2:396; al-Ḥakīm, al-Mu 'jam, 162.

36 See Ibn 'Arabī, Fușūss, 48. 
37 Thus Tahānawī's entrance on "al-dhāt", for instance, is almost entirely devoted to the divine essence. See Tahānawī, Kashshāf, 816-818.

38 See al-Jīlì, al-Insān, 206. For the distinction between al-wujūd al-muțlaq and al-wujūd al-muqayyad/al-mumkin in the Sufi metaphysics of Ibn 'Arabī and his interpreters, see al-Hakīm, al-Mu'jam, 1133.

39 See Tahānawī, Kashshāf, 816-817, for the dominant Ash'arī view that "His essence May He be exalted - is distinguished from all other essences."

40 See ibid., 685.

41 See e.g. al-Jīlì al-Insān, 173, where al-Jīli identifies Muhammad with the Mother of the Book (umm al-kitäb), which, according to his Sufi metaphysical conception of the scriptures, is "an expression of the quiddity of the true nature of the essence" (māhiyat kunh al-dhāt), i.e. of the hidden divine essence itself; Lo Polito, 'Abd al-Karim, 159/208, for the passage in al-Kahf wa-al-raqim where al-Jīli recounts his vision that the Prophet was both qualified by the attributes of the divine self and was "the unseen essence itself" ( 'ayn al-dhät al-ghä'ib).

42 See, for instance, his definition of al-'aql al-awwal in chapter 53:

The First Intellect [the edition I am using mistakenly reads 'al-fi ' $\mathrm{al}$-awwal' here] is a light of divine knowledge (nür 'ilm ilahhi) which appeared in the first of His created, entifying descents (awwal tanazzulätihi al-ta yiniyyah al-khalqiyyah), or if you wish you could say that it is the first specification of the divine comprehensiveness (awwal tafșill al-ijmāl al-ilāhì).

(Al-Jīlī, al-Insān, 164)

See also al-Jīlī, al-Kamālāt, 325: "And He called him [namely, Muhammad] the First Intellect, because he was the first thing that was 'intellected'."

43 Al-Jīlīi, al-Insān, 210-211.

44 'Aț̣ār, Tadhkirat al-awliyā', 536. For the whole entry on al-Shiblī, see ibid., 536-557.

45 Ibid., 647.

46 See al-Jīilì, al-Insān, 126.

47 Al-Zabīì̄, Tabaqāt, 101.

48 These individuals, it should be noted, are 'viceregents' in the sense of being what al-Jîli calls in the aforementioned passage from the chapter on the Psalms "the greater viceregents" (al-khulafä' al-kubrá), that is, viceregents not in the political sense of 'caliphs', but rather the elite 'Friends of God' - i.e. the Poles and the 'Unique Ones'. See al-Jīlì, al-Insān, 126.

49 See also ibid., 265, where al-Jīli both refers to the Perfect Ones as "viceregents of Muhammad" (khulafä' Muhammad) and to how they "deputise for Muhammad" (nāba 'an Muhammad).

50 Ibn 'Arabī, it should be noted, encourages the reader of the Futūhāt to try to "see the Real in the Muhammadan form (al-șürah al-muhammadiyyah), through the Muhammadan vision (al-ru'yah al-muhammadiyyah), rather than [to] see Him in your form", Ibn 'Arabī, Futūḥāt, 4:433; Hakīm, al-Mu 'jam, 500.

51 Al-Jīlì, al-Insān, 157. See also ibid., 260, where, having alluded to the esoteric "mysteries" (asrār), "wisdom" (hikmah), and "allusions" (ishārāt) contained in Jewish rituals, he declares,

We are afraid that many of the ignorant (al-juhhāl) will be seduced (yaghtarr $\bar{u})$ by this and so leave their religion ( $f a-y a k h r i j u$ ' an dinihim) due to their lack of knowledge of its mysteries. So let us desist from revealing the mysteries of the forms of worship of the People of the Book (ižnār asrār ta' abbudāt ahl al-kitāb).

52 See e.g. al-Qūnawī, $I^{\prime} j \bar{a} z, 11$ :

At this station [namely, the station of Muhammad] there are mysteries (asrār) that have been covered up (sutirat) by affirmation and denial, and which have been 


\section{The Perfect Human}

affirmed [only] at their level, out of fear of revealing them (iz̧hārihā) at an improper time, and prior to the [reader's] attainment of their level. Had it been permissible to divulge them (ifsha' 'uhā), they would have been revealed to you, and their signs would have been recited to you, but this is the mystery of His statement: "to make clear to people what has been sent down to them", (Q 16:44) and He did not say, "what has been sent down to you", nor "all that has been sent down upon you", and [it is the mystery of] other divine allusive sayings and pieces of wisdom: that He forbade (mana'a) the direct disclosure (al-tașrīh) of what was there. So it is necessary to take into account the divine indication (al-tanbìh al-ilāhì), and to stop at that.

53 See G. Hourani (tr.), Averroes: On the Harmony of Religion and Philosophy (Cambridge: Gibb Memorial Trust, 2012), 32-36, 114, note 191; Hodgson, Venture, 2:325; Brown, Misquoting, 222-223; Ahmed, What is Islam?, 167-168, 368-372.

54 Al-J̄̄ilì, al-Insān, 211.

55 Al-Shahrastān̄i, Book of Religious and Philosophical Sects: part 2, Containing the Account of Philosophical Sects, ed. W. Cureton (London: Society for the Publication of Oriental Texts, 1842), 133.

56 In a similar context in his Qāb al-qawsayn, al-Jīli likewise makes a reference to the associated concept of futuwwah, 'chivalry'. See Hoffman, "Annihilation in the Messenger", 358. For Ibn 'Arabī’s conception of adab, see D. Gril, “Adab and Revelation, or, One of the Foundations of the Hermeneutics of Ibn "Arabi", in Muhyiddin Ibn 'Arabi: A Commemorative Volume, ed. S. Hirtenstein and M. Tiernan (Shaftsbury, UK: Element for the Muhyiddin Ibn 'Arabi Society, 1993), 228-263.

57 This conclusion, it should be noted, is in keeping with Valerie Hoffman's finding that al-Jīlî̀'s writings - particularly his Qāb al-qawsayn and al-Kamālāt al-ilāhiyyah constitute an early instance of the appearance of the Sufi idea of 'annihilation in the Messenger' (al-fan $\bar{a}$ ' $f \grave{\imath}$ al-rasül), an idea which essentially denotes the mystic becoming a locus of manifestation for the Muhammadan Reality, and which subsequently became an important feature of early modern Sufism. See Hoffman, "Annihilation in the Messenger".

58 Al-Jīlì, al-Insān, 26 (my emphasis).

\section{Bibliography}

Abrahamov, Binyamin. Ibn al- 'Arabī and the Sufis. Oxford: Anqa Publishing, 2014.

'Afìfi, Abū al-'Alá. The Mystical Philosophy of Muhyid Dín Ibnul 'Arabí. Cambridge: University Press, 1939.

Ahmed, Shahab. What is Islam? The Importance of Being Islamic. Princeton, NJ: Princeton University Press, 2016.

Altmann, Alexander. "Homo Imago Dei in Jewish and Christian Theology", Journal of Religion 48, no. 3 (1968), pp. 235-259.

Amir-Moezzi, Mohammad A. The Divine Guide in Early Shi 'ism: The Sources of Esotericism in Islam. Translated by David Streight. Albany, NY: State University of New York Press, 1994.

'Aț̣ār, Farīd al-Dīn. Tadhkirat al-awliyā'. Edited by Muḥammad Isti'lāmī. Tehran: Intishārāt-i Zawār, 1392 SH [=2013].

Böwering, Gerhard and Yousef Casewit (eds). A Qur'an Commentary by Ibn Barrajān of Seville (d. 536/1141): Ị̇̂̄h al-hikma bi-ahkām al-ibra (Wisdom Deciphered, the Unseen Discovered). Leiden: Brill, 2015.

Brown, Jonathan A.C. Misquoting Muhammad: The Challenge and Choices of Interpreting the Prophet's Legacy. London: Oneworld Academic, 2015. 
Chittick, William C. "The Chapter Headings of the Fusûs", Journal of the Muhyiddin Ibn 'Arabi Society 2 (1984), pp. 41-94.

Chodkiewicz, Michel. Seal of Saints: Prophethood and Sainthood in the Doctrine of Ibn 'Arabī. Translated by Liadain Sherrard. Cambridge: Islamic Texts Society, 1999.

Ebstein, Michael. Mysticism and Philosophy in al-Andalus: Ibn Masarra, Ibn al-'Arabī and the Ismā 'ìlì Tradition. Leiden: Brill, 2014.

Ebstein, Michael. “Was Ibn Qasī a Șūfî?” Studia Islamica 110 (2015), pp. 196-232.

Farghān̄̄, Sa'd al-Dīn. Muntahá al-madārik fì sharh Tā'iyyat Ibn al-Fāriḍ. Edited by 'Āṣim al-Kayyālī. Beirut: Dār al-Kutub al-'ilmiyyah, 2007.

Gomaa, 'Ali. Responding From the Tradition: One Hundred Contemporary Fatwas by the Grand Mufti of Egypt. Translated by Nuri Friedlander and Tarek Elgawhary. Louisville, KY: Fons Vitae, 2011.

Goodman, Martin. A History of Judaism. London: Allen Lane, 2018.

Gril, Denis. "Adab and Revelation, or, One of the Foundations of the Hermeneutics of Ibn 'Arabi", Muhyiddin Ibn 'Arabi: A Commemorative Volume. Edited by Stephen Hirtenstein and Michael Tiernan. Shaftsbury, UK: Element for the Muhyiddin Ibn 'Arabi Society, 1993, pp. 228-263.

Ḥakīm, Su'ād. Al-Mu 'jam al-șüfi: al-hikmah fì huudūd al-kalimah. Beirut: Dandarah li-alțabā'ah wa-al-nashr, 1981.

Hodgson, Marshall. The Secret Order of Assassins: The Struggle of the Early Nizârî Ismâ 'îlîs Against the Islamic World. The Hague: Mouton \& Co., 1955.

Hodgson, Marshall. The Venture of Islam: Conscience and History in a World Civilization, in three volumes. Chicago, IL; London: University of Chicago Press, 1974.

Hoffman, Valerie. "Annihilation in the Messenger of God: The Development of a Sufi Practice”, International Journal of Middle East Studies 31, no. 3 (1999), pp. 351-369.

Hourani, Albert. A History of the Arab Peoples (updated edition). Introduced by Malise Ruthven. London: Faber \& Faber, 2013.

Hourani, George (tr.). Averroes: On the Harmony of Religion and Philosophy. Cambridge: Gibb Memorial Trust, 2012.

Ibn 'Arabī, al-Futūhāt al-Makkiyyah, in four volumes. Egypt: Dār al-Kutub al-'arabiyyah al-kubrá, 1329 AH [=1911].

Ibn 'Arabī. Fuṣūṣ al-ḥikam. Edited by Abū al-'Alá 'Afĩfì. Beirut: Dār al-Kitāb al-'Arab̄̄, 1946.

Ibn 'Arabī. Rasā'il Ibn 'Arabī, in two volumes. Hyderabad: Maṭba'at Jam'iyyat Dā'irat al-ma'ārif al-'uthmaniyyah, 1948.

'Irāqī, Fakhr al-Dīn. Kulliyāt-i Fakhruddīn-i 'Irāqū. Edited by Sa‘īd Nafìsī. Tehran: Kitābkhāna-yi Sanā'1̄, 1338 SH [=1956/1957].

Izutsu, Toshihiko. Sufism \& Taoism: A Comparative Study of Key Philosophical Concepts. Berkeley, CA; London: University of California Press, 1984.

Jāmī, 'Abd al-Raḥmān. Sharh al-Jāmī 'alá Fușuṣ al-ḥikam. Edited by 'Āṣim al-Kayyālī. Beirut: Dār al-Kutub al-'ilmiyyah, 2004.

Jamil, Nadia. "Caliph and Qutb. Poetry as a Source for Interpreting the Transformation of the Byzantine Cross on Steps on Umayyad Coinage", Bayt al-Maqdis, Jerusalem and Early Islam: Oxford Studies in Islamic Art 9, Part Two. Edited by Jeremy Johns. Oxford: Oxford University Press, 1999, pp. 11-57.

Jamil, Nadia. Ethics and Poetry in Sixth Century Arabia. Trumpington, UK: E.J.W. Gibb Memorial Trust, 2018.

Jeffrey, Arthur. "Ibn 'Arabī’s Shajarat al-kawn”, Studia Islamica 10 (1959), pp. 43-77, 11 (1960), pp. 113-160. 


\section{The Perfect Human}

Jīlī, 'Abd al-Karīm. Al-Insān al-kāmil fì ma 'rifat al-awākhir wa-al-awā'il. Edited by Șalāh ibn Muḥammad 'Uwayḍah. Beirut: Dār al-Kutub al-'ilmiyyah, 1997.

Jīlī, 'Abd al-Karīm. Al-Kamālāt al-ilāhiyyah fì al-sîā̄t al-muhammadiyyah. Edited by Sa 'īd 'Abd al-Fattāh. Cairo: 'Ālam al-fikr, 1997.

Karamustafa, Ahmet. Sufism: The Formative Period. Berkeley, CA: University of California Press, 2007.

Lévy, Carlos. "Philo of Alexandria", The Stanford Encyclopaedia of Philosophy, online edition.

Lo Polito, Nicholas. 'Abd al-Karìm al-Jīlī: Tawhịd, Transcendence, and Immanence. Doctoral thesis, University of Birmingham, 2010.

Nicholson, Reynold A. Studies in Islamic Mysticism. Richmond, UK: Curzon Press, 1921.

Qāshānī, 'Abd al-Razzāq. Sharh 'alá Fuṣūṣ al-hikam. Egypt: al-Maṭba'ah al-Yamaniyyah, (no date).

Qayșarī, Dāwūd. Sharḥ-i muqaddamah- 'i Qayșarī bar Fuṣ̂̄ṣ al-hikam-i Muhȳi al-Dīn 'Arabī. Edited by Jalāl al-Dīn Āshtiyānī. Mashhad: Kitābfurūshī-yi bāstān, $1350 \mathrm{SH}$ $[=1966]$.

Qūnawī, Șadr al-Dīn. I'jāz al-bayān fì tafsīr umm al-Qur'ān. Edited by Jalāl al-Dīn Āshtiyānī. Qom: Mu'assasah-yi Būstān-i Kitāb-i Qom, 1380 SH/1423 AH [=2002].

Rubin, Uri. "Pre-Existence and Light: Aspects of the Concept of Nur Muhammad", Israel Oriental Studies 5 (1975), pp. 62-119.

Shahrastānī, Muhammad. Book of Religious and Philosophical Sects: part 2, Containing the Account of Philosophical Sects. Edited by William Cureton. London: Society for the Publication of Oriental Texts, 1842.

Tahānawī, Muḥammad. Kashshāf iștilāḥāt al-funūn. Edited by Luṭ̂ī 'Abd al-Badī', 'Abd al-Mun'im Husayn, and Amīn Khūlī. Cairo: al-Mu'assasah al-Mișrīyah al-'āmmah li-lta'līf wa-al-tarjamah wa-al-țibā' ah wa-al-nashr, 1963.

Takeshita, Masataka. Ibn 'Arabi's Theory of the Perfect Man and its Place in the History of Islamic Thought. Doctoral thesis, University of Chicago, IL, 1987.

Todd, Richard. The Sufi Doctrine of Man: Șadr al-Dīn al-Qūnawī's Metaphysical Anthropology. Leiden: Brill, 2014.

Zabīdī, al-Sharjī. Țabaqāt al-khawāṣṣ ahl al-șidq wa-al-ikhlāṣ. Sana'a; Beirut: al-Dār alYamaniyyah li-al-nashr wa-al-tawzī‘ 1986. 
(täbi) [of his]. So the category of legislative prophethood (nubuwwat al-tashrī) was cut off after him, and Muhammad was the Seal of Prophets, because he brought perfection, which no one else brought. ${ }^{82}$

Whatever the exalted metaphysical status and spiritual powers of the 'Perfect Ones', then, for al-Jīli there is only one true Perfect Human, and that is the Prophet Muhammad. At the very end of al-Insān al-kāmil, he brings this all together, leaving us in no doubt that Muhammad is the most perfect of the Perfect Humans and, in fact, a quasi-divine being:

The means (wasilah) [of attaining 'realisation' (al-tahaqquq)] of all of the prophets and Friends of God is Muhammad - May God bless him and grant him peace. So the means is the station of proximity (maqām al-qurbah) itself. And the first of its stations is the station of friendship (maqām alkhillah), and the end of the station of the Friend (maqām al-khalīl) [namely, Abraham] is the beginning of the station of the Beloved (maquam al-habìb) [namely, Muhammad], for the essential Beloved (al-habīb al-dhātī) is an expression of unitive loving desire (al-ta 'ashshuq al-ittihāad $)$, so each of the two lovers (al-muta 'ashshiqayn) [namely, Muhammad and God] appears in the form of the other, and each stands in the station of the other ... It was to this that $\mathrm{He}$ - Glory be to Him and may He be exalted - referred in His majestic Book, when He said to Muhammad - May God bless him and grant him peace: "Those who pledge allegiance to you [namely, Muhammad] only pledge allegiance to God", (Q 48:10) whereby He stood Muhammad in His own station (aqāma Muhammad maqām nafsihi), and when He said: "Whoever obeys the Messenger has obeyed God." (Q 4:80) Subsequently Muhammad spoke openly to Abū Sa'īd al-Khudrī when he saw him in his sleep and said to him: "O Messenger of God, forgive me, for loving God (mahabbat Allāh) has distracted me (shaghalatnī) from loving you (mahabbatika)." And he [namely, Muhammad] said to him: "O blessed one, loving God is loving me (mahabbat Alläh mahabbatī)." For just as Muhammad May God bless him and grant him peace - was a viceregent (khaliffah) of God, so too was God here a deputy (na'iban) of Muhammad, and a deputy is a viceregent, and a viceregent is a deputy. So this one was that one and that one was this one (dhāka huwa hādha wa-hādha huwa dhāka). Due to this, Muhammad - May God bless him and grant him peace - was made unique (tafarrada) in his perfection, so he sealed (khatama) the perfections and the divine stations in his inner nature, and his sealing of the station of messengership in his outer nature testifies to that. ${ }^{83}$

\section{Notes}

1 See Takeshita, Ibn 'Arabì's Theory, 50.

2 Ibn 'Arabī, Futūhāt, 2:391. See also Chittick, Sufi Path of Knowledge, 276.

3 See Nettler, Sufi Metaphysics, 18. 
4 Jāmī, Naqd al-nușūs fì sharh naqsh al-Fuṣūṣ, ed. A al-Kayyālī (Beirut: Dār al-Kutub al-'ilmiyyah, n.d.), 70; W. Chittick, "Ibn 'Arabī’s Own Summary of the Fușūṣ: 'The Imprint of the Bezels of Wisdom'”, Sophia Perennis 1, no. 2 (1975), 88-128, 94.

5 Cf. Maimonides, Guide, 1:40 [I 14]: "The equivocality of the word Adam. It is the name of Adam the first man ... It is also the term designating the species."

6 Quoted in Chittick, "Chapter Headings", 49.

7 Al-Qāshānī, Sharh, 8.

8 Al-Qayșarī, Sharḥ, 268.

9 See C. Addas, Quest for the Red Sulphur: The Life of Ibn 'Arabī, tr. P. Kingsley (Cambridge: Islamic Texts Society, 1993), 87-88; S. Shaikh, Sufi Narratives of Intimacy: Ibn 'Arabī, Gender, and Sexuality (Chapel Hill, NC: University of North Carolina Press, 2012), 99-102.

10 Ibn 'Arabī, Futūhāt, 3:89; Chodkiewicz, Seal, 98; Addas, Quest, 87; al-Hakīm, al$M u$ 'jam, 143. For a modern Islamic feminist reading of this and similar passages, see S. Shaikh, "In Search of al-Insān: Sufism, Islamic Law, and Gender", Journal of the American Academy of Religion 77 (2009), no. 4, 781-822, 806-809.

11 See al-Hakīm, al-Mu'jam, 189-191; Chodkiewicz, Seal, 103-104; Ridgeon, 'Azīz Nasafì, 188-190. Ebstein, Mysticism and Philosophy, 134; Hujwīrī had also earlier

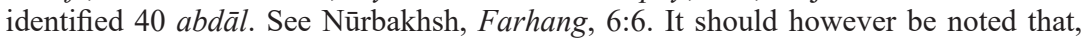
elsewhere in his writings, Ibn 'Arabī identifies seven abdāl. See e.g. Ibn 'Arabī, Futūhāt, 1:160, 2:7. In identifying seven, he was following, among others, al-Hakīm Tirmidhī. See Radtke and O'Kane, The Concept of Sainthood, 109-110.

12 Ibn 'Arabī, Futūhāt, 2:9.

13 Ibid., 1:679.

14 Ibn 'Arabī, Fușūss 217.

15 See ibid.; Ibn 'Arabī, Futūhāat, 1:679, 3:87; al-Ḥakīm, al-Mu 'jam, 144-145.

16 Al-Qāshānī, Sharh, 267-268. For a later expression of a similar idea, see also al-Nābulusī, Sharh jawāhir al-nușūs fi hall kalimāt al-Fușūs, two volumes in one (Egypt: Maṭba'at al-Zamān, 1887-1905), 315: "The Perfect Human was created from the Real - May He be exalted - and the woman (al-mar'ah) was created from the Perfect Human. So the Real loved the Perfect Human and the Perfect Human loved the woman."

17 Ibn 'Arabī, Futūhāat, 1:679.

$18 \mathrm{Ibn}$ 'Arabī, Futūhăt, 3:87. This notion that women are lesser than men in religion and intellect is found in a hadith recorded in Bukhārī. See R. Cornell, "Sufi Women's Spirituality: A Theology of Servitude", Voices of Islam, volume 1: Voices of Tradition, ed. V. Cornell (Westport, CT; London: Praeger, 2007), 167-174, 171.

19 This being said, I personally know of no instance in which Ibn 'Arabī or his leading interpreters use the term 'al-insān al-kāmil' of a woman.

20 Ahmed, What is Islam?, 79.

21 Quoted in Todd, Sufi Doctrine, 58.

22 See Chittick, Sufi Path of Knowledge, 91-94; Izutsu, Sufism \& Taoism, 33-35.

23 Q 17:20: "We bestow those gifts of your Lord on all, there is no gift of your Lord that is prohibited [to anyone]."

24 Ibn 'Arabī, Futūhāat, 1:287; Chittick, Sufi Path of Knowledge, 91-92.

25 Connected to this, Ibn 'Arabī and his interpreters often refer to a three-tiered hierarchy among human beings. Thus Ibn 'Arabī writes, for instance, of the difference between the creeds of the masses ('aqìdat al-'awāmm), of the elect of the people of God (khawāṣs ahl Allāh), and of the "quintessence of the elect" (khulāṣat al-khawāsșs), for which see Abū Zayd, Hākadhā, 105-106. See also G. Schubert (ed.), Al-Murāsalāt bayn Șadr al-Dīn al-Qūnawì wa-Nāșir al-Dīn al-Ṭūsī (Beirut: Dār alNashr, 1995), 16, for a three-tiered scheme set out by al-Qūnawī.

26 See e.g. Ibn 'Arabī, Futūhāt, 2:396, and the passages quoted in Takeshita, Ibn 'Arabī's Theory, 109-112. Interestingly, the concept of the 'animal human' does not appear to be an important one in the Qūnawī tradition. Thus al-Qāshānī, for instance, 
does not include the term al-insān al-hayawān in his lexicon of Sufi metaphysical technical terms, nor does he discuss the term in his commentary on the passage of the Fușūṣ in which the term appears. See al-Qāshānī, Sharh, 253.

27 Ibn 'Arabī, Futūḥ̄t , 3:437; al-Hakīm, al-Mu 'jam, 156.

28 Ibn 'Arabī, Futūḥāt, 3:296; al-Hakīm, al-Mu 'jam, 156-157; Takeshita, Ibn 'Arabī's Theory, 110-111; Ebstein, Mysticism and Philosophy, 187.

29 See Ibn 'Arabī, Fușūs, 168, quoted in Takeshita, Ibn 'Arabī's Theory, 113.

30 Ibn 'Arabī, Fușūs, 199. See also Takeshita, Ibn 'Arabī's Theory, 112.

31 See Ibn 'Arabì, Fușūs, 57-58 and passim. For the meaning of hikmah in Ibn 'Arabī's writings, see Rosenthal, "Ibn 'Arabī”, 13-14.

32 See Izutsu, Sufism \& Taoism, 236.

33 Al-Qāshānī, Sharḥ, 8.

34 Ibid., 242.

35 Ibid., 266.

36 Ibid.

37 Frank Griffel has suggested that Ibn 'Arabī's idea of prophecy has roots in the Avicennian philosophical conception of prophecy as an intense form of intellectual attainment, which, like Ibn 'Arabî's conception, served to reduce the gap between prophets and other human beings. F. Griffel, "Muslim Philosophers' Rationalist Explanation of Muhammad's Prophecy", The Cambridge Companion to Muhammad, ed. J.E. Brockopp (New York; Cambridge: Cambridge University Press, 2010), 158-179, 178.

38 For Ibn 'Arabī's distinction between the two types of prophethood, see Ibn 'Arabī, Fușūss, 62-64, 131; Takeshita, Ibn 'Arabī's Theory, 118-131; al-Hakīm, al-Mu 'jam, 1038-1053; Chodkiewicz, Seal, 50-51, 114-115; Y. Friedmann, Prophecy Continuous: Aspects of Ahmadī Religious Thought and Its Medieval Background (Berkeley, CA; London: University of California Press, 1989), 71-76; Nettler, Sufi Metaphysics, 142-145; Abū Zayd, Hākadhā, 60-72.

39 Ibn 'Arabī, Futūhāat, 2:3.

40 Schubert, al-Murāsalāt, 16.

41 Ibid., 21.

42 Al-Qayșarī, Sharh, 491.

43 For this claim and the concept of the 'Seal of Sainthood', see Chodkiewicz, Seal, 128146; Addas, Quest, 77-81; al-Hakim, al-Mu jam, 378-382; Lipton, Rethinking, 46-47.

44 See e.g. al-Qāshānī, Sharḥ, 2, where he describes Ibn 'Arabī as "the perfected, perfect shaykh" (al-shaykh al-kāmil al-mukammal). Similarly, al-Qūnawī’s student al-Jandī refers to his teacher as "the Perfect Man of his age, the Pole of the Poles of the time and the khalifah of the Seal of Muhammadan Sanctity (Ibn 'Arabi)". Quoted in Chittick, "Last Will and Testament", 45.

45 Izutsu, Sufism \& Taoism, 236. See also Afîfī, Mystical Philosophy, 72: "Each prophet in the Fusûs is called a 'logos' but not the Logos - the latter term being preserve for the 'head' of the hierarchy - i.e. Mohammed." For the Ibn 'Arabian conception of the logos, see Chapter 2 of this book.

46 Al-Ghazālī, Kìmīyā-yi sa' $\bar{a} d a t, 28$. The three qualities are: (1) that to the prophet is unveiled (kashf shavad) in wakefulness (bïdärī) that which is unveiled to the common people in sleep; (2) that while the souls of the common people only affect their own bodies, the soul of the prophet affects the bodies of others; (3) that the prophet gets to know forms of knowledge ( 'ulüm) that the common people learn through instruction through his inner reality (bātin-i khwìsh).

47 Ibn 'Arabī, Futūhāt, 1:151, Chodkiewicz, Seal, 94.

48 See esp. in this regard Ibn 'Arabī, Futūh $h \bar{a} t, 3: 142$, where Ibn 'Arabī refers to how the Muhammadan Reality "extends to every Perfect Human".

49 Quoted in Chittick, "Chapter Headings", 86. See also al-Qāshānī, Sharh, 267: "The Greatest Name is only with our Prophet Muhammad - May God bless him and grant him peace - and not with any of the other prophets." 
50 Ibn 'Arabī, Fuṣūṣ, 110.

51 Ibid., 214.

52 Ibn 'Arabī, Futūhāt, 4:433; al-Hakìm, al-Mu 'jam, 500. See also the passages from the Futūhāt quoted in al-Hakīm, al-Mu 'jam, 278: "He [namely, Muhammad] is the most complete synthesis (al-majmū' al-tāmm) and the most perfect exemplar (al-barnāmaj alakmal)", and Hoffman, "Annihilation in the Messenger", 353, where he similarly informs us that "the manifestation of the Real in the mirror of Muhammad is the most perfect, most balanced, and most beautiful manifestation, because of his mirror's particular qualities".

53 Al-Farghān̄i, Muntahá al-madārik, 41.

54 Al-Qāshānī, Mu jam, 162.

55 Al-Qāshānī, Sharh, 267.

56 See Lipton, Rethinking, 77.

57 See Ibn 'Arabī, Futūhà

58 See esp. ibid., 3:141-146 (ch. 337). For "the keys to the unseen" and related concepts in Ibn 'Arabī's thought, see Hakīm, al-Mu 'jam, 863-870. For "the all-comprehensive words" motif, see Hakīm, al-Mu'jam, 274-276; Chittick, Sufi Path of Knowledge, 239; Lipton, Rethinking, 39-40. Ibn 'Arabī explains that Muhammad being given "the all-comprehensive words" means that, while Adam was taught the names of all things (see Q 2:31), Muhammad was taught the meanings (musammiyyāt, ma 'ān $\bar{\imath}$ ) of those names. See Ibn 'Arabī, Fușūs, 214; al-Sha'rānī, al-Kibrīt, 10.

59 Al-Jīlì, al-Insān, 207.

60 Quoted in Goichon, Lexique, 219. Cf. Maimonides, Guide, 1:113 (I 51): "For every notion superadded to an essence is an adjunct to it and does not perfect its essence, and this is the meaning of accident."

61 Cf. Maimonides, Guide, 1:73 (I 34):

For man is not granted his ultimate perfection [kamālahu al-akhīr] at the outset; for perfection exists in him only potentially [bi-al-quwwah], and in his beginnings he lacks this act ... Nor is it necessarily obligatory in the case of every individual who is endowed with some thing in potency, that this thing should become actual [yakhruj dhālik ilá al-fi' 'l].

62 See also al-Jīlì, al-Insān, 78, where he explains that the Perfect Human is the individual "in whom [the divine] life (al-hayāt) appears in its complete form ('alá suuratiha al-tämmah)", whereas the individual "in whom life appears, but in a form that is not complete", is called 'the perfect animal human' (al-insān al-kāmil al-hayayānī). This, of course, evokes Ibn 'Arabī's distinction between the Perfect Human and the animal human.

63 In his al-Kamālāt al-ilāhiyyah, meanwhile, al-Jîli explains the ability of some individuals and not others to manifest perfection in terms of the Ibn 'Arabian (and Avicennian) concept of 'preparedness' (isti ‘dād). See al-Jīlī, al-Kamālāt, 332. See also chapter four of Qāb al-qawsayn, on 'The distinctiveness of his [namely, Muhammad's] receptivity from the receptivity of every other existent'.

64 Al-Jīlì, al-Insān, 207-208.

65 See al-J̄ilì, al-Kamālāt, esp. 64-314.

66 Ibid., 325.

67 Quoted in Nabhānī, Jawāhir, 1:1496. See also ibid., 1:1499, and the quotation from the same work in Hoffman, "Annihilation in the Messenger", 356: "God the Exalted has set apart Muhammad, God's blessings and peace be upon him, for the greatest and most perfect divine manifestations which no other capacity can accept in this world or the next."

68 Ibid., 262-263.

69 Al-Jīlīi, al-Kamālāt, 325.

70 Al-Jīli expresses this same idea from a somewhat different perspective in $Q \bar{a} b$ alqawsayn, where he declares that the only way to reach God is through Muhammad. See Nabhān̄̄, Jawāhir, 1:1498; Hoffman, "Annihilation in the Messenger", 356. 
71 The term al-furqān usually denotes another name for the Qur'an. See e.g. Q 25:01, 2:185.

72 Al-Jīilì, al-Insān, 127.

73 See F. Morrissey, 'Abd al-Karìm al-Jīlī's Sufi Metaphysical Treatment of the Scriptures in 'al-Insān al-kāmil' (Doctoral thesis, University of Oxford, 2018).

74 Al-Jīilì, al-Insān, 125.

75 It should be noted, however, that, other than his emphasis on the superiority of Muhammad, al-Jīlin never sets out this hierarchy in explicit terms. Furthermore, the hierarchy of prophets is also complicated by the fact that, in the course of his description of his mystical ascension in chapter 61, al-Jîli places Moses in the sixth heaven (as in traditional accounts of the Prophet's mi 'rajj), and Jesus and David in the fourth heaven. See ibid., 237-238.

76 Ibid., 265-266.

77 Ibid., 91.

78 Ibid., 265.

79 Ibid., 265.

80 It should here be noted that, as we saw above, prior to the age of the historical Muhammad non-Muslims such as Plato were able to become perfect Friends of God, in al-Jîlî̀'s view.

81 See al-Jīlīi, Sharh, 83. See also ibid., 66, where he describes Ibn 'Arabī as 'The Greatest Friend of God' (al-waliy al-akbar), 'The Most Splendid and Most Magnificent Pole' (al-qutb al-a 'zam al-afkhar), 'The Locus of Appearance of the [Divine] Attribute of Knowledge' (mazhar al-sifah al-'ilmiyyah), 'The Locus of Manifestation of [God's] Essential and Governing Perfections' (majlā al-kamālāt al-'ayniyyah wa-alhukmiyyah), 'The Tongue of Reality' (lisān al-haqīqah), and 'The Master of the Path' (ustādh al-tarīqah).

82 Al-Jīlī, al-Insān, 119-120.

83 Ibid., 279.

\section{Bibliography}

Abū Zayd, Nașr H. Hākadhā takallama Ibn 'Arabī. Casablanca; Beirut: Dār al-Thaqāfì al-'Arabī, 2006.

Addas, Claude. The Quest For the Red Sulphur. Translated by Peter Kingsley. Cambridge: Islamic Texts Society, 1993.

'Afĩfì, Abū al-'Alá. The Mystical Philosophy of Muhyid Dín Ibnul 'Arabí. Cambridge: University Press, 1939.

Ahmed, Shahab. What is Islam? The Importance of Being Islamic. Princeton, NJ: Princeton University Press, 2016.

Chittick, William C. "Ibn 'Arabī's Own Summary of the Fușuss: 'The Imprint of the Bezels of Wisdom'”, Sophia Perennis 1, no. 2 (1975), pp. 88-128.

Chittick, William C. "The Last Will and Testament of Ibn 'Arabi's Foremost Disciple, Sadr al-Din Qunawi”, Sophia Perennis 4, no. 1 (1978), pp. 43-58.

Chittick, William C. "The Chapter Headings of the Fusûs", Journal of the Muhyiddin Ibn 'Arabi Society 2 (1984), pp. 41-94.

Chittick, William C. The Sufi Path of Knowledge: Ibn al- 'Arabi's Metaphysics of Imagination. Albany, NY: State University of New York Press, 1989.

Chodkiewicz, Michel. Seal of Saints: Prophethood and Sainthood in the Doctrine of Ibn 'Arabī. Translated by Liadain Sherrard. Cambridge: Islamic Texts Society, 1999.

Cornell, Rkia. "Sufi Women's Spirituality: A Theology of Servitude", Voices of Islam, volume 1: Voices of Tradition. Edited by Vincent Cornell. Westport, CT; London: Praeger, 2007, pp. 167-174. 
Ebstein, Michael. Mysticism and Philosophy in al-Andalus: Ibn Masarra, Ibn al-'Arabī and the Ismā 'îlì Tradition. Leiden: Brill, 2014.

Farghānī, Sa'd al-Dīn. Muntahá al-madārik fì sharh Tã'iyyat Ibn al-Fāriḍ. Edited by 'Āṣim al-Kayyālī. Beirut: Dār al-Kutub al-'ilmiyyah, 2007.

Friedmann, Yohanan. Prophecy Continuous: Aspects of Ahmadī Religious Thought and Its Medieval Background. Berkeley, CA; London: University of California Press, 1989.

Ghazālī, Abū Ḥāmid. Kitāb-i Kìmīyāayi sa'ādat. Edited by Aḥmad Ārām. Tehran: Chapkhānah-yi Markazī, 1954.

Goichon, Amélie M. Lexique de la langue philosophique d'Ibn Sīnā (Avicenne). Paris: Desclée de Brouwer, 1938.

Griffel, Frank. "Muslim Philosophers' Rationalist Explanation of Muhammad's Prophecy", The Cambridge Companion to Muhammad. Edited by Jonathan E. Brockopp (New York; Cambridge: Cambridge University Press, 2010), pp. 158-179.

Hakīm, Su'ād. Al-Mu 'jam al-șüfi: al-hikmah fì ḥudūd al-kalimah. Beirut: Dandarah li-alțabā'ah wa-al-nashr, 1981.

Hoffman, Valerie. "Annihilation in the Messenger of God: The Development of a Sufi Practice", International Journal of Middle East Studies 31, no. 3 (1999), pp. 351-369.

Ibn 'Arabī. al-Futūhāat al-Makkiyyah, in four volumes. Egypt: Dār al-Kutub al-'arabiyyah al-kubrá, 1329 AH [=1911].

Ibn 'Arabī. Fușūs al-ḥikam. Edited by Abū al-'Alá 'Afìfĩ. Beirut: Dār al-Kitāb al-'Arabī, 1946.

Izutsu, Toshihiko. Sufism \& Taoism: A Comparative Study of Key Philosophical Concepts. Berkeley, CA; London: University of California Press, 1984.

Jāmī, 'Abd al-Raḥmān. Naqd al-nușūṣ fì sharh naqsh al-Fuṣūṣ. Edited by 'Āṣim al-Kayyālī. Beirut: Dār al-Kutub al-'ilmiyyah, no date.

Jīlī, 'Abd al-Karīm. Al-Insān al-kāmil fì ma'rifat al-awākhir wa-al-awā'ill. Edited by Ṣalāḥ ibn Muḥammad 'Uwayḍah. Beirut: Dār al-Kutub al-'ilmiyyah, 1997.

Jīlī, 'Abd al-Karīm. Al-Kamālāt al-ilāhiyyah fì al-șifāt al-muhammadiyyah. Edited by Sa '̄id 'Abd al-Fattāh. Cairo: 'Ālam al-fikr, 1997.

Jīlī, 'Abd al-Karīm. Sharh mushkilāt al-Futūhāat al-Makkiyyah. Edited by Youssef Ziedan. Cairo: Dār al-Amīn, 1999.

Lipton, Gregory. Rethinking Ibn 'Arabi. New York: Oxford University Press, 2018.

Maimonides, Moses. The Guide of the Perplexed. Translated and introduced by Shlomo Pines, with an introductory essay by Leo Strauss. Chicago, IL: University of Chicago Press, 1963.

Nabhānī, Yūsuf. Jawāhir al-bihâ̄r fì faḍā'il al-nabī al-mukhtār, in four volumes. Edited by Muḥammad al-Ḍannāwī. Beirut: Dār al-Kutub al-'ilmiyyah, 1998.

Nābulusī, 'Abd al-Ghanīy. Sharh jawāhir al-nușūs fì hall kalimāt al-Fușūṣ, two volumes in one. Egypt: Mațba'at al-Zamān, 1887-1905.

Nettler, Ronald L. Sufi Metaphysics and Qur'ānic Prophets: Ibn 'Arabī's Thought and Method in the Fuṣuṣ al-ḥikam. Cambridge: Islamic Texts Society, 2003.

Nūrbakhsh, Javād. Farhang-i Nürbakhsh (ișțilāhătt-i tașawwuf), in eight volumes. Tehran: Chāpkhāneh-yi Marvī, 1371 SH [= 1992/1993].

Qāshānī, 'Abd al-Razzāq. Sharh 'alá Fuṣūṣ al-hikam. Egypt: al-Maṭba'ah al-Yamaniyyah, (no date).

Qāshānī, 'Abd al-Razzāq. Mu 'jam iștilāḥāt al-ṣufiyyah. Edited by 'Abd al-'Āl Shāhīn. Cairo: Dār al-Manār, 1992.

Qayșarī, Dāwūd. Sharḥ-i muqaddamah- 'i Qayșarī bar Fușūṣ al-ḥikam-i Muhyī al-Dīn 'Arabī. Edited by Jalāl al-Dīn Āshtiyānī. Mashhad: Kitābfurūshī-yi bāstān, 1350 SH [=1966]. 
Radtke, Bernd and John O'Kane. The Concept of Sainthood in Early Islamic Mysticism: Two Works by Al-Hakim Al-Tirmidhī. Abingdon, UK: Routledge, 1996.

Ridgeon, Lloyd. 'Azīz Nasafì. Richmond, UK: Curzon, 1998.

Rosenthal, Franz. 'Ibn 'Arabī between 'Philosophy' and 'Mysticism': 'Sūfism and Philosophy are Neighbors and Visit Each Other': fa-inna at-tașawwuf wa-t-tafalsuf yatajāwarāni wa-yatazāwarāni”, Oriens 31 (1988), pp. 1-35.

Schubert, Gudrun (ed.). Al-Murāsalāt bayn Șadr al-Dīn al-Qūnawī wa-Nāșir al-Dīn al-Ṭūsì (Beirut: Dār al-Nashr, 1995.

Shaikh, Sa 'diyyah. "In Search of al-Insān: Sufism, Islamic Law, and Gender", Journal of the American Academy of Religion 77 (2009), no. 4, pp. 781-822.

Shaikh, Sa'diyya. Sufi Narratives of Intimacy: Ibn 'Arabī, Gender, and Sexuality. Chapel Hill, NC: University of North Carolina Press, 2012.

Sha'rān̄̄, 'Abd al-Wahhāb. Al-Kibrīt al-aḥmar fì bayān 'ulūm al-shaykh al-akbar. Edited by 'Abd Allāh Mạ̣mūd Muḥammad 'Umar. Beirut: Dār al-Kutub al-'ilmiyyah, 1998.

Takeshita, Masataka. Ibn 'Arabi's Theory of the Perfect Man and its Place in the History of Islamic Thought. Doctoral thesis, University of Chicago, IL, 1987.

Todd, Richard. The Sufi Doctrine of Man: Sadr al-Dīn al-Qūnawī's Metaphysical Anthropology. Leiden: Brill, 2014. 
wa-al-hadrāt), ${ }^{86}$ Ibn Khaldūn bases his presentation of Ibn 'Arabian Sufi metaphysics on al-Farghānī's commentary on Ibn al-Fāriḍ's Tā'iyyah, a text that Ibn Khaldūn probably knew through his friend Ibn al-Khațīb's (d. 1374) book on Sufism, Rawdat al-ta'rîf bi-al-hubb al-sharîf. ${ }^{87}$ Though, as we have seen, Ibn Khaldūn does briefly discuss the Ibn 'Arabian concept of the Pole (al-qutb), and associates the Poles with those whom he calls "the Perfect Ones (al-kummal) among the Muhammadans (al-muhammadiyyin)/among the people of the Muhammadan religious community (ahl al-millah al-muhammadiyyah)", ${ }^{88}$ nevertheless he makes no mention of the term al-insān al-kāmil. The reason for this, I think, is that Ibn Khaldūn was writing just prior to al-Jîl1̄i, ${ }^{89}$ using as his source an Ibn 'Arabian thinker - al-Farghān̄ - who did not put nearly so great an emphasis on the idea of the Perfect Human as al-Jīli did. It was only after al-Jīli that the idea of the Perfect Human came to be seen as an integral part of the Ibn 'Arabian Sufi metaphysical worldview. In both the significance that he accords to the idea and in the content of his idea of the Perfect Human, then, al-Jīli marks a new stage in the history of Sufi thought.

\section{Notes}

1 Hodgson, "How Did the Early Shî‘a", 2. A similar argument has been made by Valerie Hoffman, who proposes that the centrality of the Prophet and his family within modern Egyptian Sufism (perhaps under the influence of Ibn 'Arabian ideas) is possible evidence in support of Hodgson's statement. See Hoffman, "Devotion to the Prophet", 615.

2 Hodgson, Venture, 2:462.

3 See in this regard the hadiths of the Imams quoted in Amir-Moezzi, Divine Guide, 45-46; Amir-Moezzi, Spirituality, 105, 112. And on the Imami Shi i view of the Imam more generally, see Amir-Moezzi, Spirituality, 103-306.

4 In this regard, it should be noted that the Yemen-based Zaydī branch of Shī 'ism does not view the Imam in such exalted metaphysical terms as the Twelver or Ismaili Shi'ah, and was, moreover, actively hostile to Ibn 'Arabian Sufism. See E. Kohlberg, "Some Zaydi Views on the Companions of the Prophet", Bulletin of the School of Oriental and African Studies 39, no. 1 (1976), pp. 91-98, 91; al-Hiibshī, al-Șüfiyyah, 53-66; W. Madelung, "Zaydi Attitudes to Sufism", Islamic Mysticism Contested, ed. F. de Jong and B. Radtke (Leiden: Brill, 1999), pp. 124-144. In connection to al-Jîlī's Yemeni environment, therefore, a more profitable line of research might be to investigate parallels between al-Jīlì's idea of the Perfect Human and the conception of the Imam found in the literature produced by the Tayyibī Ismailis of Yemen. For Tayyibī Ismaili thought, see F. Daftary, The Ismailis: Their History and Doctrines (Cambridge: Cambridge University Press, 2007), 269-275; T. Mayer and W. Madelung (ed. and tr.), Avicenna's Allegory on the Soul: An Ismaili Interpretation (London: I.B. Tauris, 2015).

5 Thus Shi'i thinkers such as Ḥaydar Āmulī (d. after 1385), his student Ibn Abī Jumhūr al-Aḥsā’̄̄ (d. 1495/1496), and Mullā Șadrā (d. 1640), Muḥsin Fayḍ Kāshānī (d. 1680), and Quṭb al-Dīn Ashkiwārī (d. c. 1680) attempted to integrate Ibn 'Arabian Sufi metaphysical ideas into their Shî' 1 w worldview, including by identifying the Perfect Humans with the Shī‘i Imams. See Amir-Moezzi, Spirituality, 107-113; S. Kamada, "Walāya in Fayḍ Kāshān̄”, Reason and Inspiration in Islam: Theology, Philosophy, and Mysticism in Muslim Thought, ed. T. Lawson (London: I.B. Tauris, 2005), 455-468; M. Terrier, "Le Maḥbûb al-qulûb de Quṭb al-Dîn Ashkevarî: Une œuvre méconnue 
dans l'histoire de l'histoire de la sagesse en islam", Journal Asiatique 298, no. 2 (2010), 345-387.

6 Nürbakhsh's thought and the movement that he inspired, it should be noted, were part of a broader trend in Persian Islam in the fourteenth and fifteenth centuries, which saw the emergence of several mystical-messianic movements with political programmes, which adopted and reworked ideas found in earlier esoteric or 'extremist' (ghulāt) Shī'ism and in Șūfism. Among such movements were the Sarbadārs, the Hurūfîs, the Nuqtavīs, and, most famously and successfully, the Safavids. See B.S. Amoretti, "Religion in the Timurid and Safavid Periods", The Cambridge History of Iran, vol. 6, ed. P. Jackson and L. Lockhart (Cambridge: Cambridge University Press, 1986), 610-655.

7 S. Bashir, Messianic Hopes and Mystical Visions: The Nürbakhshìya between Medieval and Modern Islam (Columbia, SC: University of South Carolina Press, 2003), 98.

8 Quoted in ibid., 98-99.

9 See ibid., 97-102.

10 See ibid., $97-98$.

11 In using this term, I am borrowing an image used by Sarah Stroumsa in the different context of medieval Andalusian falsafah, to describe the mutual influence of Jewish and Muslim philosophers upon one another. See S. Stroumsa, "Thinkers of 'This Peninsula': Toward an Integrative Approach to the Study of Philosophy in al-Andalus", Beyond Religious Borders: Interaction and Intellectual Exchange in the Medieval Islamic World, ed. D.M. Freidenreich and M. Goldstein (Philadelphia, PA: University of Pennsylvania Press, 2011), 44-53.

12 Hodgson, Venture, 2:451.

13 See al-Jīlì, al-Insān, 119.

14 See ibid., 118-120.

15 See ibid., 129.

16 See ibid., 130.

17 Indeed, on numerous occasions in the chapters on the scriptures his Ibn 'Arabian Sufi metaphysics leads him to offer a more benevolent interpretation of the doctrines of the Jews and Christians than that found in mainstream Islamic thought. See e.g. ibid., 130:

They [namely, the Christians] are not among the obstinate (mu'änidīn), nor are they among those who have no master (mawlá), because it is the unbelievers (al-käfirīn) who have no master. For they are, in reality ('alá al-haqiqqah), in the right (muhiqqūn), because God - May He be exalted - is the reality of Jesus (haqīqat 'ìsá), and the reality of his mother (haqīqat ummihi), and the reality of the Holy Spirit (haqīqat al-rūh al-quds), indeed, the reality of everything (haqīqat kull shay').

18 'Abd al-Qādir in fact seems to have claimed these titles for himself. See al-Jīlānī, Dīwān, 163-164:

I am a shaykh, a righteous one, a Friend of God (anā shaykh wa-șālih wa-walīy)/I am the Pole and a model for mankind (anā quṭb wa-qudwah li-al-anām)/I am 'Abd al-Qādir, may my Time be glad/and my ancestor is Muștafá [namely, Muhammad], the mediator of mankind.

Certainly, his later followers viewed him as the Pole of his age. Thus the famous lexicographer al-Fayrūzābādī, for instance, who, it will be remembered, was in Yemen at the same time as al-Jīlī, wrote a book titled Rawdat al-nāzir fì manāqib al-ghawth 'Abd al-Qādir. See Y. Ziedan, Duwwāmāt al-tadayyun (Cairo: Dār al-Shurūq, 2013), 281. See also al-Tahānawī, Kashshāf, 1329.

19 It should be noted that the attribution of these discourses to 'Abd al-Qādir has been called into question. See W. Braune, $E I^{2}$, s.v. “'Abd al-Kāàir al-Dj̄̄lān̄̄”. What 
matters for our purposes, however, is that by al-Jîlī's time, "the 'Abd al-Kādir of legend" (in Braune's words), that is, the exponent of these Sufi ideas, was long established, and it was this legendary figure, therefore, that al-Jîli would have thought of as the 'real' 'Abd al-Qādir.

20 Al-Jīlānī, Dìwān, 206-216. See also Ziedan, Duwwāmāt, 279.

21 It should be noted, however, that Ibn 'Arabī engaged with the figure of "Abd al-Qādir, whom he held "in high esteem", naming him as one of the Poles, 'The Imam of his Age' (imām al- 'așr), 'The Leader of his Time' (sayyid waqtihi), a Friend of God, and one of the spiritual elite whom he calls al-malamiyyah (the People of Blame). See Abrahamov, Ibn al- 'Arabī, 152. In light of this, it is possible that al-Jîlī's view of "Abd al-Qādir was mediated through Ibn 'Arabī. Indeed, at one point in al-Insān al-kāmil he quotes 'Abd al-Qādir but cites a passage from Ibn 'Arabī's Futūhnāt as his textual source. See al-Jīlì, al-Insān, 128.

22 Al-Jīìi, al-Insān, 210.

23 Ibid., 207.

24 Annemarie Schimmel is therefore correct - though probably does not go far enough when she says that "Jīl $1 \overline{1}$... did his utmost to systematize the thoughts of Ibn 'Arabī, though at certain points he differed from him", Schimmel, Mystical Dimensions, 281.

25 An excellent first step in rectifying this is K. El-Rouayheb, Islamic Intellectual History in the Seventeenth Century: Scholarly Currents in the Ottoman Empire and the Maghreb (Cambridge: Cambridge University Press, 2015), esp. part III.

26 Padwick, Muslim Devotions, 138. See also ibid., 254-257, for prayers on "the precreation mystery of Muhammad".

27 See Hoffman, "Annihilation in the Messenger"; Addas, "At the distance" ". See also O. Ogunnaike, "Annihilation in the Messenger Revisited: Clarifications on a Contemporary Sufi Practice and its Precedents", Journal of Islamic and Muslim Studies 1, no. 2 (2016), 13-34. For advocates of the Neo-Sufism thesis, the eighteenth century witnessed the quest for mystical annihilation in God (fanā' fì Alläh) being replaced by the quest for mystical annihilation in the Messenger ( $f a n \bar{a}$ ' $f \grave{\imath}$ al-rasül), as well as the rejection of Ibn 'Arabian ideas. For more on this issue, see R.S. O'Fahey and B. Radtke, "Neo-Sufism Reconsidered", Der Islam 70 (1993), 52-87.

28 Perhaps with this in mind, Hodgson describes al-Jīli as "the most effective popularizer of Ibn-al-“Arabî's solutions”, Hodgson, Venture, 2:462.

29 See Moin, Millennial Sovereign; Binbaş, Intellectual Networks; Yilmaz, Caliphate Redefined; Markiewicz, Crisis of Kingship.

30 It should be noted in this regard that Azfar Moin, the pioneering scholar in this area, does not look at the transmission of ideas through texts (as I do), preferring to concentrate on material culture and ritual practice.

31 For al-Bosnawī's life and thought, see R. Hafizović, "A Bosnian Commentator on the Fusus al-hikam", Journal of the Muhyiddin Ibn 'Arabi Society 47 (2010), 87-107. As Noel Malcolm writes,

Most of the literary works of the Bosnian Muslims [during the Ottoman period] were written in Turkish, Arabic, or Persian. There are obvious reasons for this: some were writing in forms where the language was an inseparable part of the genre, such as the elaborate courtly poetry of the Persian tradition; some were dealing with subjects, such as philosophy, where an entire technical vocabulary was present in Arabic but lacking Serbo-Croat; and of course many were writing for readers outside of the Slav lands.

N. Malcolm, Bosnia: A Short History (London: Pan Books, 2002), 102. Both the second and third points apply to al-Bosnawī, whom Malcolm includes in his list of eight or nine "major writers" of Ottoman Bosnia, an indication of al-Bosnawī's significance within the intellectual history of the Bosnian nation. 
32 C. Brockelmann, History of the Arabic Written Tradition, tr. J. Lameer (Leiden; Boston, MA: Brill, 2018), Supplement 2:294, tells us of the existence of a manuscript of this versified work in Mosul.

33 Al-Bosnawī, Kitāb al-Qirá al-rūḥ̄, 6. See also ibid., 3.

34 Ibid., 2-3.

35 See R. Sellheim, $E I^{2}$, s.v. "al-Tahānawī”.

36 See e.g. al-Tahānawī, Kashshāf, 270-271, 281, 816, 1270, 1311-1312, 1746.

37 Ibid., 281.

38 Al-Tahānawī in fact does not cite from the Fuk $\bar{u} k$ directly, but rather from a passage quoted in 'Abd al-Raḥmān Jāmī’s commentary on the Fuṣuṣs.

39 On the Mawāqif, see Woerner-Powell, Another Road, 159 ff.

40 See Weismann, "God and the Perfect Human", 66-68.

41 Al-Jazā'irī, al-Mawāqif, 2:289, 1:228.

42 See Woerner-Powell, Another Road, 167.

43 See ibid., 163, 196, 203.

44 See Weisman, "God and the Perfect Man", 64.

45 See Woerner-Powell, Another Road, 163-164.

46 Al-Jazā’irī, al-Mawāqif, 1:58.

47 Ibid., 1:59.

$48 \mathrm{Ibn}$ 'Arabī also cites this hadith in the Futūhàt. See Chittick, Sufi Path of Knowledge, 241.

49 See al-Jî̀ī, al-Insān, 128.

50 For the significance of Ibn Jamīl to the Ibn 'Arabian Sufis of Yemen, see Knysh, Ibn 'Arabi, 236; Ziedan, 'Abd al-Karìm, 47; Ziedan, al-Fikr, 45-46; al-Jīlī, Ibdā', 36.

51 Al-Jazā'irī, al-Mawāqif, 1:59.

52 See Trimingham, Sufi Orders, 126; J. van Ess, "Libanesische Miszellen: 6: Die Yašruțīya", Die Welt des Islams 16, no. 1 (1975), 101-103; A. Bötcher, EI ${ }^{2}$, s.v. "Yashruțiyya".

53 Weisman, "God and the Perfect Man", 70.

54 On Fāṭimah al-Yashruțiyyah, see L. Cadavid, "Fatima al-Yashrutiyya: The Life and Practice of a Sufi Woman and Teacher", Voices of Islam, volume 1: Voices of Tradition, ed. V. Cornell (Westport, CT; London: Praeger, 2007), 175-200.

55 This term is translated by van Ess as "hiersein" - "being here".

56 Quoted in van Ess, "Libanesische Miszellen", 46-47.

57 See ibid., 47.

58 Ibid., 48.

59 See Iqbal, "The Doctrine". For a recent attempt to explain this article in light of Iqbal's involvement in contemporary philosophical debates, see F. Yilmaz, "Overcoming Nihilism Through Sufism: An Analysis of Iqbal's Article on 'Abd al-Karīm al-Jīlî”, Journal of Islamic Studies 41 (2018), 1-29.

60 See Iqbal, Development of Metaphysics, 116-133

61 See M. Iqbal, The Secrets of the Self (Asrár-i khudi): A Philosophical Poem, tr. R.A. Nicholson (London: Macmillan and Co. Limited, 1920), xii-xiv, xviii; F. Rahman, "Iqbal and Mysticism", Iqbal as a Thinker, ed. M.R. Siddiqi (Lahore: Sh. Muhammad Ashraf, 1944), 206-230; M. Siddiqi, "A Historical Study of Iqbal's Views of Sufism", Islamic Studies 5, no. 4 (1966), 411-427; A. Nur-ud-Din, "Attitude toward Sufism”, Iqbal: Poet-Philosopher of Pakistan, ed. M. Hafeez (New York; London: Columbia University Press, 1971), 288-300; A. Schimmel, "Mystic Impact of Hallaj", Iqbal: Poet-Philosopher of Pakistan, 310-324; M. Nazir-Ali, The Influence of Maulānā Jalāluddīn Rūmī on the Theology of 'Allāma Iqbāl (Doctoral thesis, University of Oxford, 1974); Hodgson, Venture, 3:347-349; M. Iqbal, The Reconstruction of Religious Thought in Islam, intr. J. Majeed (Stanford, CA: Stanford University Press, 2012), 119; M. Iqbal, Taking Issue \& Allah's Answer, tr. M. Dalvi (New Delhi: Penguin Books, 2012), xxi-xxii, 85; M.Q. Zaman, Islam in Pakistan: A History (Princeton, NJ: Princeton University Press, 2018), 196-197. 
62 Zaman, Islam in Pakistan, 197.

63 Iqbal, "The Doctrine," 78.

64 Iqbal, it should be noted, was heavily critical of Plato and his pernicious influence on 'pantheistic' Sufism. See Iqbal, Secrets of the Self, xxii-xxiii, 56-59; Nur-ud-Din, "Attitude", 292-294.

65 Iqbal, "The Doctrine", 96-97.

66 Ibid., 82.

67 Ibid., 97. According to Fazlur Rahman, Iqbal's study of al-Insān al-kāmil demonstrates "his bearings towards this aspect of esoteric philosophy. Iqbal's early works show very slight traces of this influence, which was to bear its most remarkable fruit much later in his poetic career." Rahman, "Iqbal and Mysticism", 229.

68 In the preface to Nicholson's English translation, there is a note here that reads: "Kor. ch. 23, v. 14: 'Blessed is God, the best of those who create."'

69 Iqbal, Secrets of the Self, xviii-xix.

70 Cf. Hodgson, Venture, 3:350.

71 See Chittick, Sufi Path of Knowledge, 22, 283-284; W. Chittick, Imaginal Worlds: Ibn al- 'Arabi and the Problem of Religious Diversity (Albany, NY: State University of New York Press, 1994), 23, 36, 45. Already Goldziher had recognised the importance of this motif as the "summum bonum" of Sufi thought. See Goldziher, Introduction, 21-22, note 23. It was also the subject of a long discussion by al-Ghazālī in his book on the 99 most beautiful names of God. See W. Chittick, "Worship", The Cambridge Companion to Classical Islamic Theology, ed. T. Winter (Cambridge; New York: Cambridge University Press, 2008), 218-236, 222.

72 Al-Qāshānī, Mu jam, 174.

73 Al-J̄̄lì, al-Insān, 156.

74 Cf. Marshall Hodgson's description of Iqbal's concept of khudī in Venture, 3:348: "The destiny to which each finite individual, each human being, was called was to be more and more like God: more and more uniquely individual, and therefore more and more creative."

75 Al-J̄ilì, al-Insān, 126.

76 Ibid., 152. See also ibid., 72.

77 M. Iqbal, Kulliyyāt-i Ash'ār-i Fārsī-yi Iqbāl-i Lāhūrī, ed. M. Darwīsh (Tehran: Sāzmān-i Intishārāt-i Jāv īdān, 1366 SH [= 1987/1988], 112-114; Iqbal, Secrets of the Self, xxvii-xxviii, 78-84.

78 Cf. Hodgson, Venture, 3:350: “As for the Șûfîs, so for Iqbâl, Muhammad was the prototype, in his universality and rationality, of the ultimate perfect man."

79 Iqbal, Kulliyyāt-i Ash'ār-i Fārsī, 196. For an alternative translation, see M. Iqbal, The Mysteries of Selflessness: A Philosophical Poem, tr. A.J. Arberry (London: J. Murray, 1953), 79.

80 Rahman, "Iqbal and Mysticism", 229.

81 Iqbal, Kulliyyāt-i Ash'ār-i Fārsī, 398-399. For an alternative English translation, see M. Iqbal, Javidname: Translated from the Persian with Introduction and Notes, tr. A.J. Arberry (London: Allen \& Unwin, 1966), 99.

82 Al-Jīlī, al-Kamālāt, 67.

83 See Izutsu, Sufism \& Taoism, 96, 256, 259; Chittick, Sufi Path of Knowledge, 113-114, 176, 211, 380.

84 Rahman, "Iqbal and Mysticism", 230.

85 On these works, see now F. Morrissey and R. Nettler, "Ibn Khaldūn on Sufism: A Story of Truth vs. Falsehood in Three Parts", Maghreb Review 44, no. 4 (2019).

86 Ibn Khaldūn, Shifā' al-sā'il wa-tahdhīb al-masā'il, ed. M. al-Ḥāfiz (Damascus: Dār al-Fikr, 1996), 107.

87 See Knysh, Ibn 'Arabi, 192.

88 Ibn Khaldūn, Shifā', 109; Ibn Khaldūn, Muqaddimah, 3:995. 
89 Ibn Khaldūn wrote the Shifä' 'between 1372 and 1374, and completed the first draft of the Muqaddimah in 1377, more than two decades before al-Jīli wrote al-Insān al-kāmil. For the dating of the Shifä', see Ibn Khaldūn, Ibn Khaldūn on Sufism: Remedy for the Questioner in Search of Answers (Shifā' al-Sä'il li-Tahdhīb al-Masā'il), tr. Y. Özer (Cambridge: Islamic Texts Society, 2017), xxvii-xxviii. For the Muqaddimah, see Ibn Khaldūn, The Muqaddimah, 1:1iii.

\section{Bibliography}

Abrahamov, Binyamin. Ibn al-'Arabī and the Sufis. Oxford: Anqa Publishing, 2014.

Addas, Claude. " 'At the Distance of Two Bows' Length or even Closer': The Figure of the Prophet in the Work of 'Abd al-Karīm al-Jīlì', Journal of the Muhyiddin Ibn 'Arabi Society 45 (2009), pp. 65-88, 46 (2009), pp. 1-26.

Amir-Moezzi, Mohammad A. The Divine Guide in Early Shi 'ism: The Sources of Esotericism in Islam. Translated by David Streight. Albany, NY: State University of New York Press, 1994.

Amir-Moezzi, Mohammad A. The Spirituality of Shi'i Islam: Beliefs and Practices. London: I.B. Tauris, 2011.

Amoretti, Biancamara S. "Religion in the Timurid and Safavid Periods", The Cambridge History of Iran, volume 6. Edited by Peter Jackson and Laurence Lockhart. Cambridge: Cambridge University Press, 1986, pp. 610-655.

Bashir, Shahzad. Messianic Hopes and Mystical Visions: The Nürbakhshīya between Medieval and Modern Islam. Columbia, SC: University of South Carolina Press, 2003.

Binbaş, İlker E. Intellectual Networks in Timurid Iran: Sharaf al-Dīn 'Alī Yazdī and the Islamicate Republic of Letters. Cambridge: Cambridge University Press, 2016.

Bosnawī, 'Abd Allāh. Kitāb al-qirá al-rūḥ̄ al-mamdūd li-al-aḍyāf al-wāridīn min marātib al-wujūd. Edited by 'Abd Allāh Qārțāl. Bursa, no publisher listed, 1996.

Bötcher, Annabelle. "Yashruțyya”, Encyclopaedia of Islam, second (new) edition.

Braune, Walther. “'Abd al-Ḳādir al-Djīlānī”, Encyclopaedia of Islam, second (new) edition.

Brockelmann, Carl. History of the Arabic Written Tradition. Translated by Joep Lameer. Leiden; Boston, MA: Brill, 2018.

Cadavid, Leslie. "Fatima al-Yashrutiyya: The Life and Practice of a Sufi Woman and Teacher", Voices of Islam, volume 1: Voices of Tradition. Edited by Vincent Cornell. Westport, CT; London: Praeger, 2007, pp. 175-200.

Chittick, William C. The Sufi Path of Knowledge: Ibn al- 'Arabi's Metaphysics of Imagination. Albany, NY: State University of New York Press, 1989.

Chittick, William C. Imaginal Worlds: Ibn al-'Arabī and the Problem of Religious Diversity. Albany, NY: State University of New York Press, 1994.

Daftary, Farhad. The Ismailis: Their History and Doctrines. Cambridge: Cambridge University Press, 2007.

El-Rouayheb, Khaled. Islamic Intellectual History in the Seventeenth Century: Scholarly Currents in the Ottoman Empire and the Maghreb. Cambridge: Cambridge University Press, 2015.

Goldziher, Ignaz. Introduction to Islamic Theology and Law. Translated by Andras and Ruth Hamori, with introduction and notes by B. Lewis. Princeton, NJ: Princeton University Press, 1981.

Hafizović, Rešid. "A Bosnian Commentator on the Fusus al-hikam", Journal of the Muhyiddin Ibn 'Arabi Society 47 (2010), pp. 87-107. 
Hodgson, Marshall. "How Did the Early Shî‘a Become Sectarian?" Journal of the American Oriental Society 75, no. 1 (1955), pp. 1-13.

Hodgson, Marshall. The Venture of Islam: Conscience and History in a World Civilization, in three volumes. Chicago, IL; London: University of Chicago Press, 1974.

Hoffman, Valerie. "Devotion to the Prophet and His Family in Egyptian Sufism", International Journal of Middle East Studies 24, no. 4 (1992), pp. 615-637.

Hoffman, Valerie. "Annihilation in the Messenger of God: The Development of a Sufi Practice”, International Journal of Middle East Studies 31, no. 3 (1999), pp. 351-369.

Hiibshī, 'Abd Allāh M. Al-Șüfiyyah wa-al-fuqahā' fì al-Yaman. Sanaa: Tawzī' maktabat al-jīl al-jadīd, 1976.

Ibn Khaldūn. The Muqaddimah: An Introduction to History, in three volumes. Translated by Franz Rosenthal. London: Routledge \& Kegan Paul, 1958.

Ibn Khaldūn. Shifā' al-sā'il wa-tahdhīb al-masā'il. Edited by Muhammad Muṭī' al-Hāāiẓ. Damascus: Dār al-Fikr, 1996.

Ibn Khaldūn. Muqaddimah, in three volumes. Edited by 'Alī 'Abd al-Wāḥid Wāfì. Cairo: Dār Nahdat Miṣr li-al-nashr, 2014.

Ibn Khaldūn. Ibn Khaldūn on Sufism: Remedy for the Questioner in Search of Answers (Shifā' al-Sā'il li-Tahdhīb al-Masā'il). Translated by Y. Özer. Cambridge: Islamic Texts Society, 2017.

Iqbal, Muhammad. The Development of Metaphysics in Persia: A Contribution to the History of Muslim Philosophy. London: Luzac \& Co., 1908.

Iqbal, Muhammad. The Secrets of the Self (Asrár-i khudi): A Philosophical Poem. Translated by Reynold A. Nicholson. London: Macmillan \& Co. Limited, 1920.

Iqbal, Muhammad. The Mysteries of Selflessness: A Philosophical Poem. Translated by Arthur J. Arberry. London: J. Murray, 1953.

Iqbal, Muhammad. Javidname: Translated from the Persian with Introduction and Notes. Translated by A.J. Arberry. London: Allen \& Unwin, 1966.

Iqbal, Muhammad. Kulliyyāt-i Ash'ār-i Fārsī-yi Iqbāl-i Lāhūrī. Edited by M. Darwīsh. Tehran: Sāzmān-i Intishārāt-i Jāv īdān, 1366 SH [=1987/1988].

Iqbal, Muhammad. The Reconstruction of Religious Thought in Islam. Introduced by Javed Majeed. Stanford, CA: Stanford University Press, 2012.

Iqbal, Muhammad. Taking Issue \& Allah's Answer. Translated by Mustansir Dalvi. New Delhi: Penguin Books, 2012.

Iqbal, Muhammad. "The Doctrine of Absolute Unity as Expounded by Abdul Karim Jilani", Speeches, Writings and Statements of Iqbal, in two volumes. Edited by Ahmad Shirwani. Lahore: Iqbal Academy Pakistan, 2015, pp. 77-97.

Izutsu, Toshihiko. Sufism \& Taoism: A Comparative Study of Key Philosophical Concepts. Berkeley, CA; London: University of California Press, 1984.

Jazā'irī, 'Abd al-Qādir. Al-Mawāqif al-rūhiyyyah wa-al-fuyūẹāt al-subūhiyyah, in two volumes. Edited by 'Āṣim al-Kayyālī. Beirut: Dār al-kutub al-'ilmiyyah, 2004.

J̄̄lānī, 'Abd al-Qādir. Dìwān Abd al-Qādir al-Jīlānī. Edited by Youssef Ziedan. Beirut: Dār al-J̄il, no date.

Jīlī, 'Abd al-Karīm. Al-Insān al-kāmil fì ma'rifat al-awākhir wa-al-awā'il. Edited by Șalāḥ ibn Muḥammad 'Uwayḍah. Beirut: Dār al-Kutub al-'ilmiyyah, 1997.

Jìlī, 'Abd al-Karīm. Al-Kamālāt al-ilāhiyyah fì al-șifāt al-muhammadiyyah. Edited by Sa 'īd 'Abd al-Fattāḥ. Cairo: 'Ālam al-fikr, 1997.

Jīlī, 'Abd al-Karīm. Ibdā' al-kitābah wa-kitābat al-'ibdā' ('ayn 'alá al-'ayniyyah: sharh mu 'āṣir li- 'ayniyyat al-imām al-șüfì 'Abd al-Karīm al-Jīlì) [=al-Nādirāt al-'ayniyyah]. Edited and commented on by Su'ād al-Ḥakīm. Beirut: Dār al-Burāq, 2004. 
Kamada, Shigeru. "Walāya in Fayḍ Kāshān̄̄”, Reason and Inspiration in Islam: Theology, Philosophy, and Mysticism in Muslim Thought. Edited by Todd Lawson. London: I.B. Tauris, 2005, pp. 455-468.

Knysh, Alexander. Ibn 'Arabi in the Later Islamic Tradition: The Making of a Polemical Image in Medieval Islam. Albany, NY: State University of New York Press, 1999.

Kohlberg, Etan. "Some Zaydī Views on the Companions of the Prophet", Bulletin of the School of Oriental and African Studies 39, no. 1 (1976), pp. 91-98.

Madelung, Wilferd. "Zaydi Attitudes to Sufism", Islamic Mysticism Contested. Edited by Frederick de Jong and Bernd Radtke. Leiden: Brill, 1999, pp. 124-144.

Malcolm, Noel. Bosnia: A Short History. London: Pan Books, 2002.

Markiewicz, Christopher. Crisis of Kingship in Late Medieval Islam: Persian Emigrés and the Making of Ottoman Sovereignty. Cambridge: Cambridge University Press, 2019.

Mayer, Toby and Wilferd Madelung. Avicenna's Allegory on the Soul: An Ismaili Interpretation. London: I.B. Tauris, 2015.

Moin, Azfar. The Millennial Sovereign: Sacred Kingship and Sainthood in Islam. New York: Columbia University Press, 2012.

Morrissey, Fitzroy. "An Introduction to 'Abd al-Karīm al-Jīlî̀'s Commentary on the Futūhāat", Maghreb Review 41, no. 4 (2016), pp. 499-526.

Morrissey, Fitzroy and Ron Nettler, "Ibn Khaldūn on Sufism: A Story of Truth vs. Falsehood in Three Parts", Maghreb Review 44, no. 4 (2019), pp. 403-430.

Nazir-Ali, Michael. The Influence of Maulānā Jalāluddīn Rūmī on the Theology of 'Allāma Iqbāl. Doctoral thesis, University of Oxford, 1974.

Nur-ud-Din, Abu Sayeed. "Attitude toward Sufism", Iqbal: Poet-Philosopher of Pakistan. Edited by Malik Hafeez. New York; London: Columbia University Press, 1971.

O'Fahey, Rex S. and Bernd Radtke. "Neo-Sufism Reconsidered", Der Islam 70 (1993), pp. 52-87.

Ogunnaike, Oludamini. "Annihilation in the Messenger Revisited: Clarifications on a Contemporary Sufi Practice and its Precedents", Journal of Islamic and Muslim Studies 1, no. 2 (2016), pp. 13-34.

Padwick, Constance. Muslim Devotions. Oxford: Oneworld, 1996.

Qāshānī, 'Abd al-Razzāq. Mu 'jam iṣtilāḥāt al-șūfiyyah. Edited by 'Abd al-'Āl Shāhīn. Cairo: Dār al-Manār, 1992.

Rahman, Fazlur. "Iqbal and Mysticism", Iqbal as a Thinker. Edited by M. Raziuddin Siddiqi. Lahore: Sh. Muhammad Ashraf, 1944, pp. 206-230.

Schimmel, Annemarie. "Mystic Impact of Hallaj", Iqbal: Poet-Philosopher of Pakistan. Edited by Malik Hafeez. New York: Columbia University Press, 1971, pp. 310-324.

Schimmel, Annemarie. Mystical Dimensions of Islam. Chapel Hill, NC: University of North Carolina Press, 1975.

Sellheim, Rudolf. “Al-Tahānawī”, Encyclopaedia of Islam, second (new) edition.

Siddiqi, Mazheruddin. "A Historical Study of Iqbal's Views of Sufism”, Islamic Studies 5, no. 4 (1966), pp. 411-427.

Stroumsa, Sara. "Thinkers of 'This Peninsula': Toward an Integrative Approach to the Study of Philosophy in al-Andalus", Beyond Religious Borders: Interaction and Intellectual Exchange in the Medieval Islamic World. Edited by David M. Freidenreich and Miriam Goldstein. Philadelphia, PA: University of Pennsylvania Press, 2011, pp. 44-53.

Tahānawī, Muḥammad. Kashshāf iștilāḥāt al-funūn. Edited by Luṭ̂ī 'Abd al-Badī', 'Abd al-Mun'im Husayn, and Amīn Khūlī. Cairo: al-Mu'assasah al-Mișrīyah al-'āmmah li-lta' līf wa-al-tarjamah wa-al-țibā' ah wa-al-nashr, 1963. 
Terrier, Mathieu. "Le Mahbûb al-qulûb de Quṭb al-Dîn Ashkevarî: Une œuvre méconnue dans l'histoire de l'histoire de la sagesse en islam", Journal Asiatique 298, no. 2 (2010), pp. 345-387.

Trimingham, J. Spencer. The Sufi Orders in Islam. Oxford: Clarendon Press, 1971.

van Ess, Josef. "Libanesische Miszellen: 6: Die Yašruțīya”, Die Welt des Islams 16, no. 1 (1975), pp. 101-103.

Weismann, Itzchak. "God and the Perfect Man in the Experience of 'Abd al-Qadir alJaza'iri”, Journal of the Muhyiddin Ibn 'Arabi Society 30 (2001), pp. 55-72.

Woerner-Powell, Tom. Another Road to Damascus: An Integrative Approach to 'Abd al-Qādir al-Jazā'irī. Berlin; Boston, MA: Walter de Gruyter, 2017.

Yilmaz, Feyzullah. "Overcoming Nihilism Through Sufism: An Analysis of Iqbal's Article on 'Abd al-Karīm al-Jîlı’”, Journal of Islamic Studies 41 (2018), pp. 1-29.

Yilmaz, Hüseyin. Caliphate Redefined: The Mystical Turn in Ottoman Political Thought. Princeton, NJ: Princeton University Press, 2018.

Zaman, Muhammad Qasim. Islam in Pakistan: A History. Princeton, NJ: Princeton University Press, 2018.

Ziedan, Youssef. 'Abd al-Karìm al-Jīlī: faylasūf al-șüfiyyah. Cairo: al-Hay'ah al-Mișriyyah 'āmmah li-l-kitāb, 1988.

Ziedan, Youssef. Al-Fikr al-șūfì 'ind 'Abd al-Karīm al-Jūlī. Cairo: Dār al-Amīn, 1998.

Ziedan, Youssef. Duwwāmāt al-tadayyun. Cairo: Dār al-Shurūq, 2013. 